\title{
Evaluation of A Marketing Strategy Based on The Concept of Virtual Energy Audit
}

\author{
Goutham Kumar Reddy Challa \\ West Virginia University, gc0021@mix.wvu.edu
}

Follow this and additional works at: https://researchrepository.wvu.edu/etd

Part of the Energy Systems Commons, and the Marketing Commons

\section{Recommended Citation \\ Challa, Goutham Kumar Reddy, "Evaluation of A Marketing Strategy Based on The Concept of Virtual Energy Audit" (2019). Graduate Theses, Dissertations, and Problem Reports. 3805. \\ https://researchrepository.wvu.edu/etd/3805}

This Problem/Project Report is protected by copyright and/or related rights. It has been brought to you by the The Research Repository @WVU with permission from the rights-holder(s). You are free to use this Problem/Project Report in any way that is permitted by the copyright and related rights legislation that applies to your use. For other uses you must obtain permission from the rights-holder(s) directly, unless additional rights are indicated by a Creative Commons license in the record and/ or on the work itself. This Problem/Project Report has been accepted for inclusion in WVU Graduate Theses, Dissertations, and Problem Reports collection by an authorized administrator of The Research Repository @ WVU. For more information, please contact researchrepository@mail.wvu.edu. 
Evaluation of A Marketing Strategy Based on The Concept of Virtual Energy Audit.

Goutham Kumar Reddy Challa

Problem Report submitted

to the Benjamin M. Statler College of Engineering and Mineral Resources

at West Virginia University

in partial fulfillment of the requirements for the degree of

Master of Science in

Industrial Engineering

Ashish D. Nimbarte, Ph.D., Chair

Bhaskaran Gopalakrishnan, Ph.D., P.E.

Kenneth R. Currie, Ph.D., P.E.

Department of Industrial and Management Systems Engineering

Morgantown, West Virginia

2019

Keywords: Virtual Energy Audits, Energy Efficiency, Marketing

Copyright 2018 Goutham Kumar Reddy Challa 


\section{ABSTRACT \\ Evaluation of A Marketing Strategy Based on The Concept of Virtual Energy Audit.}

\section{Goutham Kumar Reddy Challa}

With the growing world population and efforts to bring better energy access to the people, energy needs of the world are expected to grow in the coming years. Given the limited availability of non-renewable resources, there has been a mounting consensus among the users and the stakeholders to utilize the available energy in the most efficient way by implementing various methods like use of advanced technologies, source reduction, behavioral changes, etc.

Energy efficiency in general is considered as a win-win scenario for all the users and/or stakeholders involved as it not only lowers the base load for power generating companies, but it also helps in reducing costs to the customers, emission of greenhouse gases and dependence on the fossil fuels. Energy audit by qualified professionals is a first logical step towards improving energy efficiency. Traditional methods to market energy audit include providing a leaflet or by word of mouth. However, such methods are often generic and ambiguous, and are not specific to the business/facility involved. In this study, the objective was to evaluate effectiveness of a virtual energy audit tool as a marketing strategy in comparison to the traditional leaflet-based marketing approach.

We identified the potential Energy Conservation Measures (ECM) and used a virtual energy audit tool to estimate the cost and energy savings for facilities based on publicly available data. The estimated savings were used as a selling point to market the energy audits. A survey study was conducted using a sample size of 200. Results of the survey study were inconclusive due to low response rate $(\sim 10 \%)$. However, some trends were observed indicating that virtual energy audit may positively influence facility's decision to request an energy audit. 


\section{ACKNOWLEDGEMENTS}

I would like to express my sincere gratitude to Dr. Ashish D. Nimbarte, for his continued support and encouragement during my research work and graduate studies. His inspiration, timely suggestion with kindness, enthusiasm and energy have enabled me to complete my problem report.

I would like to thank Dr. Bhaskaran Gopalakrishnan for being a constant source of support throughout my graduate studies and research. As a seasoned teacher, Dr. Gopala's teachings in the energy efficiency field have expanded my horizons and opened doors to many exciting opportunities.

I would also like to thank Dr. Kenneth R. Currie for his advice and support.

Finally, I thank God, my family and friends for their constant support. 


\section{Table of Contents}

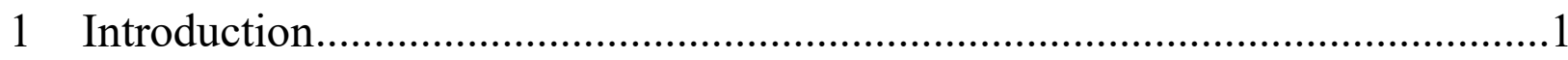

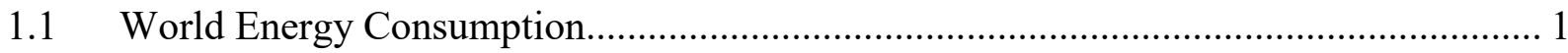

$1.2 \quad$ Alternate forms of energy …………………......................................................... 1

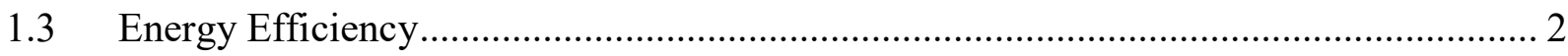

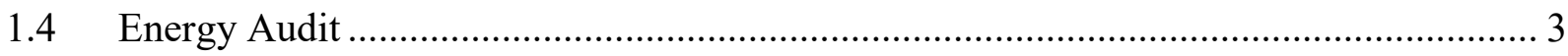

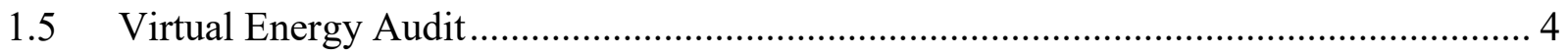

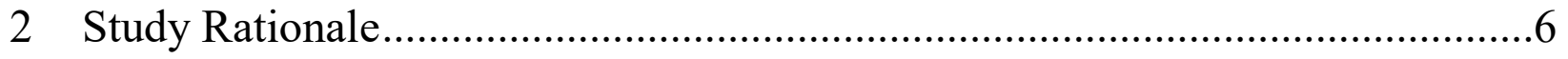

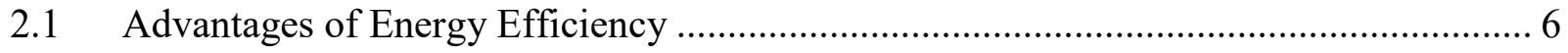

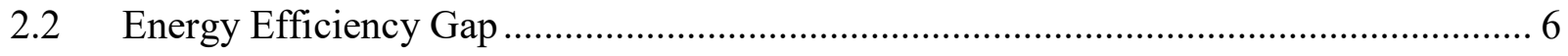

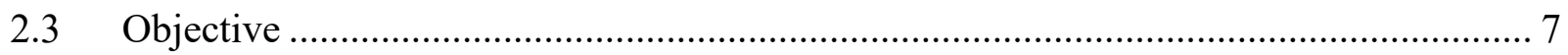

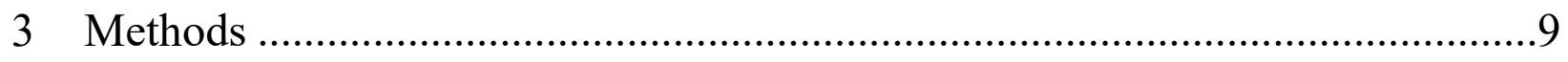

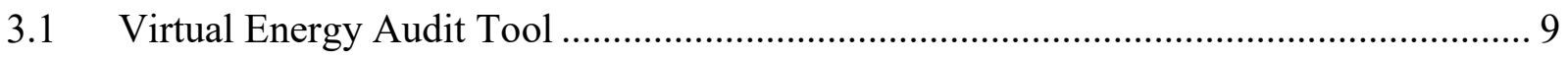

3.1.1 Commercial Virtual Energy Audit Tool .......................................................... 10

3.1.2 Industrial Virtual Energy Audit Tool................................................................. 38

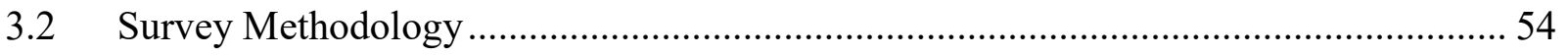

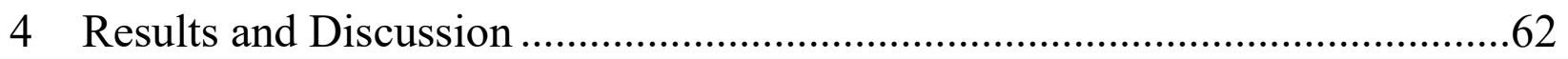

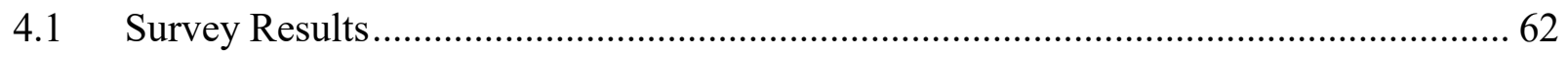




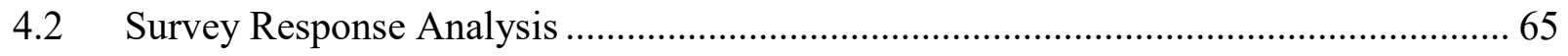

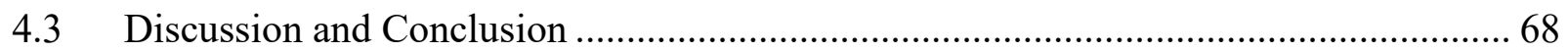

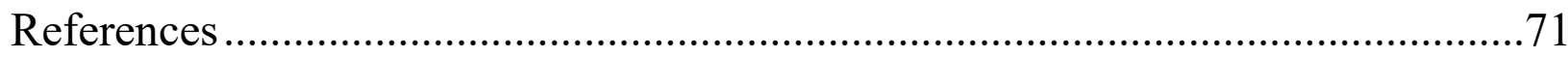

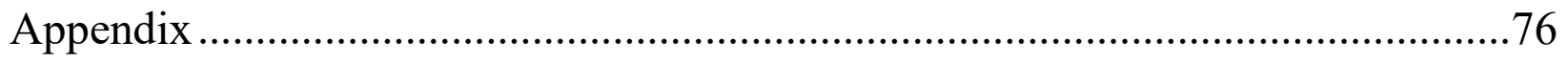




\section{Table of Figures}

Figure 1.1: World Energy Consumption in Mtoe by Source [1] …....................................... 2

Figure 3.1: U.S. Energy Consumption by End Use Sector [15] ............................................ 9

Figure 3.2: U.S. Commercial Buildings Energy Consumption by End Use [17] ........................ 10

Figure 3.3: LMC Lighting Technology Classification [18] ..................................................... 14

Figure 3.4: GUI for the commercial Virtual Energy Audit program........................................... 32

Figure 3.5: Output provided by the commercial Virtual Energy Audit program. ........................ 33

Figure 3.6: ARC Codes Format on IAC Website [27]............................................................. 43

Figure 3.7: Data Model for Industrial Virtual Audit tool .......................................................... 45

Figure 3.8: Industrial Virtual Energy Audit Tool Inputs ........................................................... 52

Figure 3.9: Industrial Virtual Energy Audit Tool Output ........................................................... 53

Figure 3.10: Locations Covered by the Survey .................................................................... 59

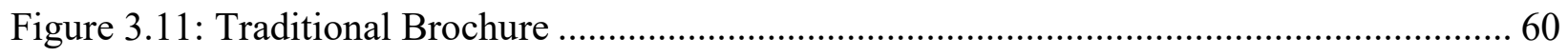

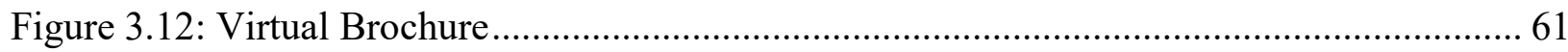

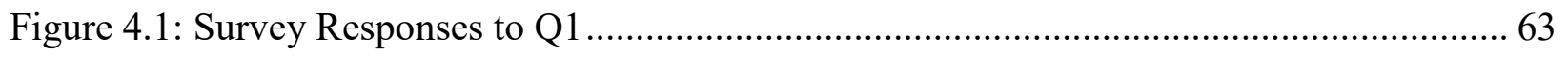

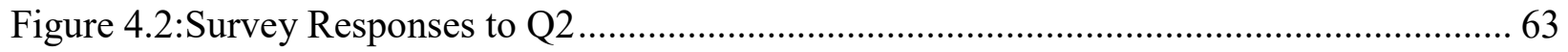

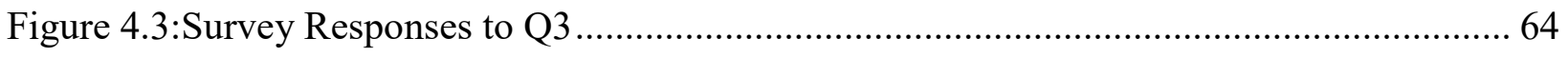

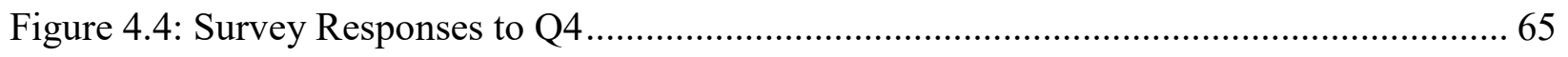

Figure 4.5:Survey Responses After Reading the Brochure. ...................................................... 66 


\section{Table of Tables}

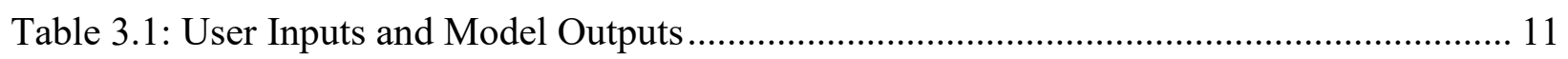

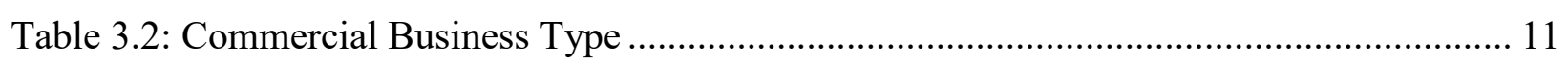

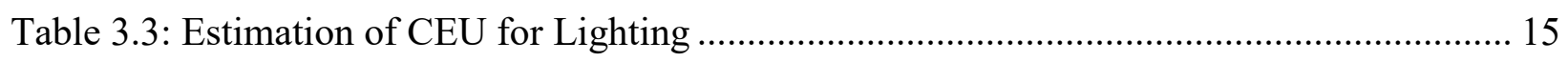

Table 3.4: Lighting Technology Distribution by Commercial Building Type in 2015 [18] ........ 16

Table 3.5: Lighting Electricity Use by Commercial Buildings in 2015 [18]............................... 17

Table 3.6: Total floorspace and lit floorspace by lighting type and Commercial Building Type [19]

Table 3.7: Average Lighting Wattage by Commercial Building Type in 2015 [18].................... 18

Table 3.8: Energy Intensity by the End Use by Climate Region [23], [24]................................. 24

Table 3.9: Natural gas consumption and conditional energy intensities (Btu) by end use [24] ... 29

Table 3.10: Natural gas consumption intensities by Climate Region [25] .................................. 29

Table 3.11: Electricity Consumption Intensities by Commercial Building Type [26] ................. 31

Table 3.12: Energy Cost Savings for a Commercial Facility ……………………....................... 32

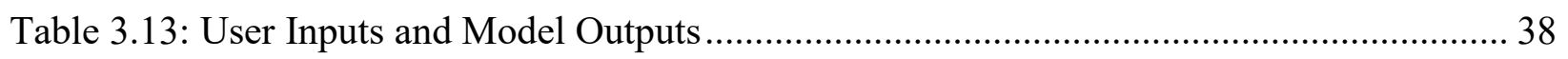

Table 3.14: Sample IAC Database Assessment Recommendation Code (ARC) system

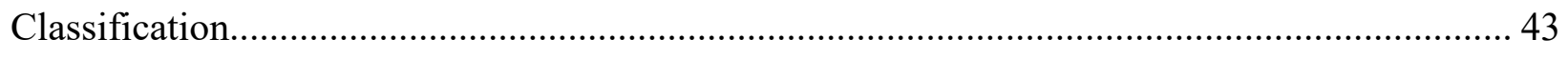

Table 3.15: Energy Cost Savings for an Industrial Facility........................................................ 51

Table 3.16: Two Types of Packages Used for Conducting Survey Study.................................... 54

Table 3.17: Comparison of Leaflet Methods and Virtual method Mail Packet............................. 57

Table 3.18: Distribution of Surveys by Marketing Method and Business Type …….................... 58

Table 4.1: Survey Reponses of Participants who have Answered No for Q3 ………….............. 67 


\section{Introduction}

\subsection{World Energy Consumption}

In 2017, world has consumed 13,511 Million tons oil equivalent (Mtoe) of energy which is $16.59 \%$ more in comparison to consumption of 11,588 Mtoe in 2007 [1]. With the growing world population, development activities and efforts to bring better energy access to the people around

the world, energy needs of the world are expected to grow in the coming years. As energy is considered a critical strategic and security component for a country, countries around the world have started looking for alternate forms of energy.

\subsection{Alternate forms of energy}

Primary source of energy in the world currently is fossil fuels. Nearly, $85.18 \%$ of total world energy in 2017 has come from non-renewable sources like coal, oil and natural gas [1]. Given the limited availability of these non-renewable resources, and the growing need for energy across the world, alternate forms of energy sources like Solar, Wind, Geo-thermal etc. have gained traction.

Apart from looking for alternate energy sources, utilizing the available energy in the most efficient way i.e. to get more output from a given input by various methods like advanced technologies, source reduction, behavioral changes etc., has also been adopted as an important strategy to overcome the current energy resources scarcity. The International Energy Agency (IEA) in its new policy scenario estimates that the developing economies would push up global energy demand by more than a quarter by 2040 in comparison to 2017. If it were not for continued improvements in energy efficiency and their implementation, global energy demand would be around twice as large by 2040 compared to 2017 [2]. The U.S public policy at state and federal level are also encouraging 
energy efficiency by adopting legislations like Michigan Senate Bill 438 (2016), Maryland House Bill 514 and Senate Bill 184 (2017) etc., at state level [3] and, The Energy Policy Act of 2005 [4], The Energy Independence and Security Act of 2007 (H.R.6) [4] etc., at federal level.

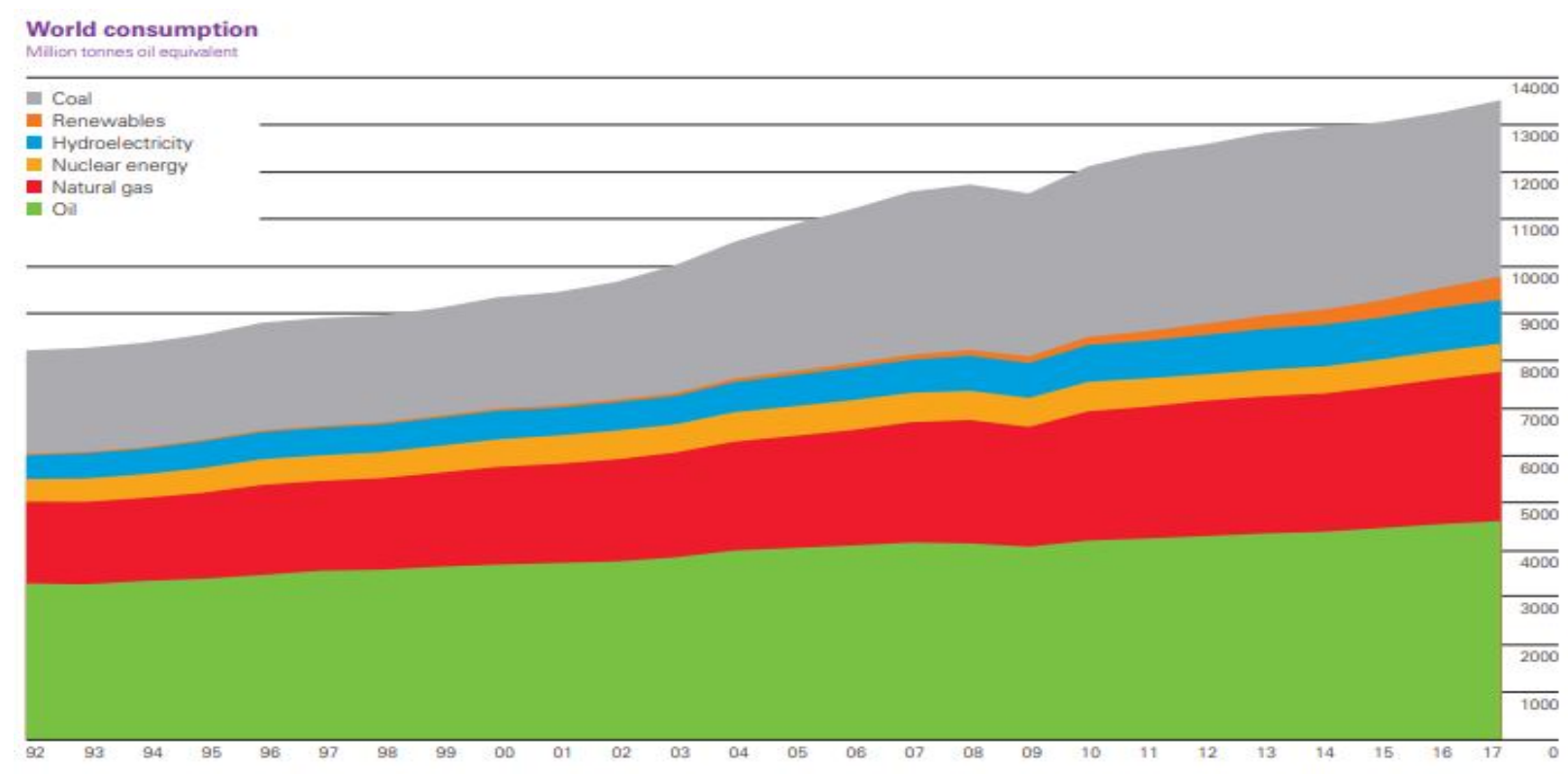

Figure 1.1: World Energy Consumption in Mtoe by Source [1]

\subsection{Energy Efficiency}

Efficiency in simple terms is defined as the ratio of output to input. Energy efficiency can be defined as to get more energy output with the given energy input. For example, to produce 2,000 lumens, a Light Emitting Diode (LED) bulb may consume 10 watts, whereas a florescent bulb may consume 25 watts. So, LED is considered as energy efficient when compared to a florescent bulb. Energy conservation can be defined as conserving energy by changing occupant/operator behaviors, methods of operation etc. Switching off a light bulb, HVAC temperature setback can be examples of behavioral change. Operating a boiler at a stoichiometrically optimal Air to Fuel ratio to avoid excess fuel burning can be an example of operation methodology. It should be noted 
that throughout this study terms energy efficiency and energy conservation measures are used interchangeably.

\subsection{Energy Audit}

For a business or a facility to operate efficiently in terms energy, the best way is to understand the energy profile and energy foot print of the facility to identify any opportunities for saving energy. One of the ways this can be done is to do an energy audit of the facility. American Council for Energy-Efficient Economy (ACEEE) defines energy audit as a thorough accounting of the energy use of a building or a facility [5].

A traditional energy audit is performed by visiting the facility to understand the nature of processes, energy consumption equipment, etc. and spending time ranging from few hours to few days to understand operations and collect data depending on the level of the energy audit to recommend energy conservation measures. Traditional energy audits are time consuming and requires active participation from the facility personnel, sometimes in order to collect the data facilities operations may have to be interrupted. The American Society of Heating, Refrigerating and Air-Conditioning Engineers (ASHRAE) categories energy audits in to three levels, Level I, Level II and Level III.

ASHRAE level I audit is the basic of all three types of energy audits. Level I audit is a simple walk through energy audit which aims to understand energy consumption of the facility and identify the low hanging energy conservation measures present at the facility.

ASHRAE level II energy audit is defined as an engineering analysis audit which aims to identify no-cost and low-cost opportunities, and provide Energy Conservation Measures in line with the 
facilities' financial plans, level II audits include an in-depth analysis of energy costs, energy usage and building characteristics and a more refined survey of how energy is used in the facility [6].

ASHRAE level III energy audit is referred as an investment grade energy audit which aims to provide solid recommendations and financial analysis for major capital investments. In addition to Level I and Level II activities, Level III audits include monitoring, data collection and engineering analysis [6].

\subsection{Virtual Energy Audit}

With growth of technology, advent of novel sensors, wireless connectivity and the availability of computing power many things have become "online" or "virtual", ranging from shopping to experiencing the adventure sports, energy audits are no exception.

A virtual energy audit is a method to recommend energy conservation measures without physically visiting the location but just by analyzing the electrical interval data, gas bills, address of the building etc. [7]. Virtual energy audit techniques have also been used to analyze the publicly available large scale datasets to predict residential energy consumption, energy efficiency parameters and savings potential, and to develop effective energy efficiency strategies for utilities and policy makers [8].

There are many energy tools developed by various agencies like Department of Energy (D.O.E), Environmental Protection Agency (E.P.A) etc., to help with developing energy profile and benchmarking of industrial and commercial facilities. Energy Performance Indicator Tool (EnPI), Energy Footprint Tool, Plant Energy Profiler, Scout etc. are few examples.

The Energy Performance Indicator Tool (EnPI) is a regression analysis-based tool developed by U.S. Department of Energy's Advanced Manufacturing Office (AMO) to help commercial and 
industrial facilities to help establish a normalized energy consumption baseline taking into account numerous variables like weather, production etc. [9]. EnPI tool requires monthly energy consumption data of the facility as input.

Energy Footprint Tool developed by the U.S. Department of Energy helps facilities to track their energy consumption, factors related to energy use, and significant energy end-uses [10]. The Plant Energy Profiler (PEP) tool is provided by the U.S. Department of Energy to help industrial plants identify potential energy and cost savings. PEP determines the potential savings present at an industrial facility for various energy systems by asking a series of questions about the setup, operating parameters, and maintenance methods which are specific to the facility [11].

Scout is a software program developed by D.O.E. to help estimate the impacts of various energy conservation measures (ECMs) in the U.S. residential and commercial building sectors [12]. Tools like energy star portfolio manager were developed to assist with the energy benchmarking of commercial and residential facilities.

For the purposes of this study, Virtual Energy Audit is defined as a tool that can remotely estimate potential energy and dollar saving opportunities for a facility, i.e., without physically visiting the location. 


\section{Study Rationale}

\subsection{Advantages of Energy Efficiency}

Energy efficiency in general is considered as a win-win scenario for all the stakeholders involved as it would lower base load for power generating companies and helps to circumvent building new power plants, helps in reducing the energy costs for the customers, reduces dependence on fossil fuels, thereby reducing greenhouse gases.

Energy efficiency helps the facility to reduces their energy footprint, thereby reducing its carbon

footprint. Reducing energy consumption sometimes leads to help facilities attain Energy Star ${ }^{\circledR}$ or the LEED certifications helping businesses to build an image of a "green" or an environmentally conscious business, which, these days is seen as a positive factor for a business in the eyes of the customers.

Apart from the environmental benefits, energy efficiency provides economic and productivity benefits. Energy efficiency reduces the energy costs thereby reducing the operating costs for business, and energy efficient equipment often uses latest technologies and therefore offer more reliability, reduced downtime and maintenance, and longer equipment life. Energy efficiency investments generally offer attractive rate of return and good payback on investment. Energy efficiency investments in the industrial sector had an average payback period of around one year [13] [14].

\subsection{Energy Efficiency Gap}

As noted, despite of the economic and environmental benefits, the market penetration of energy efficiency strategies is on the lower side. The slow diffusion of the energy efficiency is described 
in the literature by various names like energy paradox, energy efficiency gap, energy efficiency paradox etc.

Energy paradox is defined as the gradual diffusion of apparently cost-effective energy efficient technologies in to the market [15]. Energy Efficiency gap is defined as the gap between the current energy use and the optimal energy use [16]. Energy efficiency paradox (or energy efficiency gap) is defined as, "although energy conservation and efficiency seem to present clear economic and environmental advantages, the level of investment in them does not reach the levels which would correspond to such benefits" [17].

Reasons for slow adaption of energy efficiency in the residential sector have found theoretical evidence pointing to operational cost, product pricing, product variety in the market, effectiveness of investments etc. among possible causes [18]. One more important factor contributing to the energy efficiency gap might be the imperfect information regarding potential investment opportunities available - meaning people or managements often times do not realize the potential of the energy efficiency investment opportunities present at their facility [19].

A paper analyzing the Industrial Assessment Center database found that, managers at industrial facilities miss out on many profitable energy saving opportunities and the "returns for the unrealized opportunities (i.e. energy conservation measures) are higher than one of the most expensive sources of funds available to managers" [14].

\subsection{Objective}

From the literature we have seen that the energy efficiency penetration in the US is not at the levels it should have been. Working at the Industrial Assessment Center and interacting with the local commercial and industrial facilities, we have experienced that the customers are unwilling to pay 
a small amount of fee to get an energy audit of the facility, though the monetary and environmental benefits of the energy audit generally outweigh the cost of the energy audit. It is our understanding that the facilities often do not realize the potential of the energy and cost savings opportunities that can result from an energy audit. One of the reasons for this can be the way in which the energy audit is marketed to the customer.

Traditionally an energy audit is marketed by providing a leaflet or by word of mouth explaining the benefits of the energy efficiency, which often times are generic and ambiguous, and are not specific to the type of the business or the facility. In this study, we first try to identify the potential Energy Conservation Measures (ECM) and use a virtual energy audit tool to estimate the cost and energy savings for a commercial or an industrial facility based on the publicly available data like the type of the business, operating hours, location etc., and use this estimated savings as a selling point to market the energy audit. The objective is to see whether utilizing the results from a virtual energy audit tool as a marketing strategy will be any effective in comparison to the traditional marketing approach to encourage businesses to get an energy audit done. 


\section{Methods}

The objective of this study was achieved by using a three-step approach. First, to build a virtual energy audit tool to estimate the potential energy and dollar savings for a given facility. Second, to use the results from the virtual energy audit tool as marketing strategy to encourage businesses to get an energy audit done. Third, to compare virtual energy audit marketing strategy with traditional marketing strategy, i.e., to use a generalized brochure to encourage facility to get an audit done.

\subsection{Virtual Energy Audit Tool}

Commercial and Industrial sectors are the primary focus of this study. In 2017, U.S. commercial and industrial sectors have consumed $32 \%$ and $18 \%$ of the total energy, respectively and contributed to the half of the energy consumption.

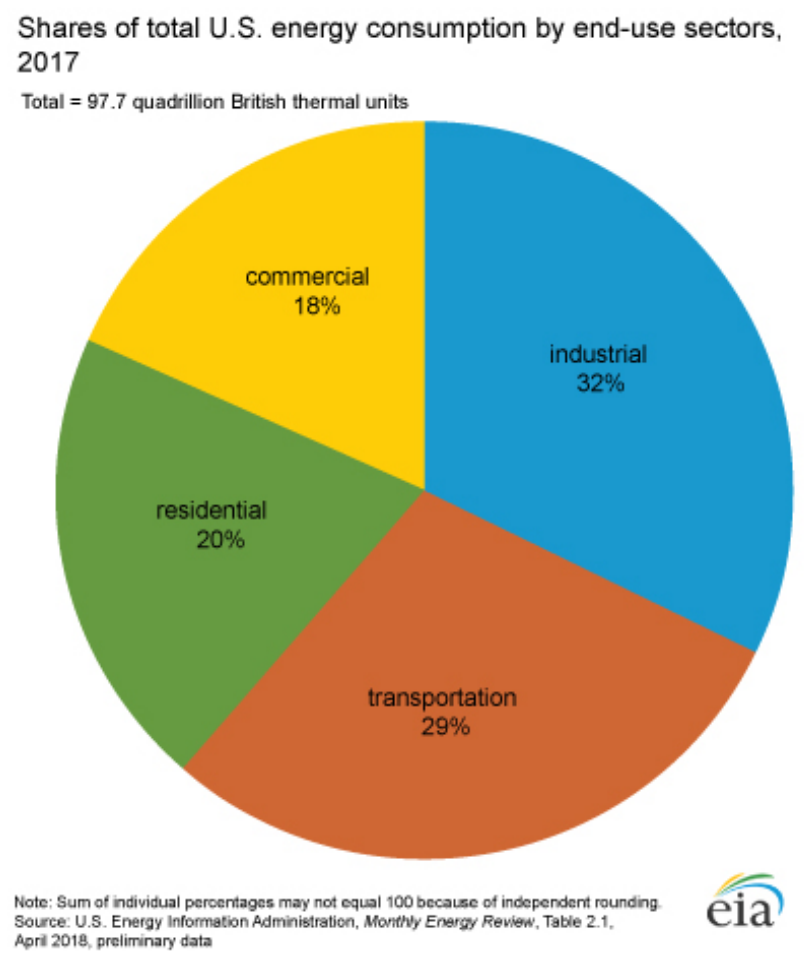

Figure 3.1: U.S. Energy Consumption by End Use Sector [20] 


\subsubsection{Commercial Virtual Energy Audit Tool}

Commercial is defined as, "any building that is neither residential (used as a dwelling for one or more households), manufacturing/industrial (used for processing or procurement of goods, merchandise raw materials or food), nor agricultural (used for the production, processing, sale, storage, or housing of agricultural products, including livestock). At least 50 percent of the floorspace must be used for purposes other than these.’'[21]

Lighting, HVAC (Heating, Ventilation, and Air Conditioning), and hot water heaters are the three major energy systems that were considered for developing energy conservation measures. These three energy systems were considered because they are the most common energy systems present across various businesses and were the major energy consuming equipment's in the commercial buildings.

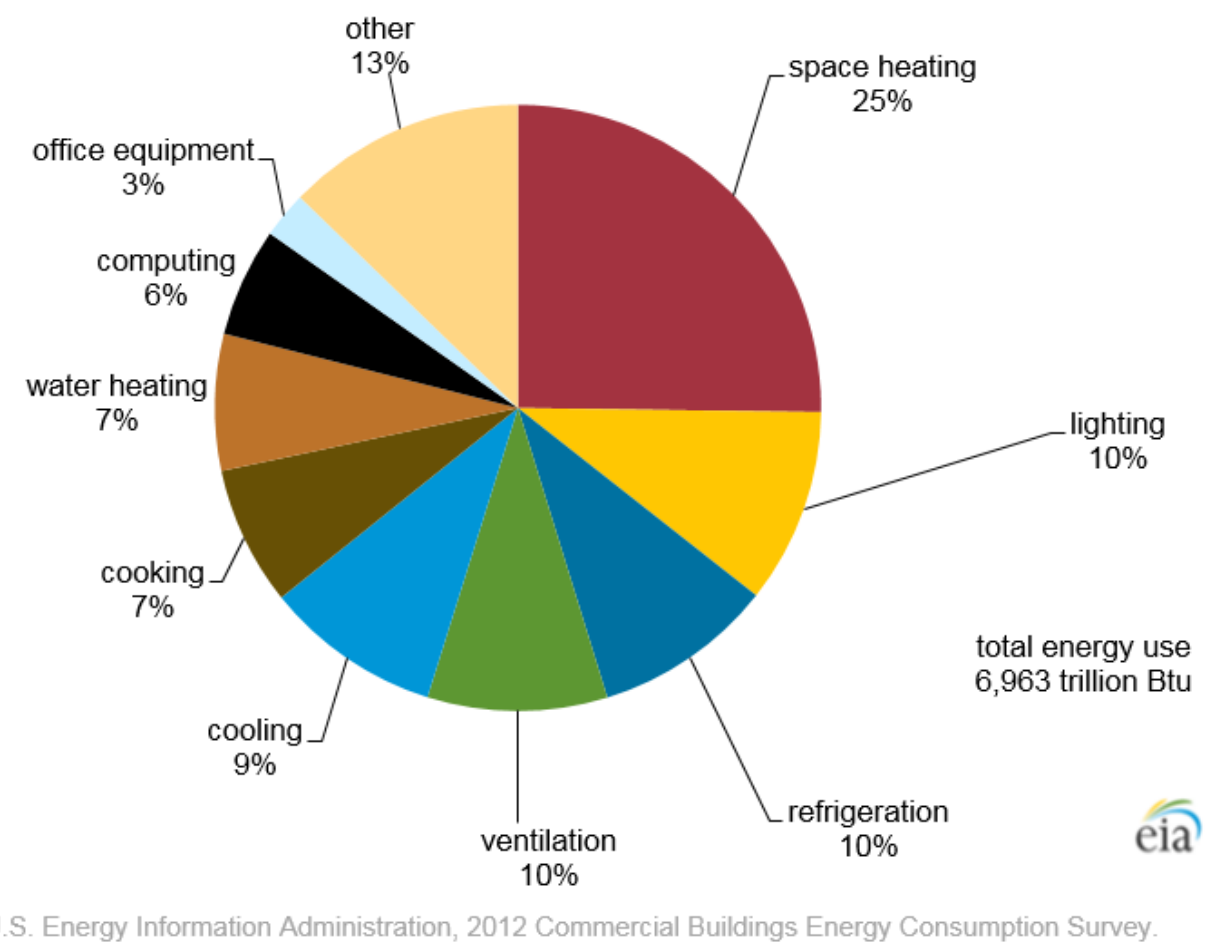

Figure 3.2: U.S. Commercial Buildings Energy Consumption by End Use [22] 


\subsubsection{User Inputs and Model Outputs}

Table 3.1: User Inputs and Model Outputs

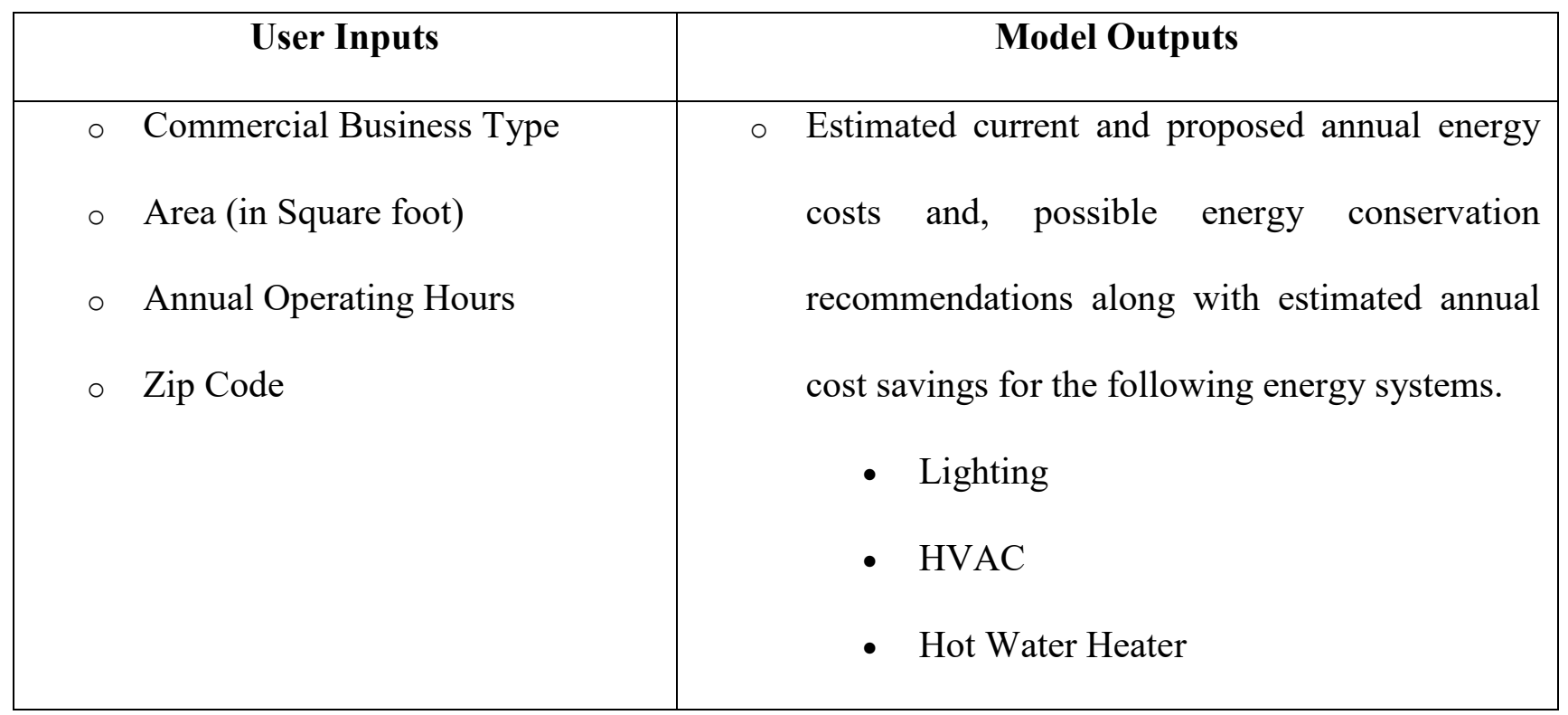

\section{Commercial Business Type:}

Commercial business type is the one of the inputs for the commercial virtual energy audit tool, with various options to select from as shown in Table 3.2. For detailed definitions of the businesses listed in Table 3.2 please see please see Appendix A-1.

Table 3.2: Commercial Business Type

\begin{tabular}{|c|c|c|}
\hline Education & Office & Service \\
\hline Food sales & Public assembly & Warehouse and storage \\
\hline Food service & Public order and safety & Other \\
\hline Health care & Religious worship & \\
\hline Lodging & Retail (other than mall) & \\
\hline
\end{tabular}




\section{Area:}

Area is defined as, "all the area enclosed by the exterior walls of a building, both finished and unfinished, including indoor parking facilities, basements, hallways, lobbies, stairways, and elevator shafts"'[21]. Area must be entered in square foot.

\section{Annual Operating Hours:}

Annual operating hours are defined as the total no. of hours the facility is doing its primary operation, excluding any periods of maintenance, when the facility is not occupied etc.

\section{$\underline{\text { Zip Code: }}$}

Zip or postal code of the area in which the facility is operating.

\subsubsection{Energy Systems:}

Once the user has provided the required inputs, the model estimates the values for annual energy and dollar values for existing and proposed scenarios.

Energy systems considered for developing energy conservation measures are
○ Lighting
○ Heating, Ventilation, and Air Conditioning (HVAC)
○ Hot Water Heaters

As an example, an imaginative facility with following characteristics is considered throughout this section:

- Commercial Business Type : Food Service

○ Area (in Sq. Ft) : $\quad$ 5,000 Sq. Ft.

○ Annual Operating Hours : : 3,060 hrs/year 
$\circ$ Zip Code $\quad: 26505$

\subsection{Lighting:}

Lighting is the most common type of energy systems which is present almost in all facilities irrespective of the type of business, and good light is a pre-requisite for creating a functional environment. Lighting is the second largest consumer of energy in the commercial buildings contributing $10 \%$ of the total energy consumption [22]. 2015 U.S. Lighting Market Characterization (LMC) survey by the Department of Energy estimates that the $40 \%$ of the total lighting electricity is consumed by the commercial sector [23].

Light can be produced from energy in many ways, early humans have used fire, candles, gas lamps etc. as the source of light. One of the early technologies to produce light with electricity was incandescent bulb. Incandescent bulb produces light through means of a heated element powered by electricity. As technology and science have progressed, ways of producing light have become more versatile and better. Most common lighting technologies that we see in everyday life are florescent lamps, high intensity discharge lamps, metal halides, light emitting diodes (LED) etc. For the purpose of this study it is assumed that the lighting in a given facility is powered by electricity.

2015 U.S. Lighting Market Characterization Survey provides good estimates to understand the current state of lighting technologies and the penetration of these technologies and their adaption in the U.S. market. LMC also provides the energy use estimates and provides detailed inventory of different lighting technologies by different sectors and sub sectors. As this section deals with only commercial sector, so only those sections of the report which are relevant to this section are 
considered and presented from LMC. For different types of lighting technology classifications in the LMC refer to Figure 3.3.

To make it consistent across various data sets required for building the tool, few modifications have been made to the sub sectors of the LMC survey. Sub sector Offices (Non-medical) is renamed as office. Sub sectors Health care - Inpatient and Health care - outpatient are combined as Health care, and the average of the values of two sub sectors is taken to get the estimates for the newly created entry i.e. Health Care.
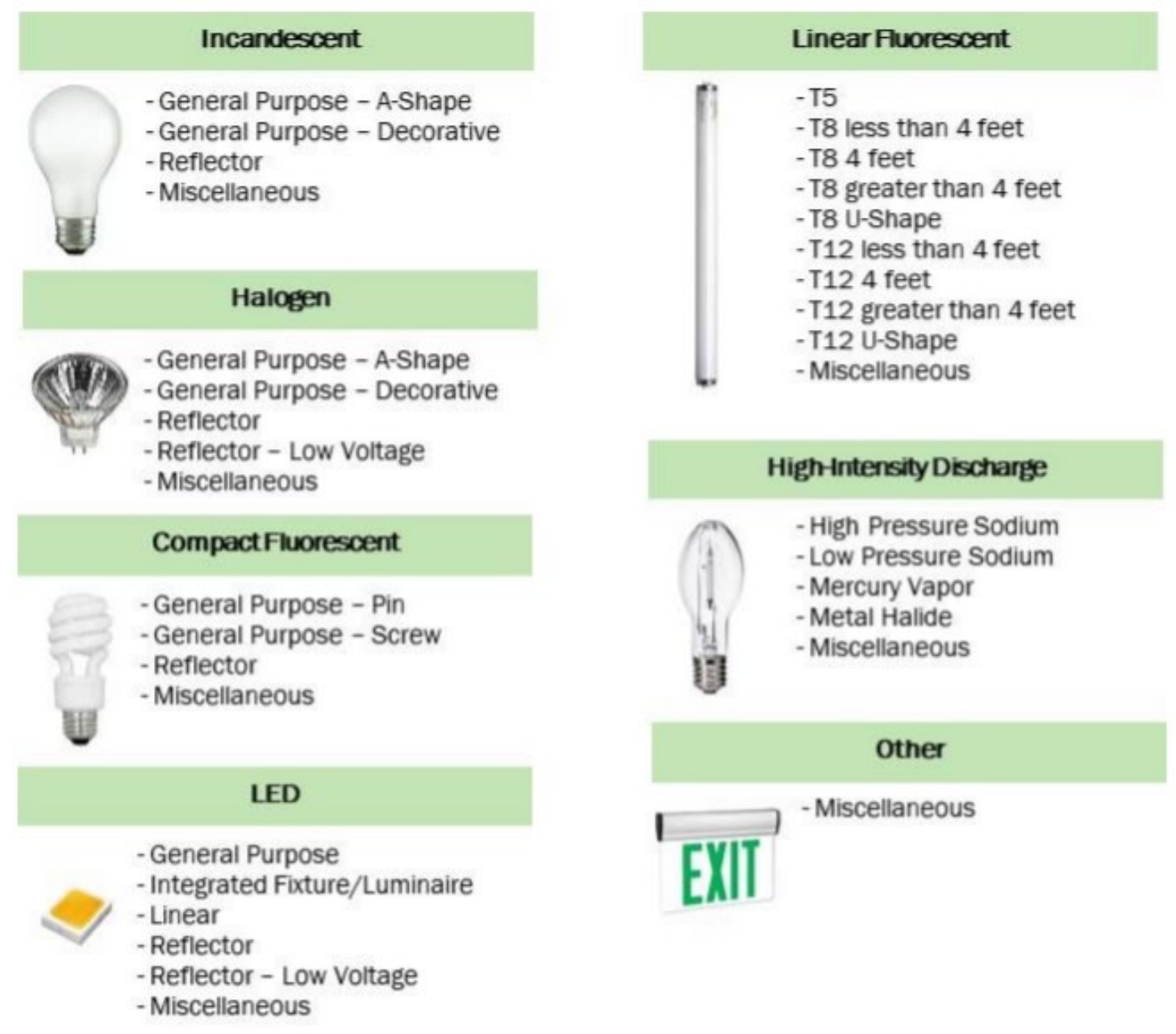

Figure 3.3: LMC Lighting Technology Classification [23] 
Current lighting energy usage $\left(\mathrm{CEU}_{\mathrm{L}}\right)$ for a given facility is estimated as

$\mathrm{CEU}_{\mathrm{L}} \quad=\mathrm{A}_{\mathrm{L}} \times \mathrm{B}_{\mathrm{L}} \times \mathrm{C}_{\mathrm{L}} \times \mathrm{D}_{\mathrm{L}} \times \mathrm{E}_{\mathrm{L}} \times \mathrm{F}_{\mathrm{L}}$

Where,

$\mathrm{A}_{\mathrm{L}}$

$=$ Average no. of Lamps per $1,000 \mathrm{ft}^{2}$ based on business type (First column in

Table 3.5)

$\mathrm{B}_{\mathrm{L}} \quad=$ Proportion of lights belonging to a technology (Entries of Table 3.4)

$\mathrm{C}_{\mathrm{L}} \quad=$ Average lighting wattage of a lighting technology (Entries of Table 3.7)

$\mathrm{D}_{\mathrm{L}} \quad=$ Area of the facility (in Sq.ft.) $/ 1000$

$\mathrm{E}_{\mathrm{L}} \quad=$ Operating Hours

$\mathrm{F}_{\mathrm{L}} \quad=\%$ of Area lit (Entries of Table 3.6)

\section{Example:}

$\mathrm{A}_{\mathrm{L}}$

$\mathrm{B}_{\mathrm{L}}$

$=24$ Lamps (First column in Table 3.5 for food service category)

$=$ Food service row of Table 3.4

$\mathrm{C}_{\mathrm{L}} \quad=$ Food service row of Table 3.7

$\mathrm{D}_{\mathrm{L}} \quad=5(5,000 \mathrm{Sq} . \mathrm{Ft} / 1,000 \mathrm{Sq} . \mathrm{Ft})$

$\mathrm{E}_{\mathrm{L}} \quad=3,060 \mathrm{hrs} /$ year

$\mathrm{F}_{\mathrm{L}} \quad=84.30 \%$ (Third column in for Table 3.6 food service category)

Table 3.3: Estimation of CEU for Lighting

\begin{tabular}{|c|c|c|c|}
\hline Lighting Technology & $\begin{array}{c}\mathbf{C}_{\mathbf{L}} \\
\text { (Avg. Watts per light) }\end{array}$ & $\begin{array}{c}\mathbf{A}_{\mathbf{L}} * \mathbf{B}_{\mathbf{L}} \\
\text { (No. of lights) }\end{array}$ & $\begin{array}{c}\mathbf{A}_{\mathbf{L}} * \mathbf{B}_{\mathbf{L}} * \mathbf{C}_{\mathbf{L}} * \mathbf{D}_{\mathbf{L}} * \mathbf{E}_{\mathbf{L}} * \mathbf{F}_{\mathbf{L}} / \mathbf{1 0 0 0} \\
(\mathbf{k} \mathbf{W h} / \mathbf{y} \mathbf{e a r})\end{array}$ \\
\hline Incandescent & 29.7 & 2.49 & 954 \\
\hline Halogen & 35.4 & 0.85 & 388 \\
\hline CFL & 20.8 & 2.01 & 539 \\
\hline Linear Fluorescent & 35.2 & 14.50 & 6,583 \\
\hline HID & 85.4 & 0.05 & 55 \\
\hline LED & 10.1 & 4.26 & 555 \\
\hline Other & 26.8 & 0.05 & 17 \\
\hline Total & - & $\mathbf{2 4}$ & $\mathbf{9 , 0 9 1}$ \\
\hline
\end{tabular}

Therefore, current energy usage for lighting $\left(\mathrm{CEU}_{\mathrm{L}}\right)$ for a food service facility with area 5,000 Sq.

Ft. and operating 3,060 hrs/year is estimated as shown in Table 3.3 and is $9,091 \mathrm{kWh} / \mathrm{yr}$. 
Table 3.4: Lighting Technology Distribution by Commercial Building Type in 2015 [23]

\begin{tabular}{|c|c|c|c|c|c|c|c|c|}
\hline \multicolumn{9}{|c|}{ Lighting Technology Distribution by Commercial Building Type in 2015} \\
\hline Sub Sector & Incandescent & Halogen & CFL & $\begin{array}{c}\text { Linear } \\
\text { Fluorescent }\end{array}$ & HID & LED & Other & Total \\
\hline Education & $0 \%$ & $0 \%$ & $4 \%$ & $89 \%$ & $1 \%$ & $7 \%$ & $0 \%$ & $100 \%$ \\
\hline Food sales & $0 \%$ & $1 \%$ & $2 \%$ & $78 \%$ & $5 \%$ & $13 \%$ & $0 \%$ & $100 \%$ \\
\hline Food service & $10 \%$ & $4 \%$ & $8 \%$ & $60 \%$ & $0 \%$ & $18 \%$ & $0 \%$ & $100 \%$ \\
\hline Health care & $2 \%$ & $2 \%$ & $11 \%$ & $73 \%$ & $0 \%$ & $12 \%$ & $0 \%$ & $100 \%$ \\
\hline Lodging & $4 \%$ & $1 \%$ & $43 \%$ & $30 \%$ & $0 \%$ & $22 \%$ & $0 \%$ & $100 \%$ \\
\hline Office & $1 \%$ & $1 \%$ & $4 \%$ & $87 \%$ & $1 \%$ & $8 \%$ & $0 \%$ & $100 \%$ \\
\hline Other & $1 \%$ & $1 \%$ & $16 \%$ & $71 \%$ & $1 \%$ & $11 \%$ & $0 \%$ & $100 \%$ \\
\hline $\begin{array}{l}\text { Public } \\
\text { assembly }\end{array}$ & $2 \%$ & $1 \%$ & $12 \%$ & $67 \%$ & $2 \%$ & $16 \%$ & $0 \%$ & $100 \%$ \\
\hline $\begin{array}{l}\text { Public order } \\
\text { and safety }\end{array}$ & $3 \%$ & $3 \%$ & $12 \%$ & $72 \%$ & $1 \%$ & $10 \%$ & $0 \%$ & $100 \%$ \\
\hline $\begin{array}{l}\text { Religious } \\
\text { worship }\end{array}$ & $3 \%$ & $1 \%$ & $13 \%$ & $70 \%$ & $1 \%$ & $12 \%$ & $1 \%$ & $100 \%$ \\
\hline $\begin{array}{l}\text { Retail (other } \\
\text { than mall) }\end{array}$ & $1 \%$ & $2 \%$ & $4 \%$ & $80 \%$ & $3 \%$ & $11 \%$ & $0 \%$ & $100 \%$ \\
\hline Service & $2 \%$ & $0 \%$ & $2 \%$ & $82 \%$ & $1 \%$ & $13 \%$ & $0 \%$ & $100 \%$ \\
\hline $\begin{array}{l}\text { Warehouse } \\
\text { and storage }\end{array}$ & $0 \%$ & $0 \%$ & $1 \%$ & $89 \%$ & $2 \%$ & $7 \%$ & $0 \%$ & $100 \%$ \\
\hline Average & $1 \%$ & $1 \%$ & $8 \%$ & $78 \%$ & $1 \%$ & $11 \%$ & $0 \%$ & $100 \%$ \\
\hline
\end{tabular}


Table 3.5: Lighting Electricity Use by Commercial Buildings in 2015 [23]

\begin{tabular}{|l|c|c|}
\hline \multicolumn{2}{|c|}{ Lighting Electricity Use by Commercial Buildings in 2015 } \\
\hline Sub Sector & Average Lamps per $\mathbf{1 , 0 0 0} \mathbf{f t}^{\mathbf{2}}$ & Installed Wattage (W/ft $\left.^{\mathbf{2}}\right)$ \\
\hline Education & 38 & 1.4 \\
\hline Food sales & 29 & 1.1 \\
\hline Food service & 24 & 0.7 \\
\hline Health Care & 18.5 & 0.6 \\
\hline Lodging & 26 & 0.6 \\
\hline Office & 19 & 0.6 \\
\hline Other & 24 & 0.8 \\
\hline Public assembly & 21 & 0.8 \\
\hline Public order and safety & 17 & 0.7 \\
\hline Religious worship & 30 & 1.0 \\
\hline Retail (other than mall) & 20 & 0.8 \\
\hline Service & 33 & 1.3 \\
\hline Warehouse and storage & 20 & 0.8 \\
\hline
\end{tabular}

Table 3.6: Total floorspace and lit floorspace by lighting type and Commercial Building Type [24]

\begin{tabular}{|l|c|c|c|}
\hline \multicolumn{4}{|c|}{$\%$ of Total floorspace lit by lighting type and principal building activity } \\
\hline Sub Sector & $\begin{array}{c}\text { Total floor-space } \\
\text { (million square feet) }\end{array}$ & $\begin{array}{c}\text { Total lit floor-space } \\
\text { (million square feet) }\end{array}$ & \% Area Lit \\
\hline Education & 12,239 & 11,005 & $89.9 \%$ \\
\hline Food sales & 1,252 & 1,162 & $92.8 \%$ \\
\hline Food service & 1,819 & 1,533 & $84.3 \%$ \\
\hline Health care & 4,155 & 3,800 & $91.5 \%$ \\
\hline Lodging & 5,826 & 4,669 & $80.1 \%$ \\
\hline Mercantile & 11,330 & 9,875 & $87.2 \%$ \\
\hline Retail (other than mall) & 5,439 & 4,876 & $89.6 \%$ \\
\hline Office & 15,952 & 13,696 & $85.9 \%$ \\
\hline Public assembly & 5,559 & 4,622 & $83.1 \%$ \\
\hline Public order and safety & 1,440 & 1,193 & $82.8 \%$ \\
\hline Religious worship & 4,557 & 3,099 & $68.0 \%$ \\
\hline Service & 4,630 & 3,563 & $77.0 \%$ \\
\hline Warehouse and storage & 13,077 & 8,621 & $65.9 \%$ \\
\hline Other & 2,002 & 1,585 & $79.2 \%$ \\
\hline Vacant & 3,256 & 305 & $9.4 \%$ \\
\hline
\end{tabular}


Table 3.7: Average Lighting Wattage by Commercial Building Type in 2015 [23]

\begin{tabular}{|c|c|c|c|c|c|c|c|c|}
\hline \multicolumn{9}{|c|}{ Average Lighting Wattage by Commercial Building Type in 2015} \\
\hline Sub Sector & Incandescent & Halogen & CFL & $\begin{array}{c}\text { Linear } \\
\text { Fluorescent }\end{array}$ & HID & LED & Other & Average \\
\hline Education & 118 & 154 & 29 & 34 & 410 & 25 & 6 & 36 \\
\hline Food sales & 82 & 57 & 27 & 35 & 141 & 21 & 8 & 38 \\
\hline Food service & 30 & 35 & 21 & 35 & 85 & 10 & 27 & 29 \\
\hline Health Care & 77 & 71 & 21 & 31 & 177 & 15 & 27 & 30 \\
\hline Lodging & 62 & 35 & 21 & 32 & 144 & 10 & 11 & 24 \\
\hline Office & 63 & 52 & 25 & 33 & 369 & 22 & 10 & 34 \\
\hline Other & 104 & 80 & 30 & 33 & 397 & 12 & 10 & 33 \\
\hline Public assembly & 61 & 58 & 30 & 35 & 299 & 21 & 27 & 37 \\
\hline Public order and safety & 214 & 51 & 30 & 36 & 175 & 15 & 6 & 40 \\
\hline Religious worship & 92 & 96 & 26 & 34 & 333 & 12 & 6 & 34 \\
\hline Retail (other than mall) & 75 & 63 & 26 & 36 & 330 & 16 & 42 & 41 \\
\hline Service & 64 & 59 & 24 & 36 & 393 & 14 & 5 & 39 \\
\hline Warehouse and storage & 48 & 54 & 29 & 32 & 457 & 40 & 15 & 42 \\
\hline Average & 67 & 60 & 24 & 34 & 361 & 19 & 17 & 36 \\
\hline
\end{tabular}


Energy costs are estimated based on the 2017 Utility bundled retail sales for commercial facilities from the Energy Information Agency. Values of dollar per kWh is estimated by averaging the dollar per kWh of various utilities for commercial facilities. For detailed costs by utility provider please refer to Appendix A-2.

Current lighting energy cost $\left(\mathrm{CEC}_{\mathrm{L}}\right)$ can be estimated as

$\mathrm{CEC}_{\mathrm{L}} \quad=\mathrm{CEU}_{\mathrm{L}} \times$ Cost per $\mathrm{kWh}$

$=9,091 \mathrm{kWh} / \mathrm{yr} \times \$ 0.1124 / \mathrm{kWh}$

$=\$ 1,022 / \mathrm{yr}$

Lighting is one of the low hanging fruits across businesses for energy savings, as the new technologies like Light Emitting Diodes (LED's) consume a significantly less energy for same output in comparison to their predecessors like fluorescent, metal halides etc. Lighting retrofits provide good return and payback on investment. Despite of good return on investment, LED technology penetration in the U.S. market is still at $8 \%$ of overall lighting inventory in the U.S.[23]. LED lamps are six to seven times more energy efficient than traditional incandescent lamps and have lifetime 25 times longer than traditional lights, as LEDs lights does not contain mercury and are considered more environmentally friendly than traditional bulbs [25].

It is recommended that the facility replace any old lighting technologies like incandescent, metal halides, high pressure sodium lamps etc. with the advanced lighting technologies like LEDs.

Proposed lighting energy usage $\left(\mathrm{PEU}_{\mathrm{L}}\right)$ for a given facility is estimated as

$\mathrm{PEU}_{\mathrm{L}} \quad=\mathrm{A}_{\mathrm{L}} \times \mathrm{B}_{\mathrm{L}} \times \mathrm{C}_{\mathrm{L}} \times \mathrm{D}_{\mathrm{L}} \times \mathrm{E}_{\mathrm{L}} \times \mathrm{F}_{\mathrm{L}}$

Where,

$\mathrm{A}_{\mathrm{L}} \quad=$ Average Lamps per $1,000 \mathrm{ft}^{2}$ based on business type (First column in 
Table 3.5)

$\mathrm{B}_{\mathrm{L}} \quad=100 \%$, as it is recommended to change all lights to LEDs.

$\mathrm{C}_{\mathrm{L}} \quad=$ Average lighting wattage of lighting technology (Entries of Table 3.7)

$\mathrm{D}_{\mathrm{L}} \quad=$ Area of the facility (in Sq.ft.) $/ 1000$

$\mathrm{E}_{\mathrm{L}} \quad=$ Operating Hours

$\mathrm{F}_{\mathrm{L}} \quad=\%$ of Area lit (Entries of Table 3.6)

\section{Example:}

$\mathrm{A}_{\mathrm{L}}$

$=24$ Lamps (First column in Table 3.5 for food service category)

$\mathrm{B}_{\mathrm{L}} \quad=100 \%$

$\mathrm{C}_{\mathrm{L}} \quad=10$ watts (Food service row of Table 3.7)

$\mathrm{D}_{\mathrm{L}} \quad=5(5,000 \mathrm{Sq} . \mathrm{Ft} / 1,000 \mathrm{Sq} . \mathrm{Ft})$

$\mathrm{E}_{\mathrm{L}} \quad=3,060 \mathrm{hrs} /$ year

$\mathrm{F}_{\mathrm{L}} \quad=84.30 \%$ (Third column in for Table 3.6 food service category)

$\mathrm{PEU}_{\mathrm{L}} \quad=24$ lamps $\times 100 \%$ x 10 watts/lamp $\times 5 \times 3,060 \mathrm{hrs} /$ year $\times 84.30 \% \mathrm{x}$ $1 \mathrm{~kW} / 1000 \mathrm{~W}$

$=3,126 \mathrm{kWh} / \mathrm{yr}$

Energy cost savings possible by replacing the current lighting systems, with LED's can be estimated as follows.

Proposed lighting energy cost $\left(\mathrm{PEC}_{\mathrm{L}}\right)$ can be estimated as

$\mathrm{PEC}_{\mathrm{L}} \quad=\mathrm{PEU}_{\mathrm{L}} \times$ Cost per $\mathrm{kWh}$

$=3,126 \mathrm{kWh} / \mathrm{yr} \times \$ 0.1124 / \mathrm{kWh}$

$=\$ 351 / \mathrm{yr}$

Total annual lighting energy cost Savings $\left(\mathrm{TACS}_{\mathrm{L}}\right)$ can be estimated as

$\mathrm{TACS}_{\mathrm{L}} \quad=\mathrm{CEC}_{\mathrm{L}}-\mathrm{PEC}_{\mathrm{L}}$

$=\$ 1,022 / \mathrm{yr}-\$ 351 / \mathrm{yr}$

$=\$ 671 / \mathrm{yr}$

Therefore, Total annual lighting energy cost Savings $\left(\mathrm{TACS}_{\mathrm{L}}\right)$ for a food service facility with area 5,000 Sq. Ft. and operating 3,060 hrs/year is estimated as $\$ 671 / \mathrm{yr}$. 


\subsection{HVAC}

Heating Ventilating and Air Conditioning (HVAC) system is responsible for maintaining the indoor temperature and ventilation conditions as desired by the occupants. A good HVAC system provides human comfort by regulating temperature and moisture. Carbon dioxide exhaled by occupants, and any heat or odor produced by machines etc., is removed by the HVAC system by re-circulating the inside and outside air to maintain desirable conditions for occupants.

HVAC systems contributed to $40 \%$ of the total energy consumption in the commercial sector [22]. 2012 Commercial Building Energy Consumption Survey (CBECS) dataset is considered for analysis as it provides good estimates to understand the energy profiles of commercial facilities in the US. CBECS also provides a very detailed energy use estimates with different combinations of sub sectors, energy systems and climate region.

For the purposes of this study it is assumed that the source of energy for cooling and ventilation is electricity and for heating it is natural gas. As space cooling and heating are largely a function of temperature, energy consumption estimates are calculated based on the location of the given facility instead of the commercial sub sector type to which the facility belongs.

The zip code for the facility considered in the example is 26505 which fall under Cold Climate region. For detailed list of counties for the state of WV and their climate regions, please see Appendix A-4.

Current HAVC energy usage (CEUHVAC) for a given facility is estimated as

$\mathrm{CEU}_{\mathrm{HVAC}}=\mathrm{CEU}_{\mathrm{C}}+\mathrm{CEU}_{\mathrm{H}}+\mathrm{CEU}_{\mathrm{V}}$

Where, $\mathrm{CEU}_{\mathrm{C}} \quad=$ Current Energy Usage for Cooling 


$\begin{array}{ll}\mathrm{CEU}_{\mathrm{H}} & =\text { Current Energy Usage for Heating } \\ \mathrm{CEU} & =\text { Current Energy Usage for Ventilation } \\ \mathrm{CEU}_{\mathrm{C}} & =\mathrm{A}_{\mathrm{C}} \times \mathrm{B}_{\mathrm{C}} \\ \text { Where, } & \\ \mathrm{A}_{\mathrm{C}} & =\text { Cooling energy intensity per Sq. } \mathrm{ft} \text { based on climate region (First column in } \\ \mathrm{B}_{\mathrm{C}} & \quad \text { Table } 3.8)\end{array}$

\section{Example:}

$\mathrm{A}_{\mathrm{C}}$

$=1.4 \mathrm{kWh} / \mathrm{sq}$. Ft (First column in Table 3.8 for cold climate region)

$\mathrm{B}_{\mathrm{C}}$

$=5,000 \mathrm{Sq} . \mathrm{Ft}$

$\mathrm{CEU}_{\mathrm{C}} \quad=1.4 \mathrm{kWh} / \mathrm{sq} . \mathrm{Ft} /$ year $\times 5,000 \mathrm{Sq} . \mathrm{Ft}$

$=7,000 \mathrm{kWh} / \mathrm{yr}$.

$\mathrm{CEU}_{\mathrm{V}} \quad=\mathrm{A}_{\mathrm{V}} \times \mathrm{B}_{\mathrm{V}}$

Where,

Av

$=$ Ventilation energy intensity per Sq. $\mathrm{ft}$ based on climate region (Second column Table 3.8)

$\mathrm{B}_{\mathrm{V}} \quad=$ Area of the facility (in Sq. Ft.)

\section{Example:}

$\mathrm{Av}_{\mathrm{v}}$

$\mathrm{B}_{\mathrm{V}}$

$=2.4 \mathrm{kWh} / \mathrm{sq}$. Ft (Second column in Table 3.8 for cold climate region)

$=5,000$ Sq. $\mathrm{Ft}$

CEUV $\quad=2.4 \mathrm{kWh} / \mathrm{sq} . \mathrm{Ft} / \mathrm{year} \times 5,000 \mathrm{Sq} . \mathrm{Ft}$

$=12,000 \mathrm{kWh} / \mathrm{yr}$.

$\mathrm{CEU}_{\mathrm{H}} \quad=\mathrm{A}_{\mathrm{H}} \times \mathrm{B}_{\mathrm{H}} \times \mathrm{C}_{\mathrm{H}}$

Where,

$\mathrm{A}_{\mathrm{H}}$

$=$ Heating energy intensity per Sq. $\mathrm{ft}$ based on climate region (third column in Table 3.8)

$\mathrm{B}_{\mathrm{H}} \quad=$ Area of the facility (in Sq.ft.)

$\mathrm{C}_{\mathrm{H}} \quad=1 \mathrm{MMBtu} / 10^{3} \mathrm{Btu}$ (thousand Btu to MMBtu conversion)

\section{Example:}




$\begin{array}{ll}\mathrm{B}_{\mathrm{H}} & =5,000 \mathrm{Sq} . \mathrm{Ft} \\ \mathrm{C}_{\mathrm{H}} & =1 \mathrm{MMBtu} / 10^{3} \mathrm{Btu} \\ & \\ \mathrm{CEU}_{\mathrm{H}} & =35.8 \mathrm{MMBtu} / \mathrm{sq} . \text { Ft/year x 5,000 Sq. Ft x } 1 \mathrm{MMBtu} / 10^{3} \mathrm{Btu} \\ & =179 \mathrm{MMBtu} / \mathrm{yr} .\end{array}$

In recent years, HVAC technology has improved in terms energy efficiency and with the advent of sensor and computing power, control strategies for HVAC have also become more sophisticated. HVAC energy savings study by Pacific Northwest Laboratory estimates that more than $60 \%$ of the commercial building floor space is served by packaged air-conditioners and heat pumps[26]. This study looks at the energy savings and economics of advanced control strategies for packaged air-conditioning units with gas heat. It is estimated that by installing advanced technologies and control strategies like integrated differential dry-bulb economizer, multi-speed supply fan, Demand Control Ventilation (DCV) etc., a facility can save on their HVAC energy usage anywhere between $24 \%$ to $35 \%$ [26]. Depending on the age and technology of the existing equipment and technology of the new equipment being installed, there is a possibility to achieve more savings.

Heating, Ventilation, Air and Conditioning (HVAC) is a combination of multiple systems. Building envelope play a major role in the energy consumption of the HVAC systems. Unlike more simple systems like lighting where a specific recommendation can be made, systems like HVAC and their interaction with factors like building envelope make it hard to recommend a pinpointed strategy without fully knowing the system.

To simplify, based on the HVAC savings study previously mentioned, it is assumed that energy efficiency recommendations can save around $24 \%$ the current HVAC usage. 
Table 3.8: Energy Intensity by the End Use by Climate Region [27]

\begin{tabular}{|l|c|c|c|}
\hline \multirow{2}{*}{$\begin{array}{l}\text { Climate } \\
\text { region }\end{array}$} & \multicolumn{2}{|c|}{$\begin{array}{c}\text { Electricity energy intensity } \\
\text { (kWh/square foot in buildings } \\
\text { using electricity for the end use) }\end{array}$} & $\begin{array}{r}\text { Natural gas energy intensity } \\
\text { (thousand Btu/square foot in } \\
\text { buildings using natural gas for the } \\
\text { end use) }\end{array}$ \\
\cline { 2 - 4 } & Cooling & Ventilation & Space heating \\
\hline $\begin{array}{l}\text { Very } \\
\text { cold/Cold }\end{array}$ & 1.4 & 2.4 & 35.8 \\
\hline Mixed-humid & 2.5 & 2.4 & 22.8 \\
\hline $\begin{array}{l}\text { Mixed- } \\
\text { dry/Hot-dry }\end{array}$ & 2.1 & 2.0 & 14.2 \\
\hline Hot-humid & 5.4 & 2.6 & 14.6 \\
\hline Marine & 0.9 & 2.8 & 23.4 \\
\hline
\end{tabular}

Energy cost savings possible by retrofitting or replacing the current HVAC system, with integrated differential dry-bulb economizer, multi-speed supply fan, Demand Control Ventilation (DCV) etc. can be estimated as shown below.

Natural Gas Energy costs are estimated based on the West Virginia Price of Natural Gas Sold to Commercial Consumers (Dollars per Thousand Cubic Feet) from the Energy Information Agency. Values of dollar per $\mathrm{kWh}$ is estimated by averaging the dollar per Thousand Cubic Feet for commercial facilities in the year 2017. For detailed NG costs for the state of WV please refer to Appendix A-3.

Current Cooling energy cost $\left(\mathrm{CEC}_{\mathrm{C}}\right)$ can be estimated as

$\mathrm{CEC}_{\mathrm{C}} \quad=\mathrm{CEU}_{\mathrm{C}} \mathrm{x}$ Cost per $\mathrm{kWh}$

$=7,000 \mathrm{kWh} / \mathrm{yr} \times \$ 0.1124 / \mathrm{kWh}$

$=\$ 787 / \mathrm{yr}$

Current Ventilation energy cost $\left(\mathrm{CEC}_{\mathrm{V}}\right)$ can be estimated as

$$
\begin{aligned}
\mathrm{CECV}_{\mathrm{V}} & =\mathrm{CEU}_{\mathrm{V}} \times \text { Cost per } \mathrm{kWh} \\
& =12,000 \mathrm{kWh} / \mathrm{yr} \times \$ 0.1124 / \mathrm{kWh} \\
& =\$ 1,349 / \mathrm{yr}
\end{aligned}
$$


Current Heating energy cost $\left(\mathrm{CEC}_{\mathrm{H}}\right)$ can be estimated as

$\mathrm{CEC}_{\mathrm{H}}=\mathrm{CEU}_{\mathrm{H}} \mathrm{x}$ Cost per MMBtu

$=179 \mathrm{MMBtu} / \mathrm{yr}$ x $\$ 8.21 / \mathrm{MCF}$ x $1.025 \mathrm{MMBtu} / \mathrm{MCF}$

$=\$ 1,470 / \mathrm{yr}$

Proposed Cooling energy cost $\left(\mathrm{PEC}_{\mathrm{C}}\right)$ can be estimated as

$\mathrm{PEC}_{\mathrm{C}}=\mathrm{PEU}_{\mathrm{C}} \times$ Cost per $\mathrm{kWh} \times(100 \%-\%$ of HVAC savings $)$

$=7,000 \mathrm{kWh} / \mathrm{yr} \times \$ 0.1124 / \mathrm{kWh} \times(100 \%-24 \%)$

$=\$ 598 / \mathrm{yr}$

Proposed Ventilation energy cost $\left(\mathrm{PEC}_{\mathrm{V}}\right)$ can be estimated as

$\mathrm{PEC}_{\mathrm{V}}=\mathrm{CEU}_{\mathrm{V}} \times \mathrm{Cost}$ per $\mathrm{kWh} \times(100 \%-\%$ of HVAC savings $)$

$=12,000 \mathrm{kWh} / \mathrm{yr} \times \$ 0.1124 / \mathrm{kWh} \times(100 \%-24 \%)$

$=\$ 1,025 / \mathrm{yr}$

Proposed Heating energy cost $\left(\mathrm{PEC}_{\mathrm{H}}\right)$ can be estimated as

$\mathrm{PEC}_{\mathrm{H}}=\mathrm{CEU}_{\mathrm{H}} \mathrm{x}$ Cost per MMBtu $\mathrm{x}(100 \%-\%$ of HVAC savings $)$

$=179 \mathrm{MMBtu} / \mathrm{yr}$ x $\$ 8.21 / \mathrm{MCF}$ x $1.025 \mathrm{MMBtu} / \mathrm{MCF} \times(100 \%-24 \%)$

$=\$ 1,145 / \mathrm{yr}$

Total annual current HVAC energy costs (TACEC $\mathrm{HVAC}_{\mathrm{H}}$ ) can be estimated as

$\mathrm{TACEC}_{\mathrm{HVAC}}=\mathrm{CEC}_{\mathrm{C}}+\mathrm{CEC}_{\mathrm{V}}+\mathrm{CEC}_{\mathrm{H}}$

$=\$ 787 / \mathrm{yr}+\$ 1,349 / \mathrm{yr}+\$ 1,470 / \mathrm{yr}$

$=\$ 3,606 / \mathrm{yr}$

Total annual proposed HVAC energy costs (TAPEC $\mathrm{HVAC}_{\mathrm{H}}$ ) can be estimated as

$\mathrm{TAPEC}_{\mathrm{HVAC}}=\mathrm{PEC}_{\mathrm{C}}+\mathrm{PEC}_{\mathrm{V}}+\mathrm{PEC}_{\mathrm{H}}$

$=\$ 598 / \mathrm{yr}+\$ 1,025 / \mathrm{yr}+\$ 1,145 / \mathrm{yr}$

$=\$ 2,768 / \mathrm{yr}$

Total annual HVAC energy cost savings (TACS HVAC $_{\text {) }}$ can be estimated as

TACS $_{\text {HVAC }}=$ TACEC $_{\text {HVAC }}-\mathrm{TAPEC}_{\mathrm{HVAC}}$

$=\$ 3,606 / \mathrm{yr}-\$ 2,768 / \mathrm{yr}$

$=\$ 838 / \mathrm{yr}$ 


\subsection{Water Heater}

Hot water is one of the most common types of energy consuming equipment which is present across various businesses. One common use of hot water is for comfort. Depending on the type of operation a commercial facility, hot water can be used for various purposes like dishwashers, sanitizing floors, laundry, pools etc.

2012 Commercial Building Energy Consumption Survey (CBECS) dataset is considered for analysis as it provides good estimates to understand the energy profiles of commercial facilities in the US. CBECS also provides a very detailed energy use estimates with different combinations of sub sectors, energy systems and climate region.

For the purposes of this study it is assumed that the source of energy for hot water is natural gas. As hot water usage is largely a function of type of the operation facility is doing, energy consumption estimates are calculated based on the commercial sub sector type of the given facility instead of the climate zone.

Current hot water energy usage $\left(\mathrm{CEU}_{\mathrm{HW}}\right)$ for a given facility is estimated as

$\mathrm{CEU}_{\mathrm{HW}} \quad=\mathrm{A}_{\mathrm{HW}} \times \mathrm{B}_{\mathrm{HW}} \times \mathrm{C}_{\mathrm{HW}}$

Where,

$\mathrm{A}_{\mathrm{HW}} \quad=$ Heating energy intensity per Sq. $\mathrm{ft}$ based on business (third column in Table 3.9)

$\mathrm{B}_{\mathrm{HW}} \quad=$ Area of the facility (in Sq.ft.)

$\mathrm{C}_{\mathrm{HW}}=1 \mathrm{MMBtu} / 10^{3} \mathrm{Btu}$ (thousand Btu to MMBtu conversion)

\section{Example:}

$\begin{array}{ll}\mathrm{A}_{\mathrm{HW}} & =39.2 \mathrm{Btu} / \mathrm{sq} . \mathrm{Ft}(\text { Food sales row column in Table 3.9) } \\ \mathrm{B}_{\mathrm{HW}} & =5,000 \mathrm{Sq} . \mathrm{Ft} \\ \mathrm{C}_{\mathrm{HW}} & =1 \mathrm{MMBtu} / 10^{3} \mathrm{Btu}\end{array}$


$\mathrm{CEU}_{\mathrm{HW}}=39.2 \mathrm{MMBtu} / \mathrm{sq}$. Ft/year x 5,000 Sq. Ft x $1 \mathrm{MMBtu} / 10^{3} \mathrm{Btu}$

$=196 \mathrm{MMBtu} / \mathrm{yr}$.

Current hot water energy cost $\left(\mathrm{CEC}_{\mathrm{HW}}\right)$ can be estimated as

$\mathrm{CEC}_{\mathrm{HW}} \quad=\mathrm{CEU}_{\mathrm{H}} \mathrm{x}$ Cost per MMBtu

$=196 \mathrm{MMBtu} / \mathrm{yr}$ x x $\$ 8.21 / \mathrm{MCF}$ x $1.025 \mathrm{MMBtu} / \mathrm{MCF}$

$=\$ 1,649 / \mathrm{yr}$

Traditionally water is heated at a central source like a boiler and is supplied to the point of use, this process has some disadvantages to it. In general, thermal systems are not very efficient, above that when a working fluid is stored or made to travel to reach its destination, there will be standby and transportation losses associated with it. Instantaneous water heaters provide hot water only as it is needed. They heat the water directly without the use of a storage tank, thus avoiding the standby losses associated with the storage water heaters. When a hot water tap is turned on, cold water travels through a pipe into the instantaneous unit. Either a gas burner or an electric element heats the water and as a result, demand water heaters deliver a constant supply of hot water.

Energy and cost comparison study for a 50-gallon capacity gas water heating by Energy Star has shown that the gas heated tankless water heater consumes around 30\% less energy when compared a standard gas water heater [28]. So, for the purposes of this study, it is estimated that the facility can achieve a $30 \%$ reduction in hot water energy usage if they replace the traditional gas based hot water heater with a gas heated tankless water heater.

Proposed hot water energy usage (PEUHW) can be estimated as

PEU $_{\text {HW }}=$ CEUHW $_{\text {HW }}(100 \%-\%$ of Hot Water Energy Savings $)$

$=196 \mathrm{MMBtu} / \mathrm{yr} \times(100 \%-30 \%)$

$=137 \mathrm{MMBtu} / \mathrm{yr}$

Proposed hot water energy cost $\left(\mathrm{PEC}_{\mathrm{HW}}\right)$ can be estimated as 
$\mathrm{PEC}_{\mathrm{HW}} \quad=\mathrm{PEU}_{\mathrm{HW}} \mathrm{x}$ Cost per MMBtu

$=137 \mathrm{MMBtu} / \mathrm{yr}$ x $\$ 8.21 / \mathrm{MCF}$ x $1.025 \mathrm{MMBtu} / \mathrm{MCF}$

$=\$ 1,153 / \mathrm{yr}$

Total annual hot water energy cost savings ( $\left.\mathrm{TACS}_{\mathrm{HW}}\right)$ can be estimated as

$\mathrm{TACS}_{\mathrm{HW}}=\mathrm{CEC}_{\mathrm{H}}-\mathrm{PEC}_{\mathrm{HW}}$

$=\$ 1,649 / \mathrm{yr}-\$ 1,153 / \mathrm{yr}$

$=\$ 496 / \mathrm{yr}$

\subsection{Facilities' Total Energy Usage}

After estimating the energy and cost savings for different energy systems and possible energy conservation measures, facility's total energy usage was estimated. As the energy systems considered here are not comprehensive, summing up the energy usage for the lighting, HVAC and hot water heaters may not give a good idea about the total energy consumption of the whole facility.

In order to estimate the annual energy usage for a given facility, Energy Utilization Index from the 2012 Commercial Building Energy Consumption Survey (CBECS) dataset was considered for analysis. This dataset provides good estimates to understand the energy profile of commercial facilities in the US. CBECS also provides a very detailed energy use estimates with different combinations of sub sectors, energy systems and climate region.

It is assumed that the facility uses only two types of fuels i.e. electricity and natural gas. 
Table 3.9: Natural gas consumption and conditional energy intensities (Btu) by end use [29]

\begin{tabular}{|l|c|}
\hline \multicolumn{2}{|c|}{ Natural gas consumption and conditional energy intensities (Btu) by end use, 2012} \\
\hline \multicolumn{1}{|c|}{ Principal building activity } & Water heating \\
\hline Education & 7.0 \\
\hline Food sales & 4.4 \\
\hline Food service & 39.2 \\
\hline Health care & 23.7 \\
\hline Lodging & 34.3 \\
\hline Retail (other than mall) & 3.9 \\
\hline Office & 26.5 \\
\hline Public assembly & 10.6 \\
\hline Public order and safety & 2.5 \\
\hline Religious worship & 14.1 \\
\hline Service & 4.8 \\
\hline Warehouse and storage & 2.1 \\
\hline Other & 21.4 \\
\hline Vacant & $\mathrm{Q}$ \\
\hline
\end{tabular}

Table 3.10: Natural gas consumption intensities by Climate Region [27]

\begin{tabular}{|l|c|}
\hline Climate region & Natural gas consumption "per square foot (cubic feet)" \\
\hline Very cold/Cold & 43.7 \\
\hline Mixed-Humid & 33.1 \\
\hline Mixed-dry/Hot-dry & 33.1 \\
\hline Hot-humid & 31.4 \\
\hline Marine & 32.7 \\
\hline
\end{tabular}

Facilities total annual electrical energy usage is estimated based on commercial building type, whereas for natural gas energy usage is estimated based on climate region. As heating is the major contributor to facilities energy usage and is largely a function of the ambient temperature, natural gas consumption is calculated based on the climate region instead of business type.

Current electric energy usage $\left(\mathrm{CEU}_{\mathrm{E}}\right)$ for a given facility is estimated as 
$\mathrm{CEU}_{\mathrm{E}} \quad=\mathrm{A}_{\mathrm{E}} \times \mathrm{B}_{\mathrm{E}}$

Where,

$\mathrm{A}_{\mathrm{E}} \quad=$ Electric energy intensity per Sq. $\mathrm{ft}$ based on business type (values in Table 3.11)

$\mathrm{B}_{\mathrm{E}} \quad=$ Area of the facility (in Sq.ft.)

\section{Example:}

$\mathrm{A}_{\mathrm{E}} \quad=44.9 \mathrm{kWh} / \mathrm{sq}$. Ft (Food sales row column in Table 3.11)

$\mathrm{B}_{\mathrm{E}} \quad=5,000 \mathrm{Sq} . \mathrm{Ft}$

$\mathrm{CEU}_{\mathrm{E}} \quad=44.9 \mathrm{kWh} / \mathrm{sq} . \mathrm{Ft} /$ year $\times 5,000 \mathrm{Sq} . \mathrm{Ft}$

$=224,500 \mathrm{kWh} /$ year.

Current natural gas energy usage $\left(\mathrm{CEU}_{\mathrm{NG}}\right)$ for a given facility is estimated as

$\mathrm{CEU}_{\mathrm{NG}} \quad=\mathrm{A}_{\mathrm{NG}} \times \mathrm{B}_{\mathrm{NG}} \times \mathrm{C}_{\mathrm{NG}}$

Where,

$\mathrm{A}_{\mathrm{NG}} \quad=$ Heating energy intensity per Sq. $\mathrm{ft}$ based on climate region (values of Table 3.10)

$\mathrm{B}_{\mathrm{NG}} \quad=$ Area of the facility (in Sq.ft.)

$\mathrm{C}_{\mathrm{NG}} \quad=0.001025 \mathrm{MMBtu}$ (cubic $\mathrm{ft}$ to MMBtu conversion)

\section{Example:}

A $\quad=44.9$ thousand Btu/sq. Ft (Food sales row column in Table 3.11)

$\mathrm{B} \quad=5,000 \mathrm{Sq} . \mathrm{Ft}$

$\mathrm{CEU}_{\mathrm{NG}}=43.7 \mathrm{MMBtu} / \mathrm{sq} . \mathrm{Ft} /$ year $\mathrm{x} 5,000 \mathrm{Sq} . \mathrm{Ft} \times 1 \mathrm{ft}^{3} / 1025 \mathrm{Btu}$ $=224 \mathrm{MMBtu} /$ year.

A food service facility with 5,000 sq. ft area, operating 3,060 hours per year and located in a cold climate zone is estimated to consume $224,500 \mathrm{kWh}$ and 224 MMBtu annually. 
Table 3.11: Electricity Consumption Intensities by Commercial Building Type [30]

\begin{tabular}{|l|c|}
\hline Principal building activity & Electricity consumption (Per square foot) \\
\hline Education & 11.0 \\
\hline Food sales & 48.7 \\
\hline Food service & 44.9 \\
\hline Health care & 25.8 \\
\hline Inpatient & 31.0 \\
\hline Outpatient & 18.7 \\
\hline Lodging & 15.3 \\
\hline Mercantile & 18.3 \\
\hline Retail (other than mall) & 15.2 \\
\hline Enclosed and strip malls & 21.1 \\
\hline Office & 15.9 \\
\hline Public assembly & 14.5 \\
\hline Public order and safety & 14.9 \\
\hline Religious worship & 5.2 \\
\hline Service & 8.3 \\
\hline Warehouse and storage & 6.6 \\
\hline Other & 28.3 \\
\hline Vacant & 4.5 \\
\hline
\end{tabular}

It should be noted that the energy conservation measures recommended here are not exhaustive, an in-depth look at the facilities operations in-person through a lens of an energy audit would a give a more accurate idea for developing comprehensive and more specific energy conservation measures. The energy conservation measures recommended here are to provide an idea about the most common energy systems and most common possible energy conservation opportunities.

A summary of the possible energy conservation measures and current energy costs, proposed energy cost and annual cost savings calculated for the example facility are presented in Table 3.12. 
Table 3.12: Energy Cost Savings for a Commercial Facility

\begin{tabular}{|c|c|c|c|c|c|}
\hline S. No & $\begin{array}{l}\text { Energy } \\
\text { Systems }\end{array}$ & Possible Recommendation & $\begin{array}{c}\text { Current } \\
\text { Energy Costs } \\
(\$ / y r)\end{array}$ & $\begin{array}{c}\text { Proposed } \\
\text { Energy Costs } \\
(\$ / y \mathbf{y})\end{array}$ & $\begin{array}{c}\text { Savings } \\
(\$ / y r)\end{array}$ \\
\hline 1 & HVAC & $\begin{array}{l}\text { Retrofit HVAC units with } \\
\text { Economizer, Multi-Speed Supply } \\
\text { Fan, Demand-Controlled } \\
\text { Ventilation [DCV] etc. }\end{array}$ & $\$ 3,606$ & $\$ 2,768$ & $\$ 838$ \\
\hline 2 & Lighting & $\begin{array}{l}\text { Replace Linear Fluorescent, CFL, } \\
\text { MH etc. to LEDs }\end{array}$ & $\$ 1,022$ & $\$ 351$ & $\$ 671$ \\
\hline 3 & $\begin{array}{l}\text { Water } \\
\text { Heater }\end{array}$ & $\begin{array}{c}\text { Replace Standard Tank Based Gas } \\
\text { Water Heater with Tankless Gas } \\
\text { Water Heater }\end{array}$ & $\$ 1,649$ & $\$ 1,153$ & $\$ 496$ \\
\hline Total & - & - & 25,090 & 16,508 & $\$ 8,581$ \\
\hline
\end{tabular}

A computer program was developed to generate information shown in Table 3.12. The Graphical User Interface (GUI) of the program shown in Figure 3.4. The program output is shown in Figure 3.5 .

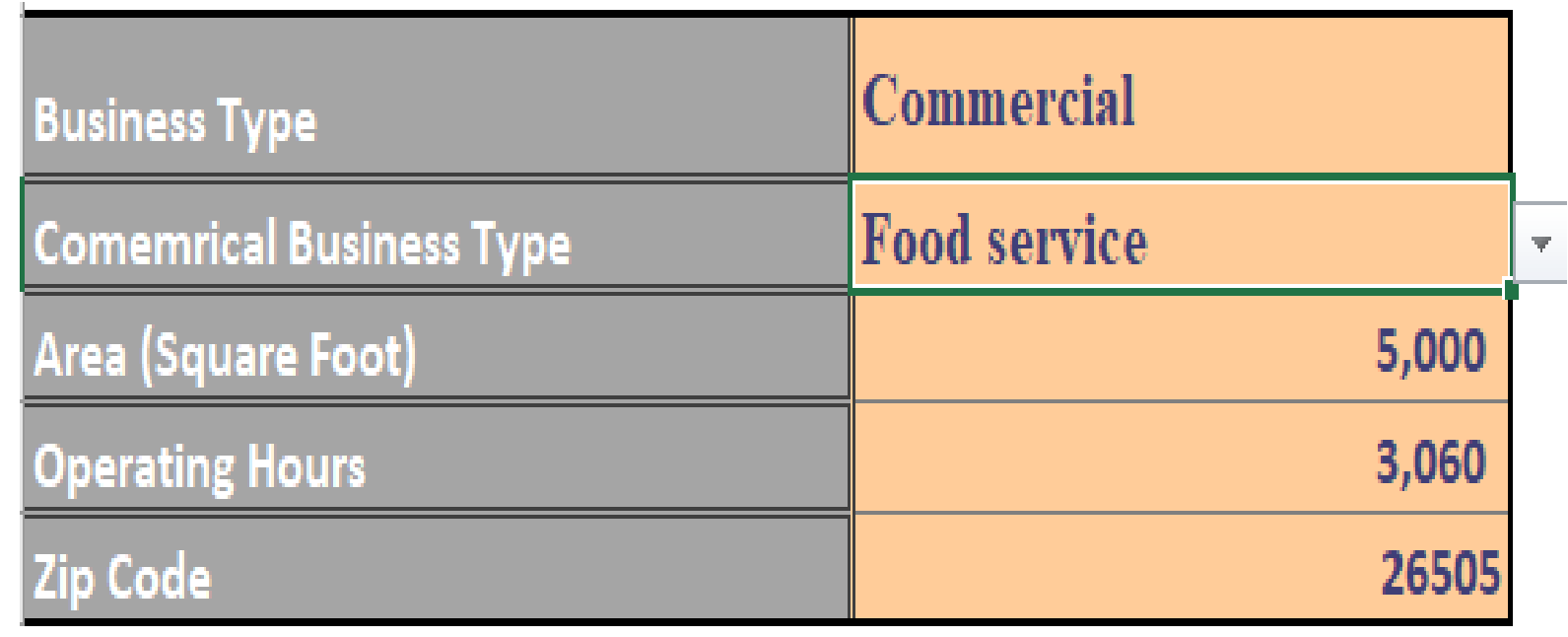

Figure 3.4: GUI for the commercial Virtual Energy Audit program 


\section{Dear Business Owner:}

Our team at WVU has performed a virtual energy audit for your business, Here are some key findings

- Based on energy per sq. $\mathrm{ft}$, it is estimated that your facility consumes $224500 \mathrm{kWh} / \mathrm{yr}$ and 224

MMBtu/yr.

- Your facility can save around $\$ 2034$ per year in energy costs by implementing the energy efficient technologies ( see table below for additional information)

\section{Potential Energy Saving Opportunites}

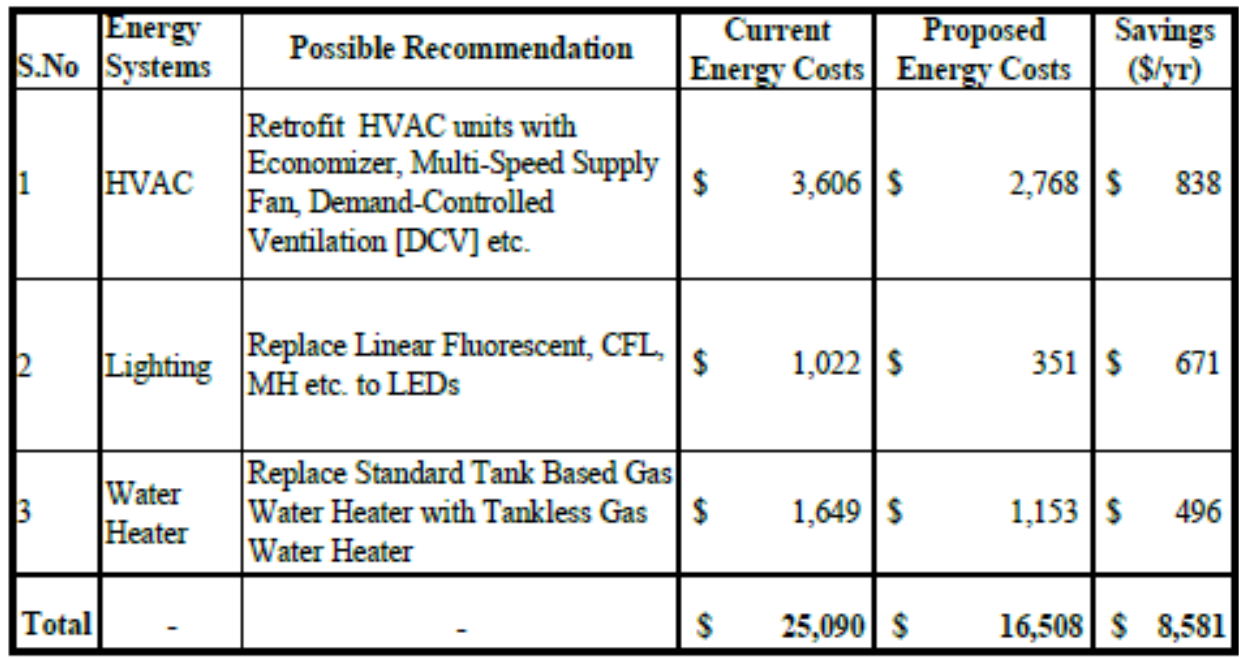

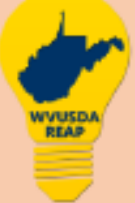

We can make your business energy efficient, Please visit us at https://industrialassessmentcenter.wvu.edu/

Figure 3.5: Output provided by the commercial Virtual Energy Audit program. 


\subsubsection{Commercial Virtual Energy Audit Tool Validation}

After the commercial virtual energy audit tool was built, results from the commercial virtual energy audit tool were compared to the actual values from an energy audit for validation. A total of twenty commercial facilities were considered for validation. Eighteen facilities had both electricity and natural gas as a source of energy and two facilities had just electricity as a source of energy. All the twenty facilities had energy efficiency recommendations for lighting systems and eighteen facilities had recommendation for HVAC systems. Only seven facilities had recommendations for hot water systems.

Data required for estimating savings using commercial virtual energy audit tool under for commercial facilities under consideration along with their associated estimated and actual annual energy consumption values are given in Appendix A-6. Estimated and actual energy cost savings values for all the facilities and their associated energy systems are given in Appendix A-7.

Estimated and actual annual $\mathrm{kWh}$ and natural gas comparison for various commercial facilities are shown in Figure 3.6 and Figure 3.7. In comparison to estimated electricity consumption values, estimated natural gas consumption values are having greater deviation from the estimated values, one reason for this could be, natural gas consumption is calculated based on the climate region rather than commercial activity of the facility. And the facilities considered here for validation are having special type of operations which fall into more than one commercial definitions. 


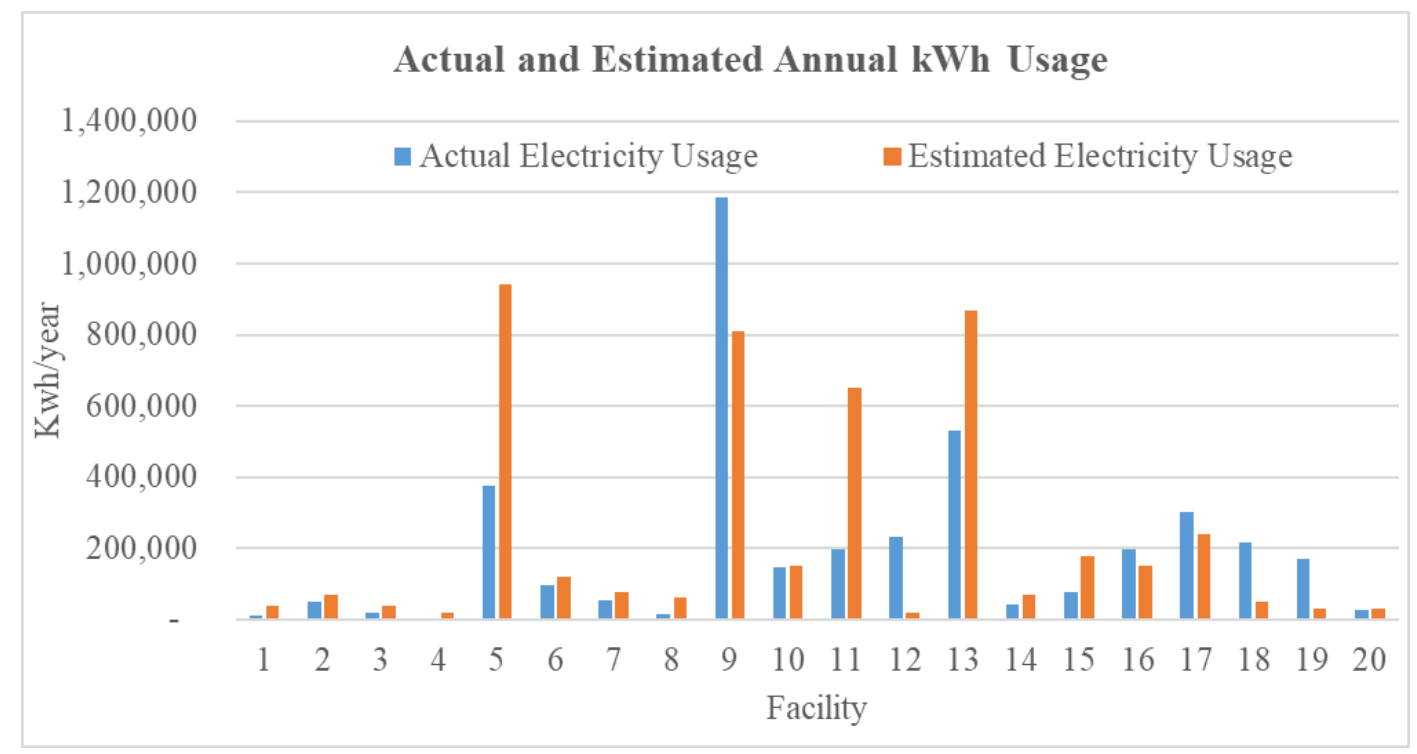

Figure 3.6: Actual and Estimated Annual kWh Usage

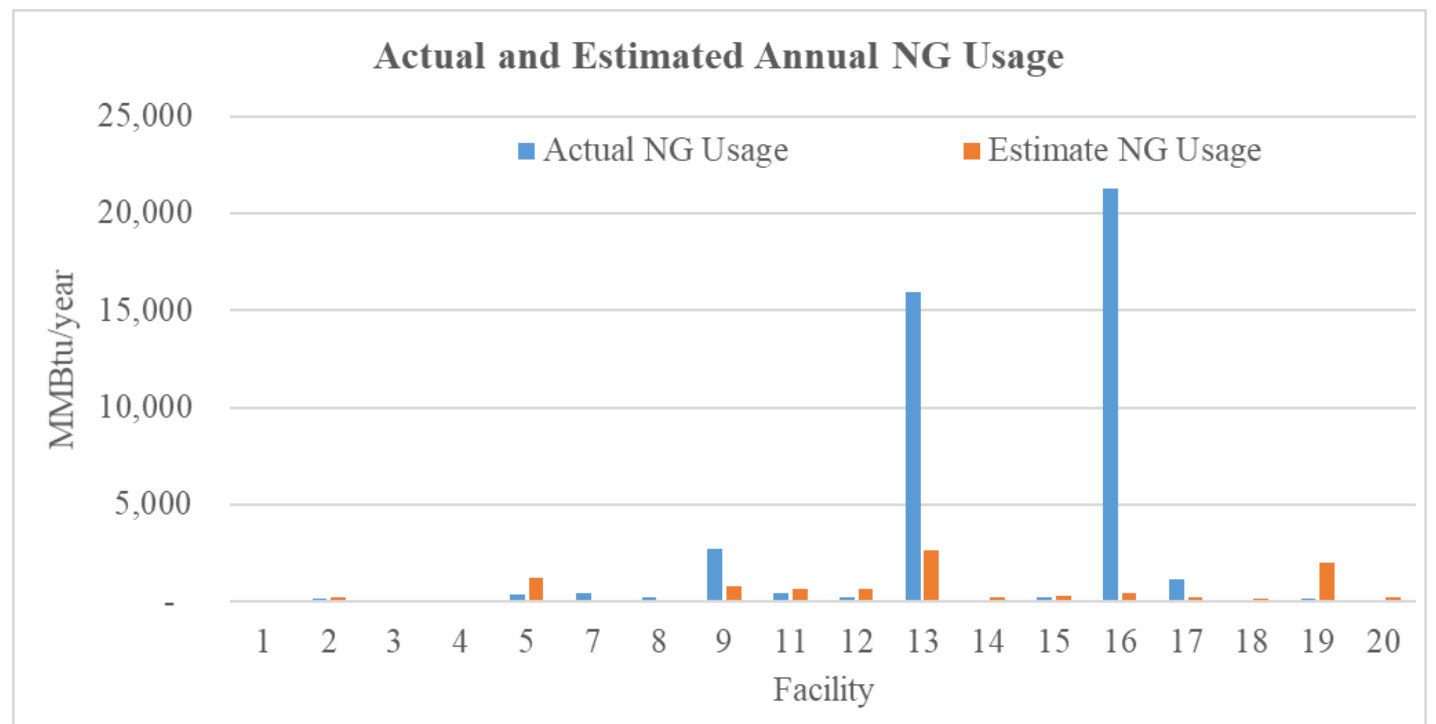

Figure 3.7:Actual and Estimated Annual Natural Gas Usage

Estimated and actual energy cost savings for lighting, HVAC and hot water heater are given in Figure 3.8, Figure 3.9 and Figure 3.10 respectively. 
The commercial virtual energy audit tool considers only inside lighting of the facility for estimating the cost savings for lighting systems. One of the reasons for discrepancies between the estimated and actual lighting cost savings shown in Figure 3.8 could be because of outside lighting. Few of the facilities considered here have large outdoor lighting. Generally outdoor light wattages are greater than the indoor light wattages and estimated lighting energy costs savings are a function of operating hours, this is could be one reason for having large discrepancies in actual lighting and estimated lighting energy cost savings. As mentioned earlier few of facilities have special type of operations and the HVAC and hot water energy cost savings are function of area of the facility and the climate zone and does not consider the operating hours of the facility. These can be the reasons for discrepancies in the estimated and actual cost savings values.

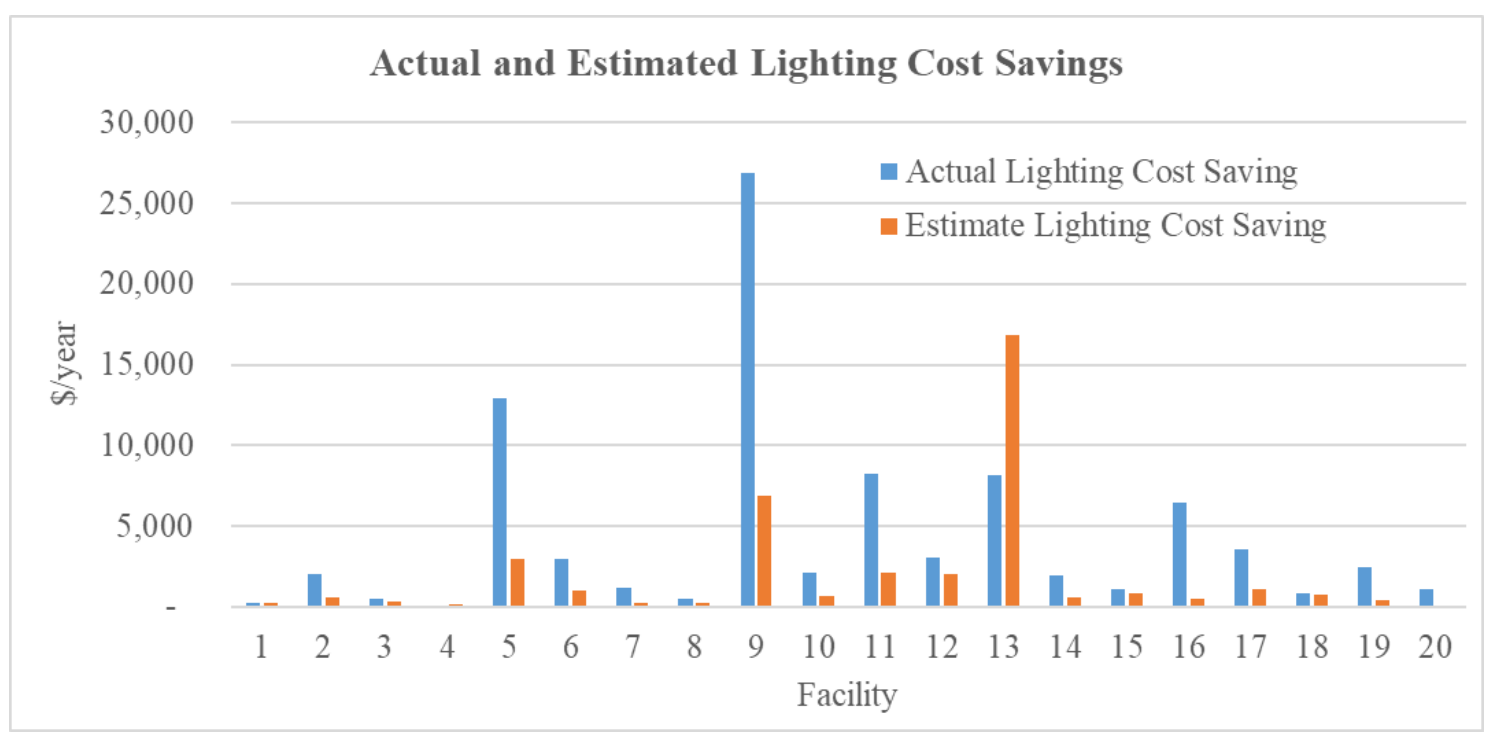

Figure 3.8:Actual and Estimated Lighting Cost Savings 


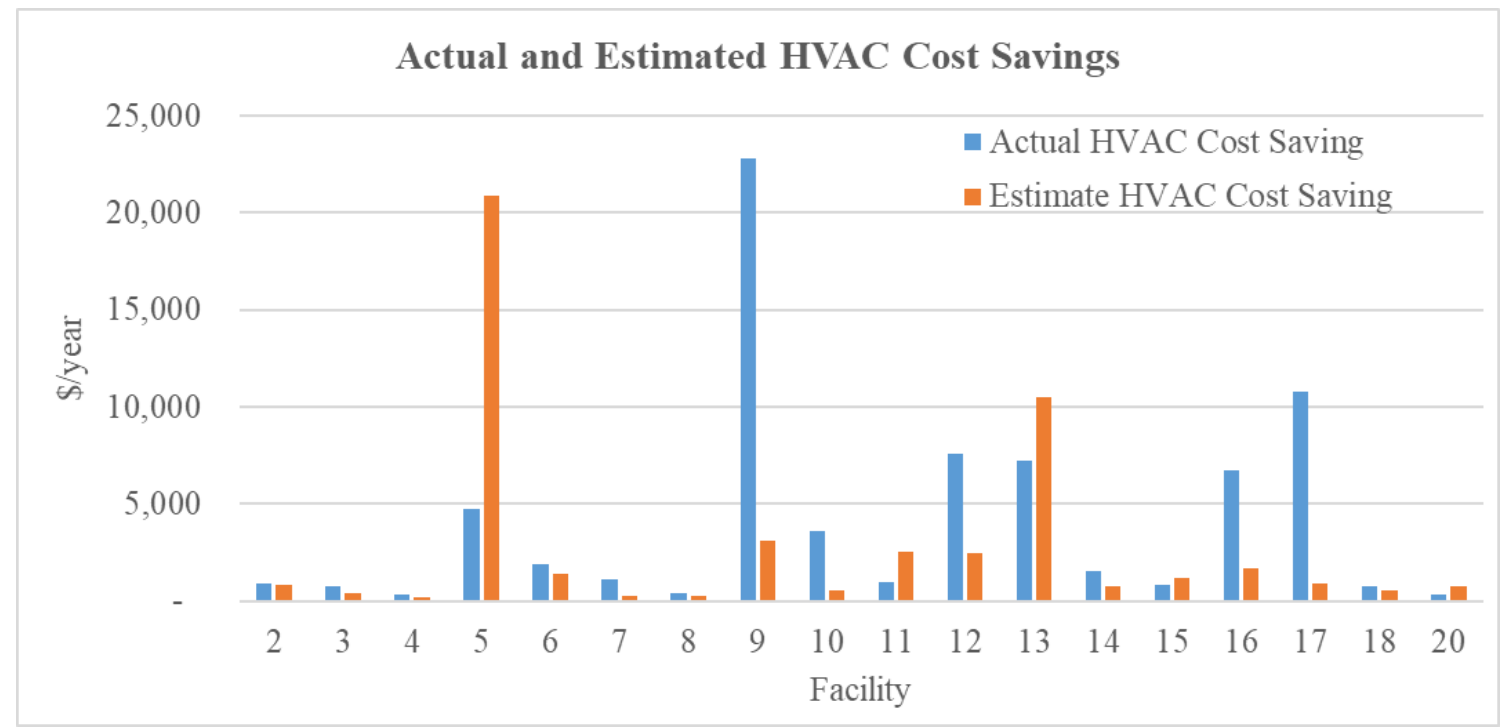

Figure 3.9:Actual and Estimated HVAC Cost Savings

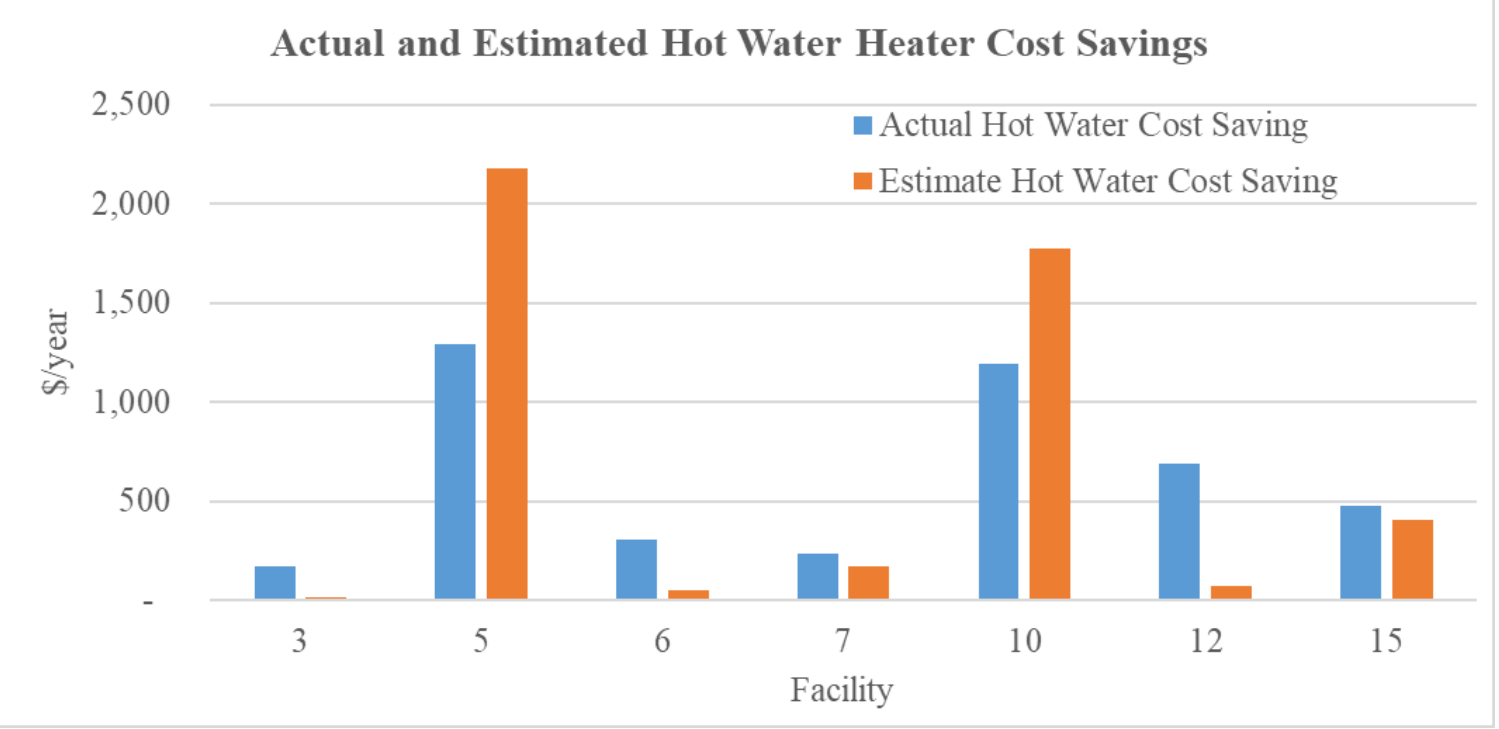

Figure 3.10:Actual and Estimated Hot Water Heater Cost Savings 


\subsubsection{Industrial Virtual Energy Audit Tool}

For the purposes of this study an industrial facility is defined as any facility whose operation falls between 311 to 339 of the North American Industry Classification System (NAICS) codes. The industrial processes are specific to the type of product being produced and the requirement of the energy systems for these processes vary significantly. Therefore, to recommend energy conservation measures, energy systems of a given industrial facility is divided into three categories: (1) Motor systems, (2) thermal and combustion systems supporting industrial processes and (3) buildings and grounds supporting office space and any non-industrial space like warehouse, loading \& unloading areas etc.

Due to the nature of industrial operations, types of fuels used for energy systems can be very diverse, like electricity, natural gas, butane, propane, saw dust etc. For the purposes of this study it is assumed that the facility just consumes two types of fuels i.e. electricity and natural gas.

\subsubsection{User Inputs and Model Outputs}

Table 3.13: User Inputs and Model Outputs

\begin{tabular}{|l|c|}
\hline \multicolumn{1}{|c|}{ User Inputs } & Model Outputs \\
\hline$\circ$ Industrial facility Type (i.e. & $\circ \quad$ Estimated current and proposed annual energy \\
NAICS code) & costs and possible energy conservation \\
\hline Area (in Square foot) & recommendations along with estimated annual \\
& cost savings for the following energy systems. \\
& $-\quad$ Motor Systems \\
& Combustion and Thermal Systems \\
& Buildings and Grounds \\
\hline
\end{tabular}




\section{Industrial Facility Type:}

Industrial facility type is one of the inputs for the commercial virtual energy audit tool with 5-digit, 4-digit or 3-digit NAICS code as the acceptable input. The dataset considered for analysis is mainly for industrial facilities falling between 311 to 339 of NAICS classification. For a full list of 3-digit NAICS accepted by the tool please refer to Appendix A-5.

\section{Area:}

Area is defined as, all the area where the manufacturing activity is taking place including interior and exterior locations, and areas where there are offices spaces, warehouses, etc. which support the primary activity of the facility. Area must be entered in square foot.

\subsubsection{Energy Systems:}

Once the user has provided the required inputs, the model estimates the values for annual energy and dollar values for existing and proposed scenarios of the pre-determined energy systems and recommend the possible energy conservation measures along with the estimated energy and dollar savings. Energy systems considered for developing energy conservation measures are
○ Motor Systems
○ Combustion and Thermal Systems
$\circ$ Buildings and Grounds

To explain the virtual audit tool, an imaginative facility which produces plastic products like dinner ware and cups (except foam) is considered. The following inputs were used for the imagined facility:

○ Industrial Facility Type : Plastic Product Manufacturing Facility

(NAICS Code: 326199) 
$\circ$ Area (in Sq. Ft) $\quad: 75,000$ Sq. Ft.

\subsubsection{Data Model}

Industrial Assessment Center (IAC) dataset is considered for building the industrial virtual energy audit tool as the data set has very comprehensive data points for various energy systems like pumps, motors, boilers, furnaces, HVAC, compressors, lighting etc.

Industrial Assessment Centers are located across the U.S. and are funded by Department of Energy to provide no-cost energy assessments to local small and mid-sized manufacturers that help to save energy, reduce waste and improve productivity. The IAC database covers wide variety of manufacturing processes and has a good number of sample data sets for various manufacturing processes and their associated energy systems.

To understand the IAC database structure, it is important to understand two cardinal terms, assessment and recommendation. If a facility gets an energy audit by the IAC team, then the energy audit is referred to as an assessment. Based on the observed operations and data collected during the assessment by the IAC team some improvements are suggested, these suggestions are called recommendations. Generally, IAC teams suggests recommendations for various aspects of the facilities operations like energy systems, waste minimization, improving productivity, etc. As the virtual audit tool is for energy systems only, the recommendations for energy systems with natural gas and electricity as an energy source are considered.

Data entries for assessment captures the characteristics of the facility. Each data entry may have multiple data points like plant area, NAICS code, annual electric consumption, type of product, no. of units produced, etc. For a detailed list of assessment data points definition please refer to Appendix B-1. Each assessment data entry has a unique ID associated with it, unique ID is at least 
5 characters in length with first two characters as alphabets, followed by numeric characters. Example of assessment ID is WV075. First two characters of the ID indicate the university which has conducted energy audit and next three characters indicate the count of energy audits done so far by that university. WV075 indicates the seventy fifth audit conducted by West Virginia University.

Data entries for recommendation captures the characteristics of that specific recommendation. Each assessment can have multiple recommendations associated with it and a recommendation data entry can have multiple data points. For example, if it is an energy conservation recommendation than it may contain data points like the amount of energy saved, cost savings, payback period, type of resource save, ARC code etc. For a detailed list of all recommendation data points definition please refer to Appendix B-2.

Recommendations also have two data points which serve special purpose of identification. One is assessment Id indicating to which assessment that recommendation belongs to. Second is a super ID which is a combination of assessment ID and the rank of the recommendation based on cost savings achieved. For example, a super ID can be like WV07501, meaning that the recommendation belongs to WV075 assessment and is ranked first based on cost savings achieved.

Assessment Recommendation Code (ARC) system is a system developed by the IAC to identify recommendation category. ARC system is a hierarchical system, with various levels for energy management, direct productivity enhancements and waste minimization / pollution prevention. Each level has multiple sub categories going down four more levels. As energy systems are the primary point of interest for the virtual audit tool, only data with ARC code 2 i.e. energy management systems were considered. ARC code 2 i.e. energy management systems has nine sub 
categories, but only four sub categories, 2.1, 2.2, 2.4 and 2.7 which are major contributors for energy consumption were considered.

A full list of ARC codes can be found on the IAC website. It should be noted that the data point that provide ARC code information in the recommendation data entries is an ARC2 code which is 5-digit number. To make it easier to understand and to use in the analysis, ARC code data from the pdf on the IAC website (as shown in Figure 3.6) is rearranged as shown in the Table 3.14.

There are many more terms related to the IAC database, all the terms are not explained here either because they are self-explanatory or not pertinent to the analysis being carried out.

IAC database uses codes for indicating the type of resource saved for a recommendation, EC for annual kWh conserved, E2 for annual NG conserved, etc. For full list of resource codes and names please refer to Appendix B-3. In assessment data entries, NAICS data point is a five-digit NAICS code. To make it easy to manipulate the data to make selection for the three or four-digit NAICS codes which are parent categories for five-digit NAICS code, a comprehensive NAICS codes table with three, four and five-digit NAICS codes data is added to the data model. 


\section{Energy Management}

\subsection{Combustion Systems}

2.11 FURNACES, OVENS \& DIRECTLY FIRED OPERATIONS

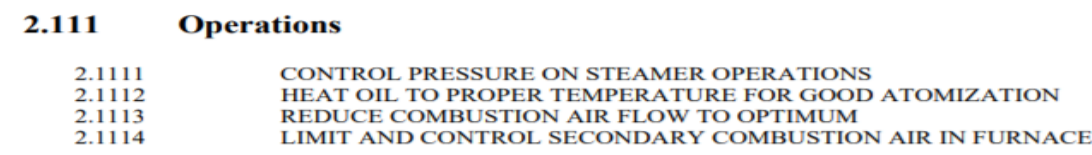

Figure 3.11: ARC Codes Format on IAC Website [31]

Table 3.14: Sample IAC Database Assessment Recommendation Code (ARC) system Classification

\begin{tabular}{|c|c|c|c|c|c|c|c|c|c|}
\hline $\begin{array}{c}\mathrm{ARC} \\
\mathrm{C} 1\end{array}$ & ARC C1 Name & $\begin{array}{c}\mathrm{ARC} \\
\mathrm{C} 2\end{array}$ & $\begin{array}{l}\text { ARC C2 } \\
\text { Name }\end{array}$ & $\begin{array}{c}\mathrm{ARC} \\
\mathbf{C 3}\end{array}$ & ARC C3 Name & $\begin{array}{c}\mathrm{ARC} \\
\mathrm{C4}\end{array}$ & C4 Name & ARC2 & ARC2 Name \\
\hline 2 & $\begin{array}{c}\text { ENERGY } \\
\text { MANAGEMENT }\end{array}$ & 2.1 & $\begin{array}{l}\text { Combustion } \\
\text { Systems }\end{array}$ & 2.11 & $\begin{array}{c}\text { FURNACES, } \\
\text { OVENS \& } \\
\text { DIRECTLY FIRED } \\
\text { OPERATIONS }\end{array}$ & 2.111 & Operations & 2.1111 & $\begin{array}{c}\text { CONTROL } \\
\text { PRESSURE ON } \\
\text { STEAMER } \\
\text { OPERATIONS } \\
\end{array}$ \\
\hline 2 & $\begin{array}{c}\text { ENERGY } \\
\text { MANAGEMENT }\end{array}$ & 2.2 & $\begin{array}{l}\text { Thermal } \\
\text { Systems }\end{array}$ & 2.25 & $\begin{array}{c}\text { HEAT } \\
\text { CONTAINMENT }\end{array}$ & 2.251 & Insulation & 2.2511 & $\begin{array}{c}\text { INSULATE BARE } \\
\text { EQUIPMENT }\end{array}$ \\
\hline 2 & $\begin{array}{c}\text { ENERGY } \\
\text { MANAGEMENT }\end{array}$ & 2.4 & $\begin{array}{l}\text { Motor } \\
\text { Systems }\end{array}$ & 2.41 & MOTORS & 2.415 & $\begin{array}{c}\text { Motor } \\
\text { Maintenance } \\
\text { / Repair }\end{array}$ & 2.4151 & $\begin{array}{c}\text { DEVELOP A } \\
\text { REPAIR/REPLAC } \\
\text { E POLICY }\end{array}$ \\
\hline 2 & $\begin{array}{c}\text { ENERGY } \\
\text { MANAGEMENT }\end{array}$ & 2.7 & $\begin{array}{l}\text { Building and } \\
\text { Grounds }\end{array}$ & 2.71 & LIGHTING & 2.713 & Controls & 2.7135 & $\begin{array}{c}\text { INSTALL } \\
\text { OCCUPANCY } \\
\text { SENSORS }\end{array}$ \\
\hline
\end{tabular}


The data of assessments, recommendations, NAICS codes and ARC codes are connected to build a comprehensive data model, a schematic of the model can be seen in Figure 3.7. Industrial virtual energy audit tool was built in Excel $^{\circledR}$, as spreadsheet-based data analytics tool. Keeping in view of the system performance and responsiveness of the tool, only data for years from 2003 to 2016 is considered for analysis from the IAC database.

Data entry process for the IAC database is robust and structure of the data was found to be very good, needing no data cleaning. After all the data is ready and is connected with other datasets, required measures are calculated.

The energy use index (EUI) for a facility belonging to a given NAICS category is calculated as following

$\mathrm{Kwh} / \mathrm{yr} / \mathrm{Sq} . \mathrm{Ft} \quad=\frac{\text { Sum of annual } \mathrm{Kwh} \text { for all faclities with a given NAICS Code }}{\text { Sum of Sq.Ft for all facilites with a given NAICS code }}$

\section{Error! Bookmark not defined.Error! Bookmark not defined.}

$\mathrm{MMBtu} / \mathrm{yr} / \mathrm{Sq} . \mathrm{Ft}=\frac{\text { Sum of annual MMBtu for all faclities with a given NAICS Code }}{\text { Sum of Sq.Ft for all facilites with a given NAICS code }}$

\section{$\underline{\text { Example }}$}

The imaginative facility taken as an example has an area of 75,000 Sq. Ft and belongs to 326199 NAICS category.

From the data model, facilities with similar operations i.e. facilities which fall under NAICS 326199 category consume $68.254 \mathrm{kWh} / \mathrm{yr} / \mathrm{Sq} . \mathrm{Ft}$ and $0.089 \mathrm{MMBtu} / \mathrm{yr} / \mathrm{Sq} . \mathrm{Ft}$. These values are calculated based on equation 1 and 2 . Therefore, estimated annual energy usage for the imagined facility can be calculated as follows 


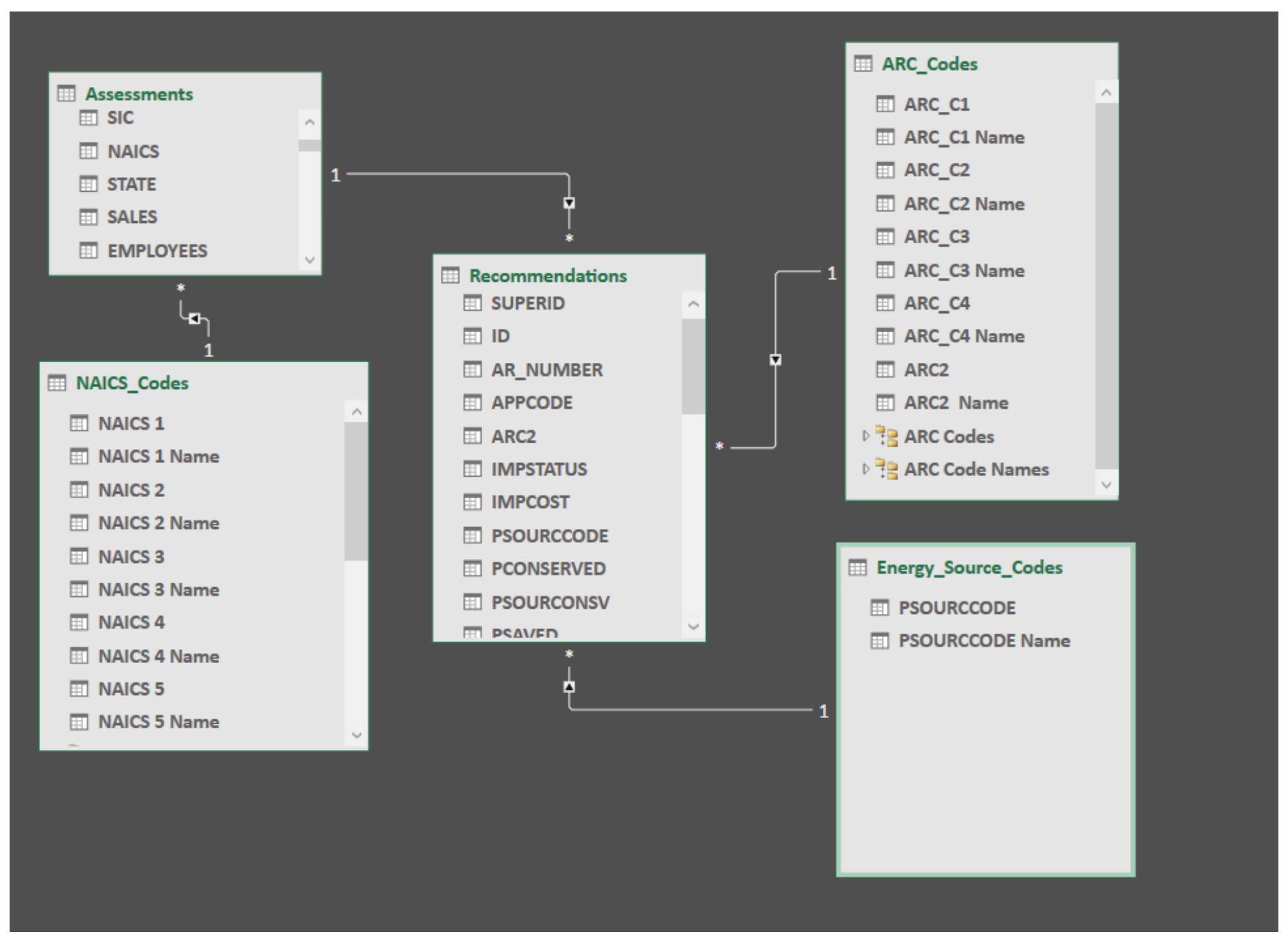

Figure 3.12: Data Model for Industrial Virtual Audit tool 
Annual Electricity Usage (kWh/yr)

$=$ Area $\times 68.254 \mathrm{kWh} / \mathrm{yr} / \mathrm{Sq} . \mathrm{Ft}$

$=75,000 \mathrm{Sq} . \mathrm{Ft} \times 68.254 \mathrm{kWh} / \mathrm{yr} / \mathrm{Sq} . \mathrm{Ft}$

$=5,119,068 \mathrm{kWh} /$ year.

Annual NG Usage (MMBtu/yr)

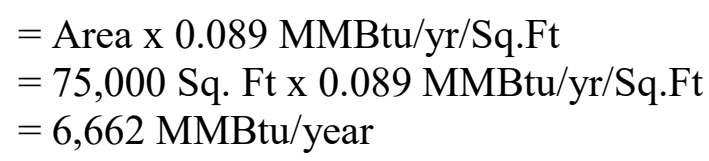

After the facility annual energy usage for electricity and natural gas was calculated, percent of possible electric and natural gas savings were calculated based on the historical assessment and recommendation data for the energy systems under consideration.

Percent savings for a different energy system area calculated as following

$\% \mathrm{kWh}$ Savings for Motor Systems

Sum of annual Kwh savings for all faclities with a given NAICS Code and falling under ARC code 2.4 Sum of annual Kwh usage for all faclities with a given NAICS Code

\% MMBtu Savings for Motor Systems

Sum of annual MMBtu savings for all faclities with a given NAICS Code and falling under ARC code 2.4 Sum of annual MMBtu usage for all faclities with a given NAICS Code

$\% \mathrm{kWh}$ Savings for Combustion and Thermal Systems

Sum of annual Kwh savings for all faclities with a given NAICS Code and falling under ARC code $2.1 \& 2.2$ Sum of annual Kwh usage for all faclities with a given NAICS Code 
\% MMBtu Savings for Combustion and Thermal Systems

Sum of annual MMBtu savings for all faclities with a given NAICS Code and falling under ARC code $2.1 \& 2.2$ Sum of annual MMBtu usage for all faclities with a given NAICS Code

$\% \mathrm{kWh}$ Savings for Buildings and Grounds

Sum of annual Kwh savings for all faclities with a given NAICS Code and falling under ARC code 2.7

Sum of annual Kwh usage for all faclities with a given NAICS Code

\% MMBtu Savings for Buildings and Grounds

Sum of annual MMBtu savings for all faclities with a given NAICS Code and falling under ARC code 2.7 Sum of annual MMBtu usage for all faclities with a given NAICS Code

\section{Example}

The imaginative facility taken as an example has an area of 75,000 Sq. Ft and belongs to 326199 NAICS category, and is estimated to be consuming 5,119,068 kWh of electricity and 6,622 MMBtu of Natural Gas annually. Combustion and Thermal energy systems are considered here as an example to illustrate the savings calculations.

As discussed earlier industrial processes and the energy systems associated with the processes are complex, so energy conservation measures (ECM) recommended are most common ones which are applicable to a wide range of thermal and combustion systems 
For a given facilities thermal and combustion systems the following energy conservation measures can be implemented

- Recovery Boiler Condensate

- Flue Gas - Recuperation

- Adjust Air to Fuel Ratio

- Insulate Hot Surfaces to Avoid Heat Loss

- Fix steam leaks, etc.

Based on equation 5 and 6 , percent $\mathrm{kWh}$ and natural gas possible from combustion and thermal is found to be $1.578 \%$ and $9.234 \%$ respectively, so annual electric and natural gas savings possible by implementing the possible energy conservation measures can be estimated as follows.

Combustion and Thermal Energy systems energy savings

Annual $\mathrm{kWh}$ savings $\quad=\% \mathrm{kWh}$ savings possible $\mathrm{x}$ Estimated Annual $\mathrm{kWh}$

$=1.578 \%$ x $5,119,068 \mathrm{kWh} / \mathrm{yr}$

$=80,785 \mathrm{kWh} / \mathrm{yr}$.

Annual MMBtu savings $\quad=\%$ MMBtu savings possible $\mathrm{x}$ Estimated Annual MMBtu

$=9.234 \%$ x $6,662 \mathrm{MMBtu} / \mathrm{yr}$

$=615 \mathrm{MMBtu} / \mathrm{yr}$.

Electricity and natural gas costs were estimated based on the assessments done in the state of WV.

This can be easily modified using costs for other state or whole of U.S.

$\$ / \mathrm{kWh}=\frac{\text { Sum of annual Kwh cost for all faclities in state of } W V}{\text { Sum of annual Kwh usage for all faclities in state of } W V}$

$\$ /$ MMBtu $=\frac{\text { Sum of annual MMBtu cost for all faclities in state of } W V}{\text { Sum of annual MMBtu usage for all faclities in state of } W V}$ 
From data model based on equation 9 and 10, energy costs for electricity and natural gas costs for state of WV can were estimated to be $\$ 0.0321 / \mathrm{kWh}$ and $\$ 7.175 / \mathrm{MMBtu}$.

Cost savings possible from combustion and thermal systems by implementing the possible energy conservation measures can be estimated as follows.

Combustion and Thermal Energy systems energy cost savings

Annual $\mathrm{kWh}$ cost savings $\quad=$ Annual $\mathrm{kWh}$ savings $\mathrm{x} \$ / \mathrm{kWh}$

$=80,785 \mathrm{kWh} / \mathrm{yr} \times \$ 0.0321 / \mathrm{kWh}$

$=\$ 2,593 / \mathrm{yr}$.

Annual MMBtu cost savings $=$ Annual MMBtu savings $\mathrm{x} \$ /$ MMBtu

$=615 \mathrm{MMBtu} / \mathrm{yr} \times \mathbf{\$}$ 7.175/MMBtu

$=\$ 4,413 / \mathrm{yr}$.

Total energy cost savings for Combustion and Thermal Energy systems is estimated as following

Annual cost savings $\quad=$ Annual $\mathrm{kWh}$ cost savings + Annual MMBtu cost savings

$=\$ 2,593 / \mathrm{yr}+\$ 4,413 / \mathrm{yr}$

$=\$ 7,006 / \mathrm{yr}$

Savings for all the energy systems under consideration are calculated and are given in Table 3.15.

Current and proposed energy costs are also calculated.

It is assumed that the current and proposed energy costs are proportional to the energy savings possible, so the current energy costs for the energy systems are estimated as shown below

Combustion and Thermal Energy systems current energy costs

Current Annual kWh cost is estimated as following

$\frac{\% \mathrm{kWh} \text { of savings for Combustion \& Thermal Systems }}{\text { Sum of \% kWh of savings for all three systems }} x$ Annual Electricity Usage $\left(\frac{k W h}{y r}\right) \times \frac{\$}{k W h}$

Current Annual NG cost is estimated as following 
$\frac{\% \text { MMBtu of savings for Combustion \& Thermal Systems }}{\text { Sum of } \% \mathrm{kWh} \text { of savings for all three systems }} x$ Annual NG Usage $\left(\frac{\text { MMBtu }}{y r}\right) x \frac{\$}{\text { MMBtu }}$

Based on equations 11 and 12 and, current energy costs for combustion and thermal energy systems can be estimated as follows.

Combustion and Thermal Energy systems current energy costs

$$
\begin{aligned}
\text { Current Annual kWh cost } & =\frac{1.5 \%}{5 \%+1.58 \%+2.53 \%} \times 5,119,068 \frac{\mathrm{kWh}}{\mathrm{yr}} \times \frac{\$ 0.0321}{k W h} \\
& =\$ 28,481 / \mathrm{yr}
\end{aligned}
$$

$$
\begin{aligned}
\text { Current Annual MMBtu cost } & =\frac{9.23 \%}{0.08 \%+9.23 \%+3.60 \%} \times 6,662 \frac{\mathrm{MMbtu}}{\mathrm{yr}} \times \frac{\$ 7.175}{M M B t u} \\
& =\$ 34,170 / \mathrm{yr} .
\end{aligned}
$$

Total current energy cost for Combustion and Thermal Energy systems is estimated as following

$$
\begin{array}{ll}
\text { Current Annual costs } & =\text { Current Annual } \mathrm{kWh} \text { cost }+ \text { Current Annual MMBtu cost } \\
& =\$ 28,481 / \mathrm{yr}+\$ 34,170 / \mathrm{yr} \\
& =\$ 62,651 / \mathrm{yr}
\end{array}
$$

Combustion and Thermal Energy systems proposed energy costs are calculated as follows

$$
\begin{aligned}
\text { Proposed Annual kWh cost } & =\text { Current Annual costs }- \text { Annual cost savings } \\
& =\$ 62,651 / \mathrm{yr}-\$ 7,006 / \mathrm{yr} \\
& =\$ 55,645 / \mathrm{yr}
\end{aligned}
$$

Similarly, energy cost savings, current and proposed energy costs are estimated for motor systems and building and grounds for a facility with 75,00 Sq. Ft and falls under NAICS 326199 category (Table 3.15). 
Table 3.15: Energy Cost Savings for an Industrial Facility

\begin{tabular}{|c|c|c|c|c|c|c|c|}
\hline S.No & $\begin{array}{l}\text { Energy } \\
\text { Systems }\end{array}$ & $\begin{array}{c}\text { Possible } \\
\text { Recommendation }\end{array}$ & $\begin{array}{l}\% \mathrm{kWh} \\
\text { Savings }\end{array}$ & $\begin{array}{l}\% \text { MMBtu } \\
\text { Savings }\end{array}$ & $\begin{array}{c}\text { Current } \\
\text { Energy Costs } \\
(\$ / y r) \\
\end{array}$ & $\begin{array}{c}\text { Proposed } \\
\text { Energy Costs } \\
(\$ / y r) \\
\end{array}$ & Savings (\$/yr) \\
\hline 1 & $\begin{array}{l}\text { Motor } \\
\text { Systems }\end{array}$ & $\begin{array}{l}\text { Establish Replace/Rewind } \\
\text { Policy for Motors, Use of } \\
\text { VFD's on Motors \& } \\
\text { Pumps, Compressor } \\
\text { Controls, Sequencer etc. }\end{array}$ & $5.00 \%$ & $0.08 \%$ & 90,479 & 82,234 & 8,245 \\
\hline 2 & $\begin{array}{c}\text { Combustion } \\
\text { and } \\
\text { Thermal } \\
\text { Systems }\end{array}$ & $\begin{array}{c}\text { Recovery Boiler } \\
\text { Condensate, Flue Gas - } \\
\text { Recuperation, Air to Fuel } \\
\text { Ratio, Insulate Hot } \\
\text { Surfaces to Avoid Heat } \\
\text { Loss, Fix steam leaks, etc. }\end{array}$ & $1.58 \%$ & $9.23 \%$ & 62,651 & 55,645 & 7,006 \\
\hline 3 & $\begin{array}{l}\text { Building } \\
\text { and } \\
\text { Grounds }\end{array}$ & $\begin{array}{l}\text { Upgrade Lighting to LED } \\
\text { \& Install Occupancy } \\
\text { Sensors, Retrofit HVAC } \\
\text { units with Economizer, } \\
\text { Multi-Speed Supply Fan, } \\
\text { Demand-Controlled } \\
\text { Ventilation [DCV] etc. }\end{array}$ & $2.53 \%$ & $3.60 \%$ & 58,911 & 53,041 & 5,870 \\
\hline Total & - & - & - & - & $\$ 212,041 / y r$ & $\$ 190,920 / y r$ & $\$ 21,121 / y r$ \\
\hline
\end{tabular}


A computer program was developed to generate information shown in Table 3.15. The Graphical User Interface (GUI) of the program shown in Figure 3.8. The program output is shown in Figure 3.9 .

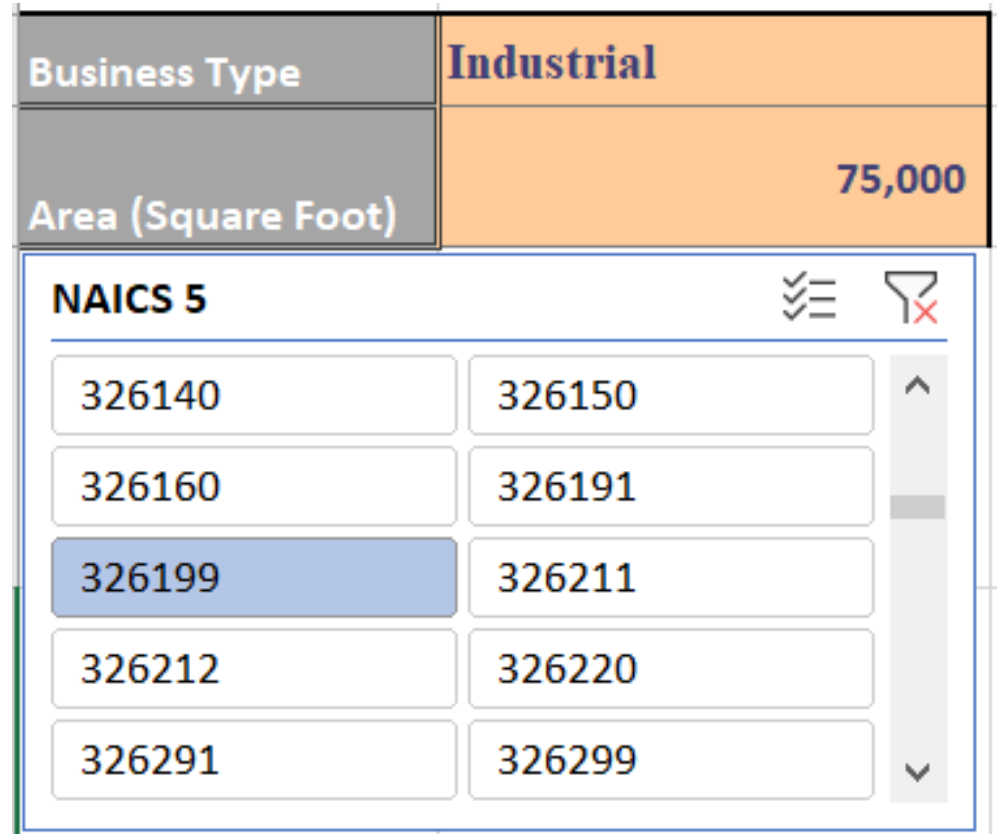

Figure 3.13: GUI for the Industrial Virtual Energy Audit program 


\section{Dear Business Owner:}

Our team at WVU has performed a virtual energy audit for your business, Here are some key findings

- Based on energy per sq. $\mathrm{ft}$ it is estimated that your facility consumes $5119068 \mathrm{kWh} / \mathrm{yr}$ and $6662 \mathrm{MMBtu} / \mathrm{yr}$.

- Your facility can save around \$21121per year in energy costs by implementing the energy efficient technologies ( see table below for additional information)

Potential Energy Saving Opportunites

\begin{tabular}{|c|c|c|c|c|c|}
\hline S.No & Energy Systems & Possible Recommendation & $\begin{array}{c}\text { Current } \\
\text { Energy Costs } \\
\text { (\$/yr) }\end{array}$ & $\begin{array}{c}\text { Proposed } \\
\text { Energy Costs } \\
(\$ / y r)\end{array}$ & $\begin{array}{c}\text { Savings } \\
(\$ / y r)\end{array}$ \\
\hline & Motor Systems & $\begin{array}{l}\text { Establish Replace/Rewind Policy for } \\
\text { Motors, Use of VFD's on Motors \& } \\
\text { Pumps, Compressor Controls, Sequencer } \\
\text { etc. }\end{array}$ & 90,479 & 82,234 & $\$ 8,245$ \\
\hline & $\begin{array}{l}\text { Combustion and } \\
\text { Thermal } \\
\text { Systems }\end{array}$ & $\begin{array}{l}\text { Recover Boiler Condesnate, Flue Gas - } \\
\text { Recuperation, Air to Fuel Ratio, Insulate } \\
\text { Hot Surfaces to Avoid Heat Loss, Fix } \\
\text { steam leaks, etc. }\end{array}$ & 62,651 & 55,645 & $\$ 7,006$ \\
\hline & $\begin{array}{l}\text { Building and } \\
\text { Grounds }\end{array}$ & $\begin{array}{l}\text { Upgrade Lighting to LED \& Install } \\
\text { Occupancy Sensors, Retrofit HVAC } \\
\text { units with Economizer, Multi-Speed } \\
\text { Supply Fan, Demand-Controlled } \\
\text { Ventilation [DCV] etc. }\end{array}$ & 58,911 & 53,041 & \$ 5,870 \\
\hline Total & - & - & $\$ \quad 212,041$ & $\$ \quad 190,920$ & $\$ 21,121$ \\
\hline
\end{tabular}

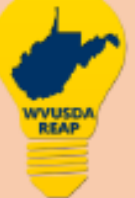

We can make your business energy efficient, Please visit us at https://industrialassessmentcenter.wvu.edu/

Figure 3.14: Output provided by the Industrial Virtual Energy Audit program. 


\subsection{Survey Methodology}

The next phase of this study was focused on comparing effectiveness of virtual audit-based marketing strategy with traditional leaflet-based marketing strategy in promoting an energy audit program that is funded by United States Department of Agriculture (USDA). A paper-based survey was conducted using regular mail to carry out the comparison. Two types of mail packages were used to conduct the survey are shown in Table 3.16.

Table 3.16: Two Types of Packages Used for Conducting Survey Study

\begin{tabular}{|l|l|l|}
\hline & \multicolumn{1}{|c|}{$\begin{array}{c}\text { Packet 1 } \\
\text { (leaflet-based methods) }\end{array}$} & \multicolumn{1}{c|}{$\begin{array}{c}\text { Packet 2 } \\
\text { (virtual audit-based methods) }\end{array}$} \\
\hline $\begin{array}{l}\text { WVU Institutional Review } \\
\text { Board (IRB) Cover Letter and } \\
\text { basic instructions }\end{array}$ & Included & Included \\
\hline Pre- Survey Questionnaire & Included & Included \\
\hline Brochure & $\begin{array}{l}\text { Leaflet with basic } \\
\text { information about the USDA } \\
\text { energy audit program }\end{array}$ & $\begin{array}{l}\text { Leaflet with basic information } \\
\text { about the USDA energy audit } \\
\text { program and outputs of virtual } \\
\text { audit }\end{array}$ \\
\hline Post- Survey Questionnaire & Included & Included \\
\hline
\end{tabular}

First page of the mail packet was WVU IRB cover letter which outlines the intent of the research and informs the participant that their participation is voluntary. Copy of WVU IRB cover letter is included in Appendix C:. Second page of the mail packet had instructions to aid through the process, for a copy of survey instructions please see Appendix C-2. Third page of the mail packet contained survey questionnaire.

The questionnaire was prepared with an intent to gauge and understand the businesses' interest in conserving energy at their facility and to judge their interest in getting an energy audit done.

Following five questions were included in the questionnaire: 
I. Are you conscious of your facilities energy usage (do you check monthly utility bills etc.)?

i) Yes

ii) No

II. Do you adjust or switch off energy equipment when not in use (Switching off lights, setback temperature etc.)?

i) Yes

ii) No

III. Did you think about replacing your equipment (e.g. old water heater etc.) with energy efficient ones in the recent times?

i) Yes

ii) $\mathrm{No}$

IV. Do you want to get an energy audit done at your facility now or in the near future?

i) Yes

ii) No

If yes for question IV, please answer following questions

iii) Do you have any difficulties regarding?

(1) Technological Assistance

(a) Yes

(b) No

(2) Funding Assistance

(a) Yes

(b) No

First question was aimed to gauge how conscious a facility is about its energy use. For example, does the facility personnel check utility bills periodically, and keep a tab on any deviations from regular trends etc.

Second question was prepared keeping in mind that, if a facility is conscious about their energy use, then, are they doing anything about it, either making an attempt to control or reduce the energy consumption. For example, does the facility personnel switch off lights when not needed, does the facility set back HVAC temperature set points when facility is not in operation etc. 
Third question was prepared keeping in mind that, if a facility is really doing something to reduce their energy consumption, then, have they tried to replace any old equipment with the energy efficient ones to reduce their energy consumption. Third question also serves another purpose to understand whether if a facility has recently replaced old equipment. If it has, then it may indicate that the facility recently had an energy audit or at least had few energy projects. If a facility answered no for question 4 then one reason for such response could be that the facility recently had an energy audit or energy projects.

Fourth question was drafted to capture the intent of the facility to get an energy audit at their facility now or in the near future.

Sub questions within question four were asked to understand the awareness of the facilities across the state of WV about the resources available to them in the context of energy efficiency.

In the brochure for the leaflet-based method, basic information about the USDA energy audit program was included (Figure 3.11). In the brochure for the virtual audit-based method, the basic information about the USDA energy audit program and output generated by virtual audit tool was also included (Figure 3.12)

In the last page of the mail packet i.e. fifth page for traditional method mail packet and sixth page for virtual method mail packet, participant was asked to re-respond to the question number four. This was done to check the effect of leaflet vs virtual audit on their willingness to participate in a virtual audit program. To see a complete mail packet for traditional and virtual methodologies please refer to Appendix C-3 and Appendix C-4 respectively. A comparison of leaflet methods and virtual method mail packets is shown in Table 3.17. 
Table 3.17: Comparison of Leaflet Methods and Virtual method Mail Packet

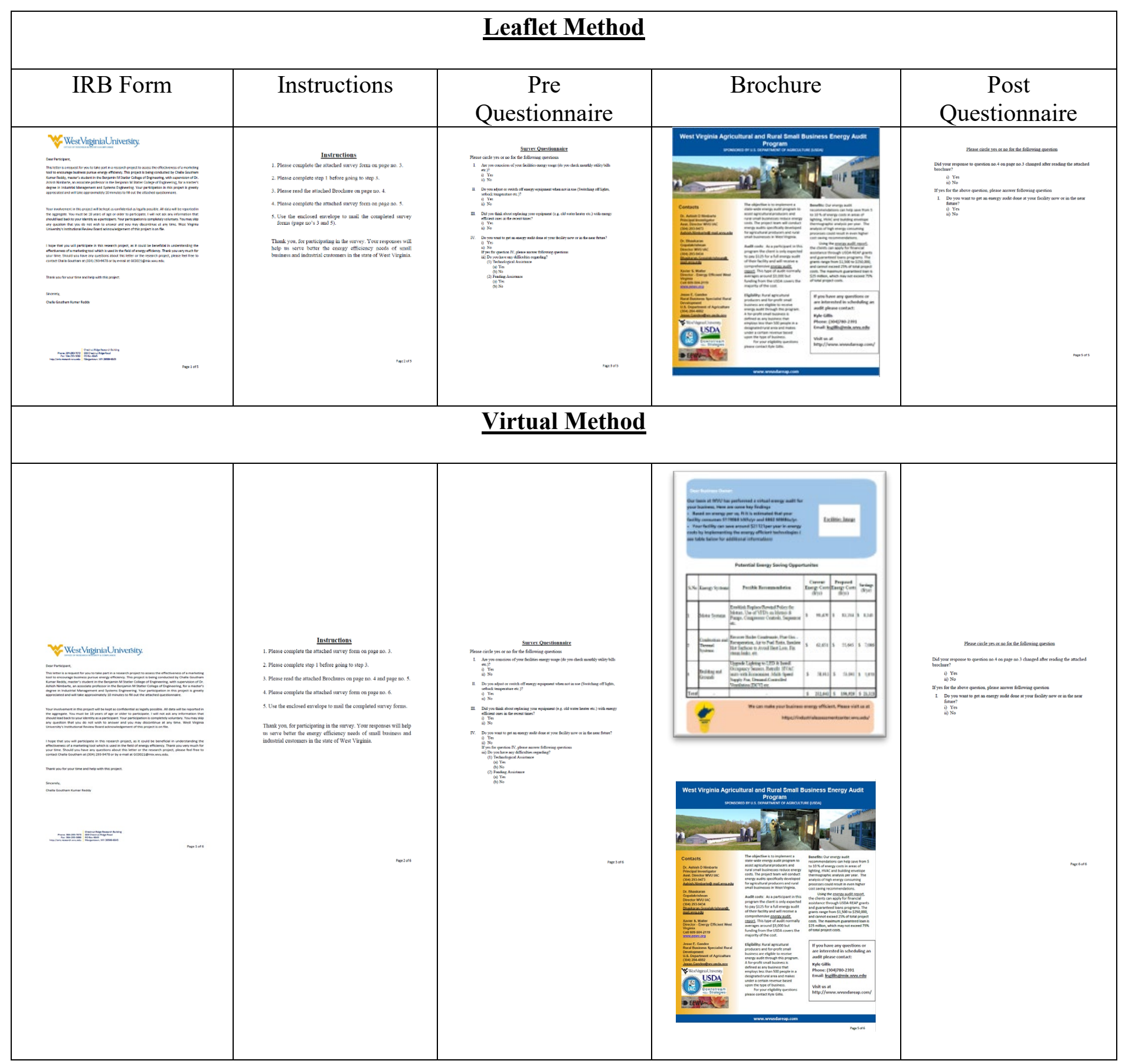


The survey packets were mailed to various commercial and industrial businesses across the state of West Virginia, businesses were selected at random. A total of 200 businesses across the state of WV were requested to participate in the survey. 180 surveys were sent in mail, and 20 surveys we handed out in persons. Out of total 200 surveys, hundred used traditional brochure method and other hundred used virtual brochure method. Locations to which the surveys were mailed or handed out are shown Figure 3.10. Detailed breakdown of sample used for the surveys is shown in Table 3.18.

Table 3.18: Distribution of Surveys by Marketing Method and Business Type

\begin{tabular}{|l|c|c|c|}
\hline \multirow{2}{*}{ Business Type } & \multicolumn{2}{|c|}{ Brochure Type } & \multirow{2}{*}{ Total } \\
\cline { 2 - 3 } & Traditional Method & Virtual Method & \\
\hline Commercial & 76 & 76 & 152 \\
\hline Industrial & 24 & 24 & 48 \\
\hline Total & $\mathbf{1 0 0}$ & $\mathbf{1 0 0}$ & $\mathbf{2 0 0}$ \\
\hline
\end{tabular}

Facilities to which surveys were sent in mail were asked to send their responses using an enclosed envelope which had return address and paid postage stamp. For businesses to which surveys were given in person were asked to fill out the survey forms during the visit, but if the participants wanted to fill out the survey at a later time, then an envelope with a return address and postage were given to the participants. 


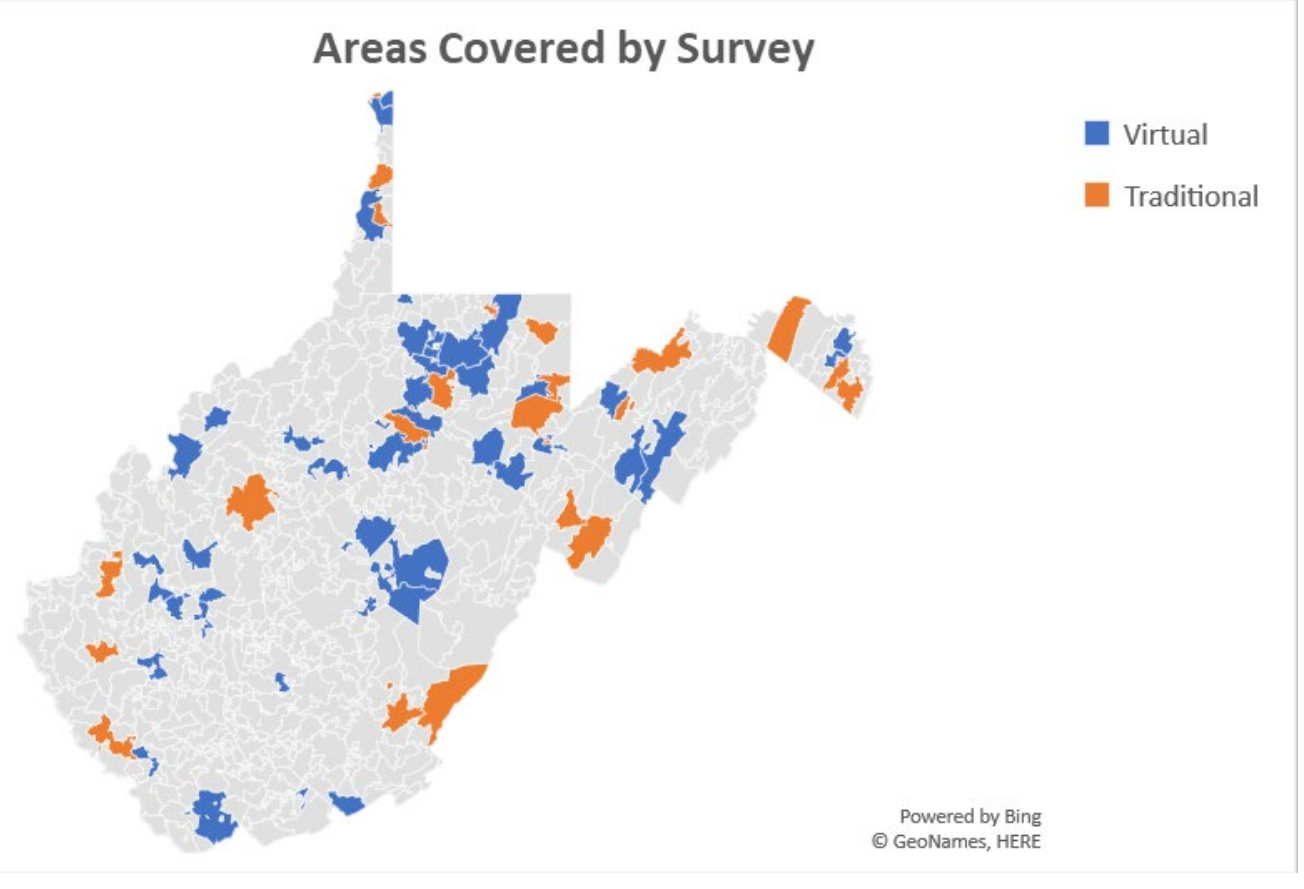

Figure 3.15: Locations Covered by the Survey 
West Virginia Agricultural and Rural Small Business Energy Audit Program

SPONSORED BY U.S. DEPARTMENT OF AGRICULTURE (USDA)

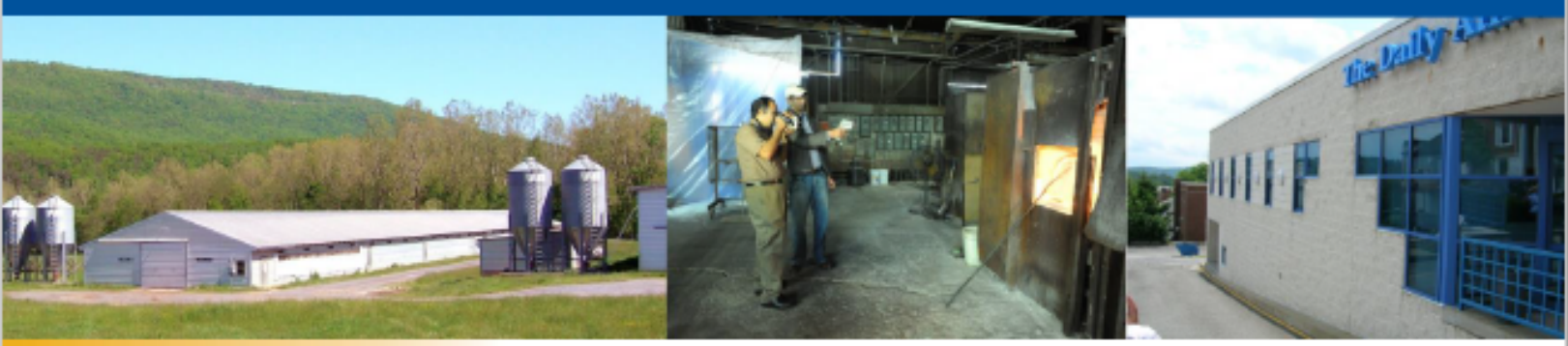

\section{Contacts}

Dr. Ashish D Nimbarte Principal Investigator

Asst. Director WVU IAC

(304) 293-9473

Ashish.Nimbarte@ mail.wru.edu

Dr. Bhaskaran

Gopalakrishnan

Director WVU IAC

(304) 293-9434

Bhaskaran.Gopalakrishnan@ mail.wvunedu

Xavier S. Walter

Director - Energy Efficient West

Virginia

Cell 609-504-2119

www.eewv.org

Jesse E. Gandee

Rural Business Specialist Rural

Development

U.S. Department of Agriculture (304) 284-4882

Jesse.Gandeefowr.usdangov

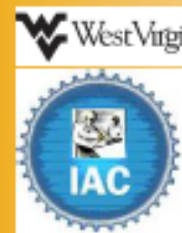

USDA

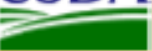

Downstream cE Strategies ।

EEWV-
The objective is to implement a state-wide energy audit program to assist agricultural producers and rural small businesses reduce energy costs. The project team will conduct energy audits specifically developed for agricultural producers and rural small businesses in West Virginia.

Audit costs: As a participant in this program the client is only expected to pay $\$ 125$ for a full energy audit of their facility and will receive a comprehensive energy audit report. This type of audit normally averages around $\$ 3,000$ but funding from the USDA covers the majority of the cost.

Eligibility: Rural agricultural producers and for-profit small business are eligible to receive energy audit through this program. A for-profit small business is defined as any business that employs less than 500 people in a designated rural area and makes under a certain revenue based upon the type of business.

For your eligibility questions please contact Kyle Gillis.
Benefits: Our energy audit recommendations can help save from 5 to $10 \%$ of energy costs in areas of lighting, HVAC and building envelope thermographic analysis per year. The analysis of high energy consuming processes could result in even higher cost saving recommendations.

Using the energy audit report, the clients can apply for financial assistance through USDA-REAP grants and guaranteed loans programs. The grants range from $\$ 1,500$ to $\$ 250,000$, and cannot exceed $25 \%$ of total project costs. The maximum guaranteed loan is $\$ 25$ million, which may not exceed $75 \%$ of total project costs.

If you have any questions or are interested in scheduling an audit please contact:

Kyle Gillis

Phone: (304)780-2391

Email: ksgillis@mix.wvu.edu

Visit us at

http://www.wvusdareap.com/ 


\section{Dear Business Owner:}

Our team at WVU has performed a virtual energy audit for your business, Here are some key findings

- Based on energy per sq. $\mathrm{ft}$ it is estimated that your facility consumes $5119068 \mathrm{kWh} / \mathrm{yr}$ and $6662 \mathrm{MMBtu} / \mathrm{yr}$.

- Your facility can save around \$21121per year in energy costs by implementing the energy efficient technologies ( see table below for additional information)

\section{$\underline{\text { Facilities Image }}$}

Potential Energy Saving Opportunites

\begin{tabular}{|c|c|c|c|c|c|}
\hline S.No & Energy Systems & Possible Recommendation & $\begin{array}{c}\text { Current } \\
\text { Energy Costs } \\
(\$ / y r)\end{array}$ & $\begin{array}{c}\text { Proposed } \\
\text { Energy Costs } \\
(\$ / y r)\end{array}$ & $\begin{array}{c}\text { Savings } \\
\text { (\$/yr) }\end{array}$ \\
\hline 1 & Motor Systems & $\begin{array}{l}\text { Establish Replace/Rewind Policy for } \\
\text { Motors, Use of VFD's on Motors \& } \\
\text { Pumps, Compressor Controls, Sequencer } \\
\text { etc. }\end{array}$ & 90,479 & 82,234 & $\$ 8,245$ \\
\hline 2 & $\begin{array}{l}\text { Combustion and } \\
\text { Thermal } \\
\text { Systems }\end{array}$ & $\begin{array}{l}\text { Recover Boiler Condesnate, Flue Gas - } \\
\text { Recuperation, Air to Fuel Ratio, Insulate } \\
\text { Hot Surfaces to Avoid Heat Loss, Fix } \\
\text { steam leaks, etc. }\end{array}$ & 62,651 & 55,645 & s 7,006 \\
\hline 3 & $\begin{array}{l}\text { Building and } \\
\text { Grounds }\end{array}$ & $\begin{array}{l}\text { Upgrade Lighting to LED \& Install } \\
\text { Occupancy Sensors, Retrofit HVAC } \\
\text { units with Economizer, Multi-Speed } \\
\text { Supply Fan, Demand-Controlled } \\
\text { Ventilation [DCV] etc. }\end{array}$ & 58,911 & 53,041 & S 5,870 \\
\hline Total & - & - & $\$ \quad 212,041$ & $\$ \quad 190,920$ & $\$ 21,121$ \\
\hline
\end{tabular}

We can make your business energy efficient, Please visit us at https://industrialassessmentcenter.wvu.edu/

Figure 3.17: Virtual Brochure 


\section{Results and Discussion}

\subsection{Survey Results}

A total of twenty participants have responded to the survey, which is $10 \%$ of the sample size. Out of twenty responses, eleven were for virtual audit-based method and nine were for traditional leaflet-based method, with $11 \%$ and $9 \%$ response rates, respectively. Participants answered set of four questions mentioned earlier before reading the brochure.

In response to question one and two, most of the participants have said that they are conscious of their facility's energy usage and costs and are taking actions to reduce the energy consumption of their facility by adjusting or switching off energy equipment when not in use (Switching off lights, setback temperature etc.). As shown in Figure 4.1 and Figure 4.2, 95\% i.e. nineteen out of the twenty respondents have responded yes to question 1 and question 2 . Out of the twenty participants one participant answered yes to question 1 and no to question 2, and another participant answered no to question 1 and yes to question 2, rest of the participants have answered yes to question 1 and 2.

In response to question 3, as shown in Figure 4.3, 85\% of the participants have said that they have replaced or planning to replace the old energy consuming equipment with energy efficient ones. Out of the twenty participants three participants have answered no to question 3 . But all three participants who have answered no to question 3 have said that they are conscious of their facility's energy usage and are acting to reduce or adjust their energy consumption equipment when not in use. 
Q1: Are Facilites Conscious of Their Energy Use?

-No $-\mathrm{Yes}$

$95.00 \%$

$5.00 \%$

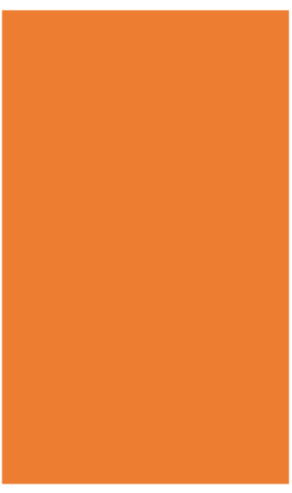

Figure 4.1: Survey Responses to Q1

Q2: Are Facilites Adjusting or Switching Off

Energy Equipment When Not in Use?

- No $\square$ Yes

$95.00 \%$

$5.00 \%$

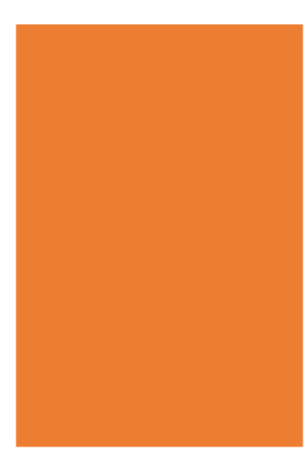

Figure 4.2:Survey Responses to Q2 


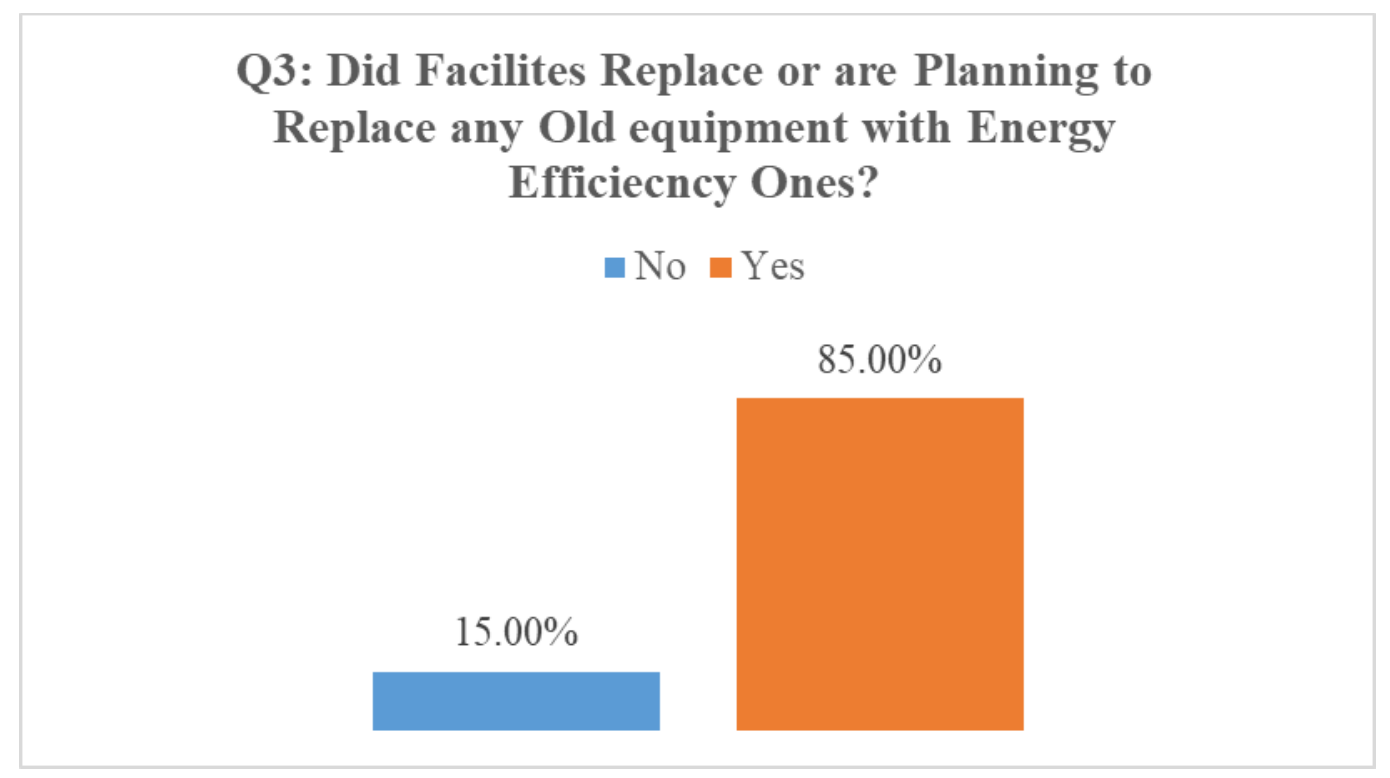

Figure 4.3:Survey Responses to Q3

First three question were aimed to understand if facilities were keeping a tab on their energy usage by keep track of their energy usage, or not operating equipment when not required or by replacing the old energy consuming equipment with new ones, whereas fourth question aims to understand the facilities willingness to get and energy audit.

In response to question 4, as shown in Figure 4.4, whether a facility is interested in getting an energy audit at their facility, only $15 \%$ of the facilities have responded saying yes, other $85 \%$ of the facilities have said that they are not interested in the getting an energy audit of their facilities. Out of the seventeen facilities which said they are not interested in getting an energy of their facility, 16 of them have said they are conscious of their facilities energy usage and taking actions to switch off or control energy consuming equipment when not needed, fourteen of them have said that they have replaced their old energy consuming equipment with new ones. 


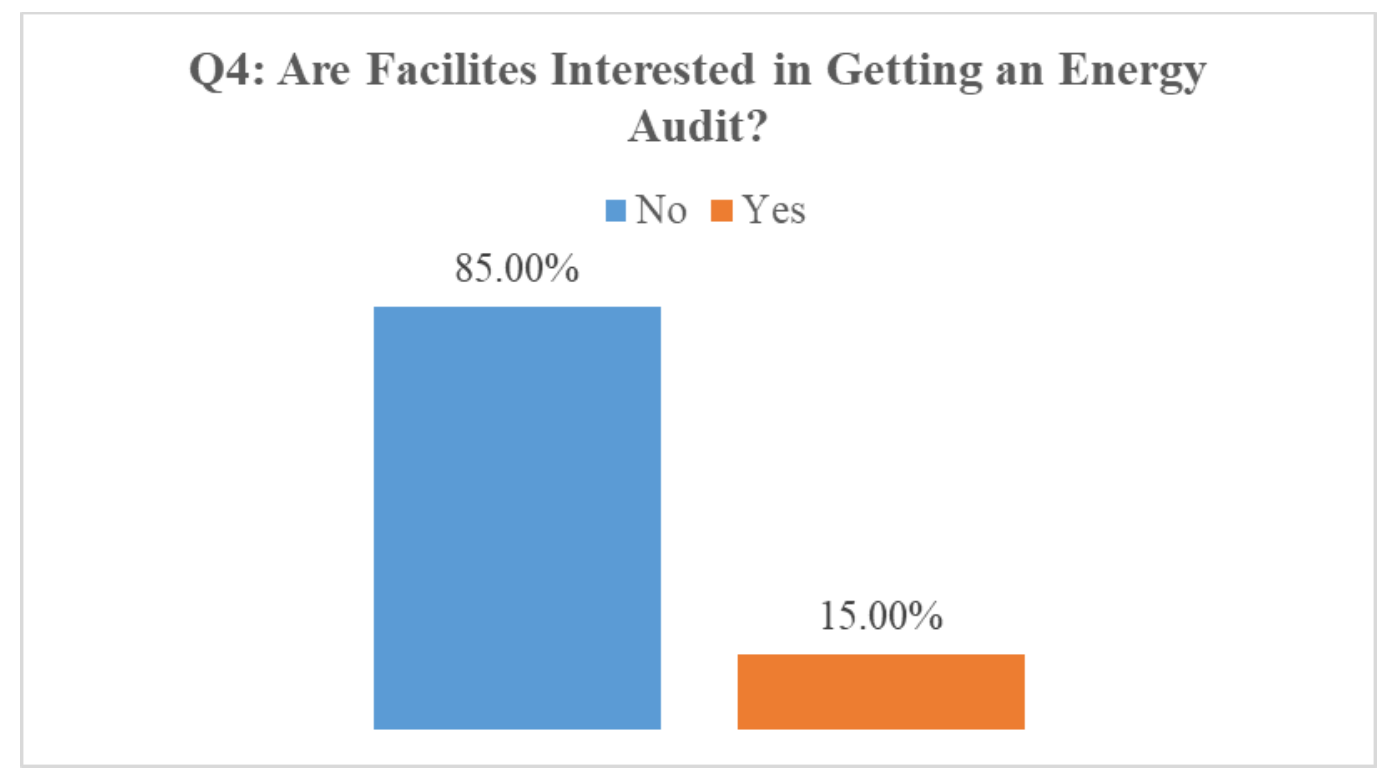

Figure 4.4: Survey Responses to Q4

\subsection{Survey Response Analysis}

After answering the first set of questions, participants were asked to read the attached brochure. Traditional brochure contained the information pertaining to the benefits of energy efficiency and technical and financial resources available to the business to pursue energy efficiency. Virtual brochure contained potential energy conservation opportunities available addressing a specific facility and estimated achievable dollar savings associated with these energy conservation measures. And the virtual brochure also had the information pertaining to the benefits of energy efficiency, and technical and financial resources available to the business to pursue energy efficiency.

It was expected that after reading the brochure, the participants are informed about the potential energy efficiency opportunities they have at their facility and benefits of the energy efficiency based on the type of brochure they have received. Now participants were asked if their response 
to question 4 i.e. whether a facility is interested to an energy audit at their facility, has changed after reading the brochure.

Six participants, i.e. $30 \%$ of the total participants have said that their response to question 4 has changed, meaning initially participants were not interested in getting an energy audit but after reading the brochure they have changed their opinion to get an energy audit at their facility. Three out of eleven virtual respondents i.e. $27 \%$ and, 3 out of 9 traditional participants i.e., $33 \%$ have said that they changed their opinion from not interested in energy audit to getting an energy audit at their facility.

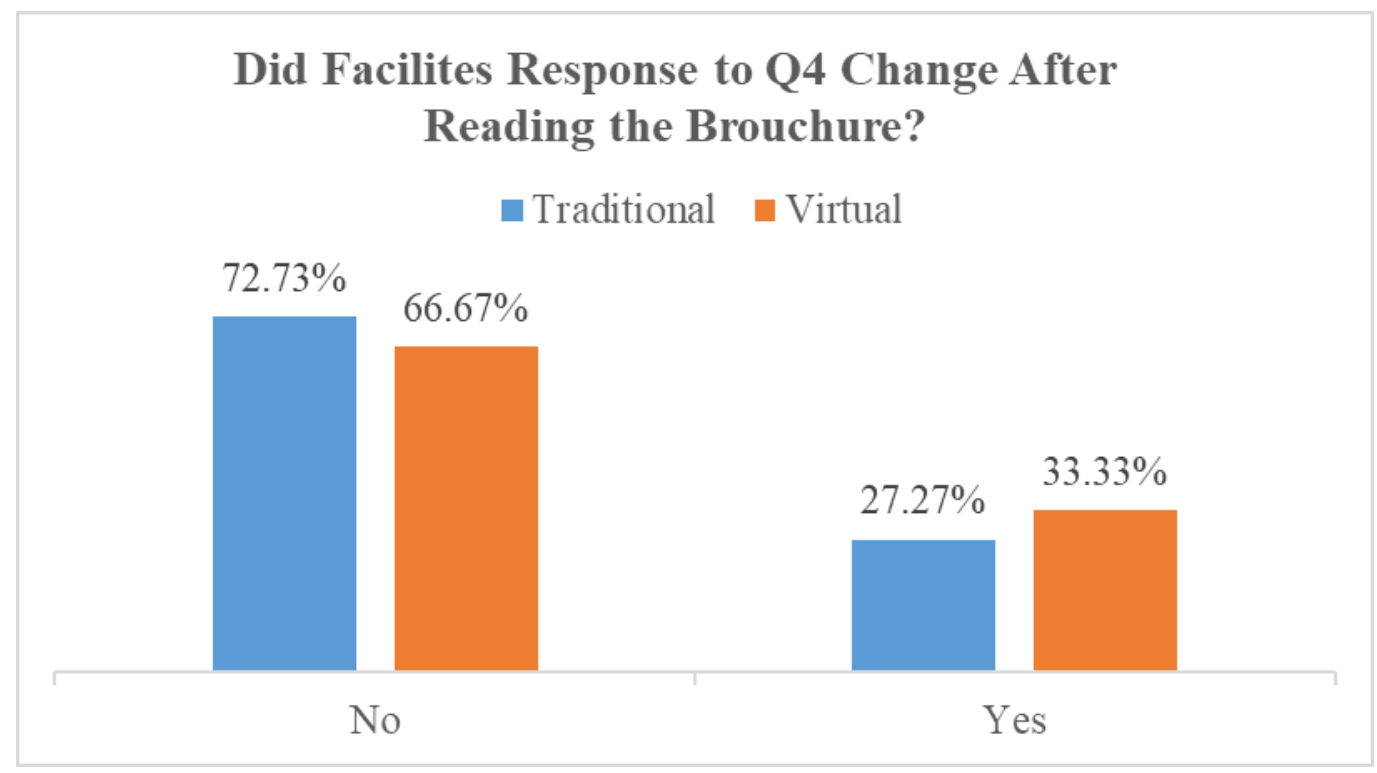

Figure 4.5:Survey Responses After Reading the Brochure.

As we can see from question 3 responses that about $85 \%$ of the facilities have had or planning to have the old energy consuming equipment replaced with energy efficiency equipment. Though it cannot be inferred with certainty from response to question 3 that the facilities replaced their old equipment with energy efficient ones as a result of an energy audit, but this much can be understood that the facility recently thought about their energy usage and took some kind of steps. 
This is possibly one of the reasons why $85 \%$ of the participants have said that they are not interested in the energy audit even before reading the brochure.

Given that the participant has answered no to question 3, i.e., facility has not replaced or not planning to replace the old energy consuming equipment with energy efficient ones, $100 \%$ participants who have received the virtual brochure have changed their responses from not interested in getting an energy audit to getting an energy audit for question 4 to interested in getting an energy audit to getting an energy audit, whereas for $0 \%$ of the participants who received traditional leaflet no change in their response for question 4 was observed. It should be noted that there were only three participants who answered no to question 3 and breakdown of the three participant responses is given in Table 4.1 .

Table 4.1: Survey Reponses of Participants who have Answered No for Q3

\begin{tabular}{|l|c|c|c|}
\hline \multirow{2}{*}{ Survey Type } & \multicolumn{2}{|c|}{ Before Reading the Brochure } & After Reading the Brochure \\
\cline { 2 - 4 } & Q3 & Q4 & Q4 \\
\hline Virtual & No & No & Yes \\
\hline Virtual & No & No & No \\
\hline Traditional & No & No & \\
\hline
\end{tabular}

Due to low response rate, sample was not large enough to make any statistical analysis to draw conclusions. Due to lack of data we cannot say with confidence one way or the other about the objective set out for this study, i.e., whether a virtual audit-based marketing strategy is of any significant difference in comparison to a generic leaflet-based marketing strategy to encourage businesses pursue energy efficiency. Responses to all the questions from all the participants can be found in Appendix C-5. 


\subsection{Discussion and Conclusion}

One of the important contributions of this study is the development of a virtual audit tool. The tool can perform a virtual audit for any facility based on minimum inputs and most of these inputs are publicly available information such as type of business, location of the facility, operating hours and area. Using this information, the virtual audit can be completed within a few minutes. Based on our personal interaction with a few business owners it was observed that the businesses which received the virtual energy marketing brochure were pleasantly surprised to know the cost saving potential at their facilities.

The virtual audit tool presented in this study is simplistic and makes several assumptions. There is a lot of scope to improve the tool.

For e.g., summarized results from the Commercial Businesses Energy Consumption Survey (CBECS) and Lighting Market Characterization (LMC) datasets were used to develop the commercial virtual audit tool, rather than using summarized results, raw data can be used from these datasets to build a more robust tool. Using raw data will provide us more control over the data by selecting data for an energy system or type of equipment or business operation in focus. CBECS and LMC datasets cover the whole of U.S. West Virginia is ranked 49, i.e. second from last in energy efficiency rankings in the U.S. [32]. As West Virginia is ranked poorly in the energy efficiency, summarized values of data points might not be good representation for West Virginia. Using the raw data from CBECS and LMC will enable us to select data for the regions which are like West Virginia in energy efficiency.

Commercial and Industrial virtual energy audit tools have estimated the savings for most common types of energy systems and their associated energy conservation measures. With the available 
data more sophisticated data models can be developed to recommend and estimate customized set of energy conservation measures for various energy systems based on businesses type. Importing map from GPS software such as google maps can be automated.

Outputs from the energy audit tool are not validated in this study, but future studies can focus on validation of results to make the tool more robust. For example, results from energy audits, implementation and savings studies etc. can be used to compare the results from the virtual energy audit tool.

A response rate of $10 \%$ was observed in this study. Response rates for similar surveys in energy efficiency domain were found to more than $50 \%$ [33] [34]. There are several possible reasons for the low response rate. Compared to the previous studies the duration in which this study was completed was short. This studies' duration was one month, in comparison similar studies had durations of at least 3 months [33] [35] [34]. Another possible reason could be that the managers (not owner) of the facility who received the survey were not capable of making independent decisions regarding energy audit. We also learned from the persons working at the facilities that owners or landlords could be interested in saving energy, but the logistics of coordination generally not let these things move fast, making them take back seat in the list of priorities. It is also possible that type of ownership of the place (rented vs owned) may have also attributed to the low response rate as many small commercial businesses rent their facilities.

To avail higher response rate, future studies may consider conducting the study over a longer duration, include e-survey - which can facilitate the back and forth communication with the businesses, develop a structured follow-up process (phone call, email, etc.) 
In conclusion, it was observed that most of the survey respondents were interested in reducing their energy bills and were taking steps to control their energy costs. Many facilities were showed genuine interest in energy efficiency, but most were not in position to make decision regarding an energy audit at their facility. Due to a low response rate, results of survey study regarding comparison of traditional leaflet-based marketing strategy with virtual audit-based marketing strategy were inconclusive. 


\section{References}

[1] BP, “BP: Statistical Review of World Energy,” 2018.

[2] International Energy Agency, "World Energy Outlook," 2018.

[3] D. Jocelyn and C. Megan, "Energy Efficiency State Legislative Update: 2016 and 2017," 2018. [Online]. Available: http://www.ncsl.org/research/energy/energy-efficiency-statelegislative-update-2016-2017.aspx. [Accessed: 10-Jan-2019].

[4] S. Fred, "Energy Independence and Security Act of 2007: A Summary of Major Provisions," 2007.

[5] "Energy Audits | ACEEE." [Online]. Available: https://aceee.org/topics/energy-audits. [Accessed: 11-Jan-2019].

[6] M. Baechler, C. Strecker, and J. Shafer, "A Guide to Energy Audits," 2011.

[7] J. M. Avina and S. P. Rottmayer, "Virtual Audits: The Promise and The Reality," Energy Eng., vol. 113, no. 6, pp. 34-52, Sep. 2016.

[8] E. Hoşgör and P. S. Fischbeck, "Virtual home energy auditing at scale: Predicting residential energy efficiency using publicly available data," Energy Build., vol. 92, pp. 6780, Apr. 2015.

[9] "Energy Performance Indicator Tool | Department of Energy." [Online]. Available: https://www.energy.gov/eere/amo/articles/energy-performance-indicator-tool. [Accessed: 23-Apr-2019].

[10] "Energy Footprint Tool | Department of Energy." [Online]. Available: https://www.energy.gov/eere/amo/downloads/energy-footprint-tool. [Accessed: 23-Apr- 
2019].

[11] "Plant Energy Profiler Excel | Department of Energy." [Online]. Available: https://www.energy.gov/eere/amo/downloads/plant-energy-profiler-excel. [Accessed: 23Apr-2019].

[12] "Welcome to Scout — Scout documentation." [Online]. Available: https://scoutbto.readthedocs.io/en/latest/\#welcome-to-scout. [Accessed: 23-Apr-2019].

[13] Y. Qiu, Y. D. Wang, and J. Wang, "Implied discount rate and payback threshold of energy efficiency investment in the industrial sector," vol. 47, no. 24, pp. 2218-2233, 2015.

[14] S. Muthulingam, C. J. Corbett, S. Benartzi, and F. R. Seaver, "Managerial Biases and Energy Savings: An Empirical Analysis of the Adoption of Process Improvement Recommendations Bohdan Oppenheim,” 2009.

[15] A. B. Jaffe and R. N. Stavins, "The energy paradox and the diffusion of conservation technology,” Resour. Energy Econ., vol. 16, no. 2, pp. 91-122, May 1994.

[16] J. K. Swales, G. Allan, P. G. McGregor, and K. Turner, "The economics of energy efficiency," Encycl. Energy, vol. 2, pp. 79-90, 2009.

[17] P. Linares and X. Labandeira, "Energy Efficiency: Economics and Policy," J. Econ. Surv., vol. 24, no. 3, pp. 573-592, Mar. 2010.

[18] T. D. Gerarden, R. G. Newell, and R. N. Stavins, “Assessing the Energy-Efficiency Gap,” 2015.

[19] H. Allcott and M. Greenstone, "Is There an Energy Efficiency Gap?," J. Econ. Perspect., vol. 26, pp. 3-28, 2012. 
[20] "Use of Energy in the United States - Energy Explained, Your Guide To Understanding Energy - Energy Information Administration.” [Online]. Available: https://www.eia.gov/energyexplained/index.php?page=us_energy_use. [Accessed: 23Mar-2019].

[21] "Commercial Buildings Energy Consumption Survey (CBECS) - Terminology - U.S. Energy Information Administration (EIA)." [Online]. Available: https://www.eia.gov/consumption/commercial/terminology.php. [Accessed: 23-Mar2019].

[22] “CBECS 2012: Energy Usage Summary." [Online]. Available: https://www.eia.gov/consumption/commercial/reports/2012/energyusage/. [Accessed: 23Mar-2019].

[23] N. Buccitelli, C. Elliott, S. Schober, and M. Yamada, "2015 U . S . Lighting Market Characterization," 2015.

[24] “CBECS 2012: Trends in Lighting in Commercial Buildings." [Online]. Available: https://www.eia.gov/consumption/commercial/reports/2012/lighting/?src=< Consumption Commercial Buildings Energy Consumption Survey (CBECS)-b1. [Accessed: 29-Mar2019].

[25] “Top 8 Things You Didn't Know About LEDs | Department of Energy.” [Online]. Available: https://www.energy.gov/articles/top-8-things-you-didn-t-know-about-leds. [Accessed: 01-Apr-2019].

[26] W. Wang, Y. Huang, S. Katipamula, and M. R. Brambley, "Energy Savings and Economics of Advanced Control Strategies for Packaged Air-Conditioning Units with Gas Heat,” 2011. 
[27] “Table C24. Natural gas consumption and expenditure intensities, 2012."

[28] “ENERGY STAR ® Residential Water Heaters: Final Criteria Analysis,” 2008.

[29] "Table E7. Natural gas consumption and conditional energy intensities (Btu) by end use, 2012."

[30] "Table C14. Electricity consumption and expenditure intensities, 2012." [Online]. Available: $\quad$ https://www.eia.gov/consumption/commercial/data/2012/c\&e/cfm/c14.php. [Accessed: 01-Apr-2019].

[31] M. R. Muller and D. J. Kasten, "Industrial Assessment Center Assessment Recommendation Code (ARC)," 2007.

[32] W. Berg et al., "The 2018 State Energy Efficiency Scorecard,” 2018.

[33] M. Zhang, M. Wang, W. Jin, and C. Xia-Bauer, "Managing energy efficiency of buildings in China: A survey of energy performance contracting (EPC) in building sector," Energy Policy, vol. 114, pp. 13-21, Mar. 2018.

[34] T. Virkki-Hatakka, M. Luoranen, and M. Ikävalko, "Differences in perception: How the experts look at energy efficiency (findings from a Finnish survey),” 2013.

[35] X. Liu, D. Niu, C. Bao, S. Suk, and T. Shishime, “A survey study of energy saving activities of industrial companies in Taicang, China," J. Clean. Prod., vol. 26, pp. 79-89, 2012.

[36] “Commercial Buildings Energy Consumption Survey (CBECS) - Building Type Definition - U.S. Energy Information Administration (EIA)." [Online]. Available: https://www.eia.gov/consumption/commercial/building-type-definitions.php. [Accessed: 23-Mar-2019]. 
[37] “2017 Utility Bundled Retail Sales-Commercial (Data from forms EIA-861-schedules 4A \&amp; 4D and EIA-861S).”

[38] "West Virginia Price of Natural Gas Sold to Commercial Consumers (Dollars per Thousand Cubic Feet)." [Online]. Available: https://www.eia.gov/dnav/ng/hist/n3020wv3m.htm. [Accessed: 30-Mar-2019].

[39] M. C. Baechler, T. L. Gilbride, P. C. Cole, M. G. Hefty, and K. Ruiz, "Guide to Determining Climate Regions by County PREPARED BY Pacific Northwest National Laboratory," 2015. 


\section{Appendix}

\section{Appendix A: $\quad$ Commercial Virtual Energy Audit Tool}

\section{Appendix A-1 Commercial Business Definition}

Commercial Building Type Definitions [36]

\begin{tabular}{|c|c|c|}
\hline Building type & Definition & $\begin{array}{l}\text { Includes these sub-categories } \\
\text { from the CBECS questionnaire }\end{array}$ \\
\hline Education & $\begin{array}{l}\text { Buildings used for academic or technical } \\
\text { classroom instruction, such as elementary, } \\
\text { middle, or high schools, and classroom } \\
\text { buildings on college or university } \\
\text { campuses. Buildings on education } \\
\text { campuses for which the main use is not } \\
\text { classroom are included in the category } \\
\text { relating to their use. For example, } \\
\text { administration buildings are part of } \\
\text { "Office," dormitories are "Lodging," and } \\
\text { libraries are "Public Assembly." }\end{array}$ & $\begin{array}{l}\text { - } \text { elementary or middle } \\
\text { school } \\
\text { - } \text { high school } \\
\text { - college or university } \\
\text { - preschool or daycare } \\
\text { - } \text { adult education } \\
\text { - career or vocational } \\
\text { - } \text { training } \\
\text { religious education }\end{array}$ \\
\hline Food Sales & $\begin{array}{l}\text { Buildings used for retail or wholesale of } \\
\text { food. }\end{array}$ & $\begin{array}{l}\text { - grocery store or food } \\
\text { market } \\
\text { - gas station with a } \\
\text { convenience store } \\
\text { - convenience store }\end{array}$ \\
\hline
\end{tabular}




\begin{tabular}{|c|c|c|}
\hline Building type & Definition & $\begin{array}{l}\text { Includes these sub-categories } \\
\text { from the CBECS questionnaire }\end{array}$ \\
\hline Food Service & $\begin{array}{l}\text { Buildings used for preparation and sale of } \\
\text { food and beverages for consumption. }\end{array}$ & $\begin{array}{l}\text { - } \text { fast food } \\
\text { - } \text { restaurant or cafeteria } \\
\text { - } \text { bar } \\
\text { catering service or } \\
\text { reception hall } \\
\text { - coffee, bagel, or } \\
\text { doughnut shop } \\
\text { - ice cream or frozen yogurt } \\
\text { shop }\end{array}$ \\
\hline $\begin{array}{l}\text { Health Care } \\
\text { (Inpatient) }\end{array}$ & $\begin{array}{l}\text { Buildings used as diagnostic and } \\
\text { treatment facilities for inpatient care. }\end{array}$ & $\begin{array}{l}\text { - hospital } \\
\text { - inpatient rehabilitation }\end{array}$ \\
\hline $\begin{array}{l}\text { Health Care } \\
\text { (Outpatient) }\end{array}$ & $\begin{array}{l}\text { Buildings used as diagnostic and } \\
\text { treatment facilities for outpatient care. } \\
\text { Medical offices are included here if they } \\
\text { use any type of diagnostic medical } \\
\text { equipment (if they do not, they are } \\
\text { categorized as an office building). }\end{array}$ & $\begin{array}{l}\text { medical office (see } \\
\text { previous column) } \\
\text { clinic or other } \\
\text { outpatient health care } \\
\text { outpatient } \\
\text { rehabilitation } \\
\text { veterinarian }\end{array}$ \\
\hline Lodging & $\begin{array}{l}\text { Buildings used to offer multiple } \\
\text { accommodations for short-term or long- } \\
\text { term residents, including skilled nursing } \\
\text { and other residential care buildings. }\end{array}$ & $\begin{array}{l}\text { - } \text { motel or inn } \\
\text { - } \text { hotel dormitory, fraternity, } \\
\text { or sorority } \\
\text { - } \text { retirement home } \\
\text { - nursing home, } \\
\text { assisted living, or } \\
\text { other residential care } \\
\text { - convent or monastery } \\
\text { - shelter, orphanage, or } \\
\text { children's home } \\
\text { - halfway house }\end{array}$ \\
\hline
\end{tabular}




\begin{tabular}{|c|c|c|}
\hline Building type & Definition & $\begin{array}{l}\text { Includes these sub-categories } \\
\text { from the CBECS questionnaire }\end{array}$ \\
\hline $\begin{array}{l}\text { Mercantile } \\
\text { (Retail Other } \\
\text { Than Mall) }\end{array}$ & $\begin{array}{l}\text { Buildings used for the sale and display of } \\
\text { goods other than food. }\end{array}$ & $\begin{array}{ll}\text { - } & \text { retail store } \\
\text { - } & \text { beer, wine, or liquor } \\
& \text { store } \\
\text { - } & \text { rental center } \\
\text { - } & \text { dealership } \\
& \text { showroom or } \\
& \text { vehicles or boats } \\
\text { - } & \text { studio/gallery } \\
\end{array}$ \\
\hline $\begin{array}{c}\text { Mercantile } \\
\text { (Enclosed and } \\
\text { Strip Malls) }\end{array}$ & $\begin{array}{l}\text { Shopping malls comprised of multiple } \\
\text { connected establishments. }\end{array}$ & $\begin{array}{l}\text { - } \quad \text { enclosed mall } \\
\text { - } \quad \text { strip shopping center }\end{array}$ \\
\hline Office & $\begin{array}{l}\text { Buildings used for general office space, } \\
\text { professional office, or administrative } \\
\text { offices. Medical offices are included here } \\
\text { if they do not use any type of diagnostic } \\
\text { medical equipment (if they do, they are } \\
\text { categorized as an outpatient health care } \\
\text { building). }\end{array}$ & $\begin{array}{ll}\text { - } & \text { administrative or } \\
& \text { professional office } \\
\text { - } & \text { government office } \\
\text { - } & \text { mixed-use office } \\
\text { - } & \text { bank or other financial } \\
\text { institution } \\
\text { - } \text { medical office (see } \\
\text { previous column) } \\
\text { - } \text { sales office } \\
\text { contractor's office } \\
\text { (e.g. construction, } \\
\text { plumbing, HVAC) } \\
\text { non-profit or social } \\
\text { services city hall or city center } \\
\text { - religious office } \\
\text { call center }\end{array}$ \\
\hline
\end{tabular}




\begin{tabular}{|c|c|c|}
\hline Building type & Definition & $\begin{array}{l}\text { Includes these sub-categories } \\
\text { from the CBECS questionnaire }\end{array}$ \\
\hline $\begin{array}{l}\text { Public } \\
\text { Assembly }\end{array}$ & $\begin{array}{l}\text { Buildings in which people gather for } \\
\text { social or recreational activities, whether in } \\
\text { private or non-private meeting halls. }\end{array}$ & 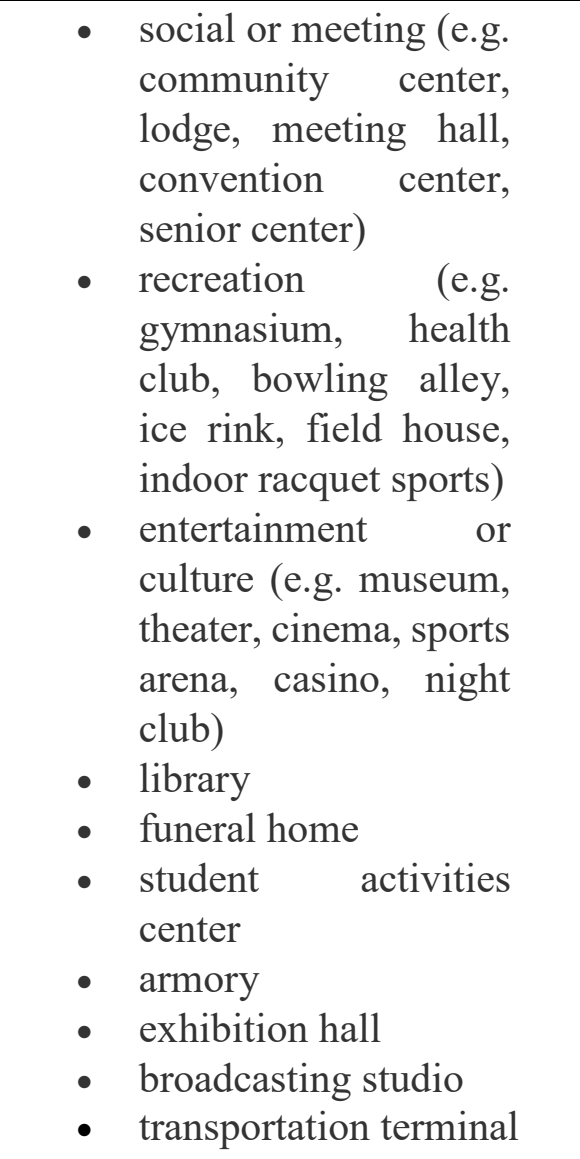 \\
\hline $\begin{array}{l}\text { Public Order } \\
\text { and Safety }\end{array}$ & $\begin{array}{l}\text { Buildings used for the preservation of law } \\
\text { and order or public safety. }\end{array}$ & 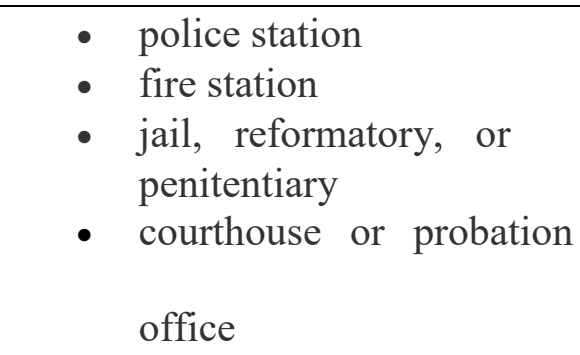 \\
\hline $\begin{array}{l}\text { Religious } \\
\text { Worship }\end{array}$ & $\begin{array}{l}\text { Buildings in which people gather for } \\
\text { religious activities, (such as chapels, } \\
\text { churches, mosques, synagogues, and } \\
\text { temples). }\end{array}$ & $\begin{array}{l}\text { - No subcategories } \\
\text { collected }\end{array}$ \\
\hline
\end{tabular}




\begin{tabular}{|c|c|c|}
\hline Building type & Definition & $\begin{array}{l}\text { Includes these sub-categories } \\
\text { from the CBECS questionnaire }\end{array}$ \\
\hline Service & $\begin{array}{l}\text { Buildings in which some type of service is } \\
\text { provided, other than food service or retail } \\
\text { sales of goods }\end{array}$ & 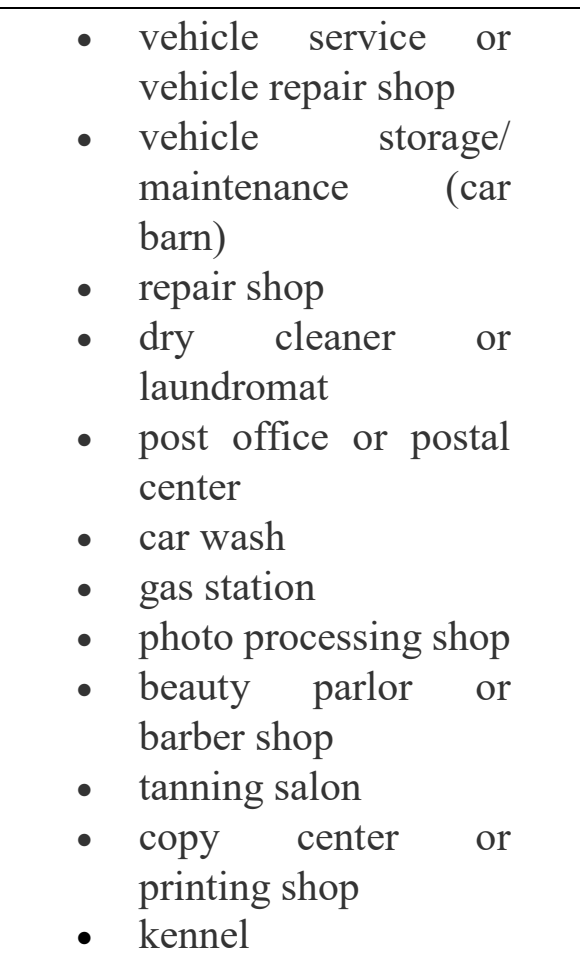 \\
\hline $\begin{array}{l}\text { Warehouse } \\
\text { and Storage }\end{array}$ & $\begin{array}{l}\text { Buildings used to store goods, } \\
\text { manufactured products, merchandise, raw } \\
\text { materials, or personal belongings (such as } \\
\text { self-storage). }\end{array}$ & $\begin{array}{ll}\text { - } & \text { refrigerated } \\
& \text { warehouse } \\
\text { - } & \text { non-refrigerated } \\
\text { warehouse } \\
\text { distribution or shipping } \\
\text { center }\end{array}$ \\
\hline Other & $\begin{array}{l}\text { Buildings that are industrial or agricultural } \\
\text { with some retail space; buildings having } \\
\text { several different commercial activities } \\
\text { that, together, comprise } 50 \text { percent or } \\
\text { more of the floorspace, but whose largest } \\
\text { single activity is agricultural, industrial/ }\end{array}$ & $\begin{array}{l}\text { - } \text { airplane hangar } \\
\text { - } \text { crematorium } \\
\text { - } \text { laboratory } \\
\text { - } \text { agricultural with some } \\
\text { retail space } \\
\text { - manufacturing or } \\
\text { industrial with some } \\
\text { retail space } \\
\text { - data center or server farm }\end{array}$ \\
\hline
\end{tabular}




\begin{tabular}{|c|c|c|}
\hline Building type & Definition & $\begin{array}{l}\text { Includes these sub-categories } \\
\text { from the CBECS questionnaire }\end{array}$ \\
\hline & $\begin{array}{l}\text { manufacturing, or residential; and all } \\
\text { other miscellaneous buildings that do not } \\
\text { fit into any other category. }\end{array}$ & \\
\hline Vacant & $\begin{array}{l}\text { Buildings in which more floorspace was } \\
\text { vacant than was used for any single } \\
\text { commercial activity at the time of } \\
\text { interview. Therefore, a vacant building } \\
\text { may have some occupied floorspace. }\end{array}$ & $\begin{array}{l}\text { - No subcategories } \\
\text { collected, but a question } \\
\text { was asked to determine } \\
\text { whether the building was } \\
\text { completely vacant. }\end{array}$ \\
\hline Education & $\begin{array}{l}\text { Buildings used for academic or technical } \\
\text { classroom instruction, such as elementary, } \\
\text { middle, or high schools, and classroom } \\
\text { buildings on college or university } \\
\text { campuses. Buildings on education } \\
\text { campuses for which the main use is not } \\
\text { classroom are included in the category } \\
\text { relating to their use. For example, } \\
\text { administration buildings are part of } \\
\text { "Office," dormitories are "Lodging," and } \\
\text { libraries are "Public Assembly." }\end{array}$ & $\begin{array}{l}\text { - } \text { elementary or middle } \\
\text { - } \text { hchool } \\
\text { - } \quad \text { college or university } \\
\text { - } \quad \text { preschool or daycare } \\
\text { - } \text { adult education } \\
\text { - career or vocational } \\
\text { - } \text { training } \\
\text { - religious education }\end{array}$ \\
\hline Food Sales & $\begin{array}{l}\text { Buildings used for retail or wholesale of } \\
\text { food. }\end{array}$ & $\begin{array}{l}\text { - } \text { grocery store or food } \\
\text { market } \\
\text { gas station with a } \\
\text { convenience store }\end{array}$ \\
\hline
\end{tabular}




\begin{tabular}{|l|c|c|}
\hline Building type & Definition & $\begin{array}{c}\text { Includes these sub-categories } \\
\text { from the CBECS questionnaire }\end{array}$ \\
\hline & $\bullet$ convenience store \\
\hline $\begin{array}{c}\text { Note: These subcategories are not exhaustive lists of the types of buildings included in } \\
\text { each category. For every general category, there are some "other" types of buildings that } \\
\text { did not fit into any of these given subcategories. }\end{array}$ \\
\hline
\end{tabular}




\section{Appendix A-2 Utility Bundled Retail Sales- Commercial}

Utility Bundled Retail Sales- Commercial [37]

\begin{tabular}{|c|c|c|c|c|c|c|}
\hline Entity & State & Ownership & $\begin{array}{l}\text { Customers } \\
\text { (Count) }\end{array}$ & $\begin{array}{c}\text { Sales } \\
\text { (Megawatt hours) }\end{array}$ & $\begin{array}{c}\text { Revenues } \\
\text { (Thousands of Dollars) }\end{array}$ & $\begin{array}{c}\text { Average Price } \\
\text { (cents/kWh) }\end{array}$ \\
\hline $\begin{array}{l}\text { Appalachian Power } \\
\text { Co }\end{array}$ & WV & $\begin{array}{l}\text { Investor } \\
\text { Owned }\end{array}$ & 66,352 & $3,380,620$ & $313,447.00$ & 9.27 \\
\hline $\begin{array}{l}\text { Black Diamond } \\
\text { Power Co }\end{array}$ & WV & $\begin{array}{l}\text { Investor } \\
\text { Owned }\end{array}$ & 481 & 14,918 & $1,770.40$ & 11.87 \\
\hline $\begin{array}{l}\text { Craig-Botetourt } \\
\text { Electric Coop }\end{array}$ & WV & Cooperative & 52 & 284 & 49.1 & 17.29 \\
\hline $\begin{array}{l}\text { Monongahela } \\
\text { Power Co }\end{array}$ & WV & $\begin{array}{c}\text { Investor } \\
\text { Owned }\end{array}$ & 51,346 & $2,821,062$ & $276,971.90$ & 9.82 \\
\hline $\begin{array}{l}\text { The Potomac } \\
\text { Edison Co }\end{array}$ & WV & $\begin{array}{l}\text { Investor } \\
\text { Owned }\end{array}$ & 17,967 & 828,550 & $82,564.90$ & 9.96 \\
\hline Wheeling Power Co & WV & $\begin{array}{l}\text { Investor } \\
\text { Owned }\end{array}$ & 6,242 & 448,726 & $41,464.00$ & 9.24 \\
\hline Average & - & - & - & - & - & 11.24 \\
\hline
\end{tabular}

Appendix A-3 West Virginia Price of Natural Gas Sold to Commercial Consumers (Dollars per Thousand Cubic Feet)

West Virginia Price of Natural Gas Sold to Commercial Consumers (Dollars per Thousand Cubic Feet) [38]

\begin{tabular}{|c|c|c|c|c|c|c|c|c|c|c|c|c|c|}
\hline \multicolumn{14}{|c|}{ West Virginia Price of Natural Gas Sold to Commercial Consumers (Dollars per Thousand Cubic Feet) } \\
\hline Year & Jan & Feb & Mar & Apr & May & Jun & Jul & Aug & Sep & Oct & Nov & Dec & Average \\
\hline 2017 & 6.97 & 7.02 & 7.09 & 7.71 & 8.28 & 9.48 & 9.54 & 9.37 & 8.93 & 8.56 & 7.86 & 7.66 & 8.21 \\
\hline
\end{tabular}




\section{Appendix A-4 Climate Regions by County}

Climate Regions by County [39]

\begin{tabular}{|l|l|l|}
\hline State & County & Climate Zone \\
\hline WV & Barbour & Cold \\
\hline WV & Berkeley & Mixed-Humid \\
\hline WV & Boone & Mixed-Humid \\
\hline WV & Braxton & Mixed-Humid \\
\hline WV & Brooke & Cold \\
\hline WV & Cabell & Mixed-Humid \\
\hline WV & Calhoun & Mixed-Humid \\
\hline WV & Clay & Mixed-Humid \\
\hline WV & Doddridge & Cold \\
\hline WV & Fayette & Cold \\
\hline WV & Gilmer & Mixed-Humid \\
\hline WV & Grant & Cold \\
\hline WV & Greenbrier & Cold \\
\hline WV & Hampshire & Cold \\
\hline WV & Hancock & Cold \\
\hline WV & Hardy & Cold \\
\hline WV & Harrison & Cold \\
\hline WV & Jackson & Mixed-Humid \\
\hline WV & Jefferson & Mixed-Humid \\
\hline WV & Kanawha & Mixed-Humid \\
\hline WV & Lewis & Cold \\
\hline WV & Lincoln & Mixed-Humid \\
\hline WV & Logan & Mixed-Humid \\
\hline WV & Marion & Cold \\
\hline WV & Marshall & Cold \\
\hline WV & Mason & Mixed-Humid \\
\hline WV & McDowell & Mixed-Humid \\
\hline WV & Mercer & Mixed-Humid \\
\hline & & \\
\hline
\end{tabular}

\begin{tabular}{|l|l|l|}
\hline State & County & Climate Zone \\
\hline WV & Mineral & Cold \\
\hline WV & Mingo & Mixed-Humid \\
\hline WV & Monongalia & Cold \\
\hline WV & Monroe & Mixed-Humid \\
\hline WV & Morgan & Mixed-Humid \\
\hline WV & Nicholas & Cold \\
\hline WV & Ohio & Cold \\
\hline WV & Pendleton & Cold \\
\hline WV & Pleasants & Mixed-Humid \\
\hline WV & Pocahontas & Cold \\
\hline WV & Preston & Cold \\
\hline WV & Putnam & Mixed-Humid \\
\hline WV & Raleigh & Cold \\
\hline WV & Randolph & Cold \\
\hline WV & Ritchie & Mixed-Humid \\
\hline WV & Roane & Mixed-Humid \\
\hline WV & Summers & Cold \\
\hline WV & Taylor & Cold \\
\hline WV & Tucker & Cold \\
\hline WV & Tyler & Mixed-Humid \\
\hline WV & Upshur & Cold \\
\hline WV & Wayne & Mixed-Humid \\
\hline WV & Webster & Cold \\
\hline WV & Wetzel & Cold \\
\hline WV & Wirt & Mixed-Humid \\
\hline WV & Wood & Mixed-Humid \\
\hline WV & Wyoming & Mixed-Humid \\
\hline & & \\
\hline
\end{tabular}


Appendix A-5 Sample Size by NAICS Code

Sample Size by NAICS Code

\begin{tabular}{|l|c|}
\hline $\begin{array}{l}\text { 3-digit NAICS } \\
\text { Code }\end{array}$ & $\begin{array}{l}\text { Sample size of } \\
\text { ECM }\end{array}$ \\
\hline 111 & 22 \\
\hline 112 & 66 \\
\hline 115 & 62 \\
\hline 211 & 19 \\
\hline 212 & 136 \\
\hline 213 & 20 \\
\hline 221 & 659 \\
\hline 236 & 11 \\
\hline 237 & 3 \\
\hline 238 & 58 \\
\hline 311 & 7,040 \\
\hline 312 & 1,287 \\
\hline 313 & 697 \\
\hline 314 & 412 \\
\hline 315 & 299 \\
\hline 316 & 40 \\
\hline 321 & 2,456 \\
\hline 322 & 2,550 \\
\hline 323 & 1,583 \\
\hline 324 & 626 \\
\hline 325 & 3,970 \\
\hline 326 & 6,136 \\
\hline 327 & 1,903 \\
\hline 331 & 3,755 \\
\hline 332 & 7,606 \\
\hline 333 & 4,591 \\
\hline 334 & 2,002 \\
\hline 335 & 1,471 \\
\hline 336 & 4,511 \\
\hline & \\
\hline
\end{tabular}

\begin{tabular}{|l|c|}
\hline $\begin{array}{l}\text { 3-digit NAICS } \\
\text { Code }\end{array}$ & $\begin{array}{l}\text { Sample size of } \\
\text { ECM }\end{array}$ \\
\hline 337 & 1,382 \\
\hline 339 & 1,731 \\
\hline 423 & 175 \\
\hline 424 & 123 \\
\hline 425 & 6 \\
\hline 445 & 19 \\
\hline 453 & 27 \\
\hline 485 & 8 \\
\hline 486 & 4 \\
\hline 488 & 38 \\
\hline 493 & 26 \\
\hline 511 & 259 \\
\hline 519 & 4 \\
\hline 541 & 92 \\
\hline 561 & 37 \\
\hline 562 & 32 \\
\hline 611 & 58 \\
\hline 621 & 10 \\
\hline 622 & 43 \\
\hline 712 & 54 \\
\hline 713 & 13 \\
\hline 721 & 16 \\
\hline 722 & 7 \\
\hline 811 & 63 \\
\hline 812 & 52 \\
\hline 924 & 3 \\
\hline Grand Total & $\mathbf{5 8 , 2 7 3}$ \\
\hline & \\
\hline
\end{tabular}


Appendix A-6 Actual and Estimated Annual Energy Consumption Values for Various Commercial Facilities

Actual and Estimated Annual Energy Consumption Values for Various Commercial Facilities

\begin{tabular}{|c|c|c|c|c|c|c|c|}
\hline Facility & Area & $\begin{array}{c}\text { Operating } \\
\text { Hours }\end{array}$ & $\begin{array}{c}\text { Zip } \\
\text { Code }\end{array}$ & $\begin{array}{c}\text { Actual } \\
\text { Electricity } \\
\text { Usage }\end{array}$ & $\begin{array}{c}\text { Actual } \\
\text { NG } \\
\text { Usage }\end{array}$ & $\begin{array}{c}\text { Estimated } \\
\text { Electricity } \\
\text { Usage }\end{array}$ & $\begin{array}{c}\text { Estimate } \\
\text { NG } \\
\text { Usage }\end{array}$ \\
\hline 1 & 2,500 & 1,820 & 26505 & 11,266 & 107 & 38,000 & 112 \\
\hline 2 & 4,600 & 2,444 & 26505 & 51,380 & 161 & 69,920 & 206 \\
\hline 3 & 2,500 & 2,340 & 26505 & 17,395 & 122 & 38,000 & 112 \\
\hline 4 & 1,200 & 2,288 & 26505 & 3,426 & 41 & 18,240 & 54 \\
\hline 5 & 36,506 & 2,812 & 25703 & 377,286 & 403 & 941,885 & 1,239 \\
\hline 6 & 7,839 & 2,611 & 25701 & 96,060 & N/A & 119,153 & 266 \\
\hline 7 & 1,700 & 3,213 & 26505 & 55,187 & 444 & 76,330 & 76 \\
\hline 8 & 1,350 & 3,570 & 26260 & 16,889 & 224 & 60,615 & 60 \\
\hline 9 & 18,000 & 8,760 & 26505 & $1,186,839$ & 2,739 & 808,200 & 806 \\
\hline 10 & 3,365 & 4,498 & 26845 & 146,011 & N/A & 151,089 & 151 \\
\hline 11 & 14,500 & 3,276 & 26836 & 199,360 & 473 & 651,050 & 649 \\
\hline 12 & 14,000 & 4,550 & 26836 & 233,930 & 258 & 20,300 & 627 \\
\hline 13 & 59,945 & 8,760 & 26757 & 529,561 & 15,938 & 869,203 & 2,685 \\
\hline 14 & 4,500 & 2,550 & 26508 & 43,755 & 72 & 68,400 & 202 \\
\hline 15 & 6,842 & 4,380 & 26241 & 75,435 & 217 & 176,521 & 306 \\
\hline 16 & 9,539 & 2,499 & 26241 & 197,571 & 21,254 & 151,670 & 427 \\
\hline 17 & 5,353 & 4,849 & 26836 & 301,440 & 1,178 & 240,330 & 240 \\
\hline 18 & 3,332 & 4,420 & 26201 & 215,474 & 49 & 50,646 & 149 \\
\hline 19 & 45,000 & 2,964 & 26201 & 170,496 & 136 & 29,700 & 2,016 \\
\hline 20 & 4,500 & 2,808 & 26505 & 27,562 & 58 & 29,700 & 202 \\
\hline
\end{tabular}


Appendix A-7 Actual and Estimated Annual Energy Cost Savings for Various Energy Systems

Actual and Estimated Annual Energy Cost Savings for Various Energy Systems

\begin{tabular}{|c|c|c|c|c|c|c|}
\hline Facility & $\begin{array}{c}\text { Actual NG } \\
\text { Usage }\end{array}$ & $\begin{array}{c}\text { Actual } \\
\text { Lighting } \\
\text { Cost Saving }\end{array}$ & $\begin{array}{c}\text { Actual } \\
\text { HVAC Cost } \\
\text { Saving }\end{array}$ & $\begin{array}{c}\text { Estimate } \\
\text { Lighting } \\
\text { Cost } \\
\text { Saving }\end{array}$ & $\begin{array}{c}\text { Estimate } \\
\text { HVAC Cost } \\
\text { Saving }\end{array}$ & $\begin{array}{c}\text { Estimate } \\
\text { Hot } \\
\text { Water } \\
\text { Cost } \\
\text { Saving }\end{array}$ \\
\hline 1 & 107 & 223 & N/A & 232 & 437 & 16 \\
\hline 2 & 161 & 2,048 & 927 & 571 & 804 & 29 \\
\hline 3 & 122 & 528 & 768 & 297 & 437 & 16 \\
\hline 4 & 41 & 100 & 376 & 140 & 210 & 8 \\
\hline 5 & 403 & 12,907 & 4,781 & 2,950 & 20,915 & 2,175 \\
\hline 6 & $\mathrm{~N} / \mathrm{A}$ & 3,002 & 1,919 & 1,040 & 1,418 & 49 \\
\hline 7 & 444 & 1,219 & 1,129 & 238 & 297 & 168 \\
\hline 8 & 224 & 485 & 432 & 210 & 236 & 133 \\
\hline 9 & 2,739 & 26,873 & 22,780 & 6,873 & 3,146 & 1,774 \\
\hline 10 & $\mathrm{~N} / \mathrm{A}$ & 2,130 & 3,600 & 660 & 588 & 332 \\
\hline 11 & 473 & 8,203 & 979 & 2,071 & 2,534 & 1,429 \\
\hline 12 & 258 & 3,089 & 7,587 & 2,044 & 2,447 & 74 \\
\hline 13 & 15,938 & 8,152 & 7,229 & 16,846 & 10,478 & 316 \\
\hline 14 & 72 & 1,982 & 1,554 & 583 & 787 & 28 \\
\hline 15 & 217 & 1,060 & 812 & 846 & 1,196 & 408 \\
\hline 16 & 21,254 & 6,472 & 6,713 & 503 & 1,667 & 115 \\
\hline 17 & 1,178 & 3,586 & 10,760 & 1,131 & 936 & 527 \\
\hline 18 & 49 & 844 & 778 & 748 & 582 & 21 \\
\hline 19 & 136 & 2,440 & N/A & 386 & 7,866 & 328 \\
\hline 20 & 58 & 1,099 & 355 & 37 & 787 & 33 \\
\hline
\end{tabular}




\section{Appendix B: Industrial Virtual Energy Audit Tool}

\section{Appendix B-1 IAC Database Assessment Data Points Definition}

\section{IAC Database Assessment Data Points Definition}

\begin{tabular}{|c|c|}
\hline \multicolumn{2}{|r|}{ ASSESSMENT TERMS } \\
\hline ID & Assessment ID \\
\hline CENTER & IAC Center Code \\
\hline FY & Fiscal Year \\
\hline SIC & SIC industrial classification code \\
\hline NAICS & NAICS industrial classification code \\
\hline STATE & US State abbreviation \\
\hline SALES & Total yearly sales \\
\hline EMPLOYEES & Total site employees \\
\hline PLANT_AREA & Total plant square footage \\
\hline PRODUCTS & Types of products \\
\hline PRODUNITS & Production level units \\
\hline PRODLEVEL & Total yearly production \\
\hline PRODHOURS & Total yearly hours of operation \\
\hline NUMARS & Total number of recommendations \\
\hline EC_plant_cost & Total yearly electricity consumption costs $(\$)$ \\
\hline EC_plant_usage & Total yearly electricity consumption $(\mathrm{kWh})$ \\
\hline ED_plant_cost & Total yearly electricity demand charges (\$) \\
\hline ED_plant_usage & Total yearly electricity demand (kW-month-year) \\
\hline EF_plant_cost & Total yearly electricity fees \\
\hline E2_plant_cost & Total yearly natrual gas consumption costs (\$) \\
\hline E2_plant_usage & Total yearly natural gas consumption (MMBtu) \\
\hline E3_plant_cost & Total yearly LPG consumption costs $(\$)$ \\
\hline E3_plant_usage & Total yearly LPG consumption (MMBtu) \\
\hline E4_plant_cost & Total yearly \#1 Fuel Oil consumption costs (\$) \\
\hline E4_plant_usage & Total yearly\#1 Fuel Oil consumption (MMBtu) \\
\hline E5_plant_cost & Total yearly \#2 Fuel Oil consumption costs $(\$)$ \\
\hline E5_plant_usage & Total yearly \#2 Fuel Oil consumption (MMBtu) \\
\hline E6_plant_cost & Total yearly \#4 Fuel Oil consumption costs $(\$)$ \\
\hline E6_plant_usage & Total yearly \#4 Fuel Oil consumption (MMBtu) \\
\hline E7_plant_cost & Total yearly \#6 Fuel Oil consumption costs $(\$)$ \\
\hline E7_plant_usage & Total yearly \#6 Fuel Oil consumption (MMBtu) \\
\hline
\end{tabular}




\begin{tabular}{|c|c|}
\hline \multicolumn{2}{|r|}{ ASSESSMENT TERMS } \\
\hline E8_plant_cost & Total yearly Coal consumption costs $(\$)$ \\
\hline E8_plant_usage & Total yearly Coal consumption (MMBtu) \\
\hline E9_plant_cost & Total yearly Wood consumption costs $(\$)$ \\
\hline E9_plant_usage & Total yearly Wood consumption (MMBtu) \\
\hline E10_plant_cost & Total yearly Paper consumption costs $(\$)$ \\
\hline E10_plant_usage & Total yearly Paper consumption (MMBtu) \\
\hline E11_plant_cost & Total yearly Other Gas consumption costs $(\$)$ \\
\hline E11_plant_usage & Total yearly Other Gas consumption (MMBtu) \\
\hline E12_plant_cost & Total yearly Other Energy consumption costs $(\$)$ \\
\hline E12_plant_usage & Total yearly Other Energy consumption (MMBtu) \\
\hline W0_plant_cost & Total yearly Water consumption costs $(\$)$ \\
\hline W0_plant_usage & Total yearly Water consumption (Tgal) \\
\hline W1_plant_cost & Total yearly Water disposal costs $(\$)$ \\
\hline W1_plant_usage & Total yearly Water disposal (gal) \\
\hline W2_plant_cost & Total yearly Other Liquid (non-haz) disposal costs (\$) \\
\hline W2_plant_usage & Total yearly Other Liquid (non-haz) disposal (gal) \\
\hline W3_plant_cost & Total yearly Other Liquid (haz) disposal costs (\$) \\
\hline W3_plant_usage & Total yearly Other Liquid (haz) disposal (gal) \\
\hline W4_plant_cost & Total yearly Other Solid (non-haz) disposal costs (\$) \\
\hline W4_plant_usage & Total yearly Other Solid (non-haz) disposal (lbs) \\
\hline W5_plant_cost & Total yearly Other Solid (haz) disposal costs (\$) \\
\hline W5_plant_usage & Total yearly Other Solid (haz) disposal (lbs) \\
\hline W6_plant_cost & Total yearly Gaseous Waste disposal costs $(\$)$ \\
\hline W6_plant_usage & Total yearly Gaseous Waste disposal (lbs) \\
\hline
\end{tabular}


Appendix B-2 IAC Database Recommendation Data Points Definition

\section{IAC Database Recommendation Data Points Definition}

\begin{tabular}{|c|c|}
\hline \multicolumn{2}{|r|}{ RECC Terms } \\
\hline SUPERID & Assessment ID + Recommendation Number \\
\hline ID & Assessment ID \\
\hline AR_NUMBER & Recommendation Number \\
\hline APPCODE & Application Code \\
\hline ARC2 & IAC Assessment Recommendation Code \\
\hline IMPSTATUS & Implementation Status ( $\mathrm{I}=$ implemented, $\mathrm{N}=$ Not Implement $)$ \\
\hline IMPCOST & Total implementation cost \\
\hline PSOURCCODE & Primary resource identification code \\
\hline PCONSERVED & Units conserved \\
\hline PSOURCONSV & Source units conserved \\
\hline PSAVED & Cost savings \\
\hline SSOURCCODE & Secondary resource identification code \\
\hline SCONSERVED & Units conserved \\
\hline SSOURCONSV & Source units conserved \\
\hline SSAVED & Cost savings \\
\hline TSOURCCODE & Tertiary resource identification code \\
\hline TCONSERVED & Units conserved \\
\hline TSOURCONSV & Source units conserved \\
\hline TSAVED & Cost savings \\
\hline QSOURCCODE & Quaternary resource identification code \\
\hline QCONSERVED & Units conserved \\
\hline QSOURCONSV & Source units conserved \\
\hline QSAVED & Cost savings \\
\hline REBATE & Was a rebate involved (yes/no) \\
\hline INCREMNTAL & Was the recommendation implemented incrementally (yes/no) \\
\hline FY & Fiscal Year \\
\hline IC_CAPITAL & Capital component of implementation cost \\
\hline IC_OTHER & Other component of implementation cost \\
\hline PAYBACK & Simple Payback (years) \\
\hline BPTOOL & What best practice tools was used (if any) \\
\hline
\end{tabular}




\section{Appendix B-3 Energy Source Codes and Names}

\section{Energy Source Codes and Names}

\begin{tabular}{|l|c|}
\hline \multicolumn{1}{|c|}{ PSOURCCODE } & PSOURCCODE Name \\
\hline EC & Annual kWh \\
\hline ED & Annual kW-month-year \\
\hline EF & Annual Electricity Fees \\
\hline E2 & Annual NG MMBtu \\
\hline E3 & Annual LPG MMBtu \\
\hline E4 & Annual \#1 Fuel Oil MMBtu \\
\hline E5 & Annual \#2 Fuel Oil MMBtu \\
\hline E6 & Annual \#4 Fuel Oil MMBtu \\
\hline E7 & Annual \#6 Fuel Oil MMBtu \\
\hline E8 & Annual Coal MMBtu \\
\hline E9 & Annual Wood MMBtu \\
\hline E11 & Annual Other Gas MMBtu \\
\hline E12 & Annual Other Energy MMBtu \\
\hline W0 & Annual Thousand Gallons Usage \\
\hline W1 & Annual Gallons Disposal \\
\hline W2 & Annual Other Liquid (non-haz) disposal (gal) \\
\hline W3 & Annual Other Liquid (haz) disposal (gal) \\
\hline W4 & Annual Other Solid (non-haz) disposal (lbs) \\
\hline W5 & Annual Other Solid (haz) disposal (lbs) \\
\hline W6 & Annual Gaseous Waste disposal (lbs) \\
\hline
\end{tabular}




\section{Appendix C: Survey Methodology}

\section{Appendix C-1 WVU Institutional Review Board Cover Letter}

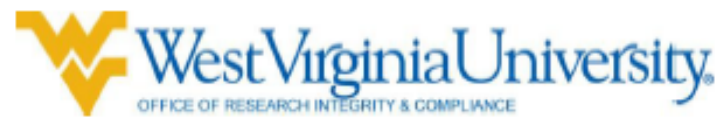

Dear Participant,

This letter is a request for you to take part in a research project to assess the effectiveness of a marketing tool to encourage business pursue energy efficiency. This project is being conducted by Challa Goutham Kumar Reddy, master's student in the Benjamin M Statler College of Engineering, with supervision of Dr. Ashish Nimbarte, an associate professor in the Benjamin M Statler College of Engineering, for a master's degree in Industrial Management and Systems Engineering. Your participation in this project is greatly appreciated and will take approximately 10 minutes to fill out the attached questionnaire.

Your involvement in this project will be kept as confidential as legally possible. All data will be reported in the aggregate. You must be 18 years of age or older to participate. I will not ask any information that should lead back to your identity as a participant. Your participation is completely voluntary. You may skip any question that you do not wish to answer and you may discontinue at any time. West Virginia University's Institutional Review Board acknowledgement of this project is on file.

I hope that you will participate in this research project, as it could be beneficial in understanding the effectiveness of a marketing tool which is used in the field of energy efficiency. Thank you very much for your time. Should you have any questions about this letter or the research project, please feel free to contact Challa Goutham at (304) 293-9478 or by e-mail at GC0021@mix.wvu.edu.

Thank you for your time and help with this project.

Sincerely,

Challa Goutham Kumar Reddy

\begin{tabular}{|c|c|}
\hline $\begin{array}{l}\text { hore: } 304-293-7079 \\
\text { Fax: 304-293-3098 }\end{array}$ & $\begin{array}{l}\text { Chestnut Ridge Research Building } \\
886 \text { Chestnut Ridge Road } \\
\text { PO Box } 6845\end{array}$ \\
\hline p://oricresearch.wnu.ed & Morgantown, WV 26506-6845 \\
\hline
\end{tabular}




\section{Instructions}

1. Please complete the attached survey form on page no. 3 .

2. Please complete step 1 before going to step 3 .

3. Please read the attached Brochure on page no. 4.

4. Please complete the attached survey form on page no. 5 .

5. Use the enclosed envelope to mail the completed survey forms (page no's 3 and 5).

Thank you, for participating in the survey. Your responses will help us serve better the energy efficiency needs of small business and industrial customers in the state of West Virginia. 


\section{Appendix C-3 Traditional Mail Packet}

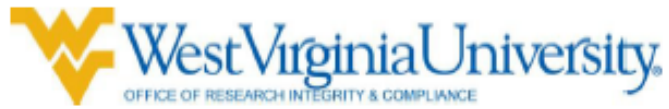

Dear Participant,

This letter is a request for you to take part in a research project to assess the effectiveness of a marketing tool to encourage business pursue energy efficiency. This project is being conducted by Challa Goutham Kumar Reddy, master's student in the Benjamin M Statler College of Engineering, with supervision of Dr. Ashish Nimbarte, an associate professor in the Benjamin M Statler College of Engineering, for a master's degree in Industrial Management and Systems Engineering. Your participation in this project is greatly appreciated and will take approximately 10 minutes to fill out the attached questionnaire.

Your involvement in this project will be kept as confidential as legally possible. All data will be reported in the aggregate. You must be 18 years of age or older to participate. I will not ask any information that should lead back to your identity as a participant. Your participation is completely voluntary. You may skip any question that you do not wish to answer and you may discontinue at any time. West Virginia University's Institutional Review Board acknowledgement of this project is on file.

I hope that you will participate in this research project, as it could be beneficial in understanding the effectiveness of a marketing tool which is used in the field of energy efficiency. Thank you very much for your time. Should you have any questions about this letter or the research project, please feel free to contact Challa Goutham at (304) 293-9478 or by e-mail at GC0021@mix.wvu.edu.

Thank you for your time and help with this project.

Sincerely,

Challa Goutham Kumar Reddy

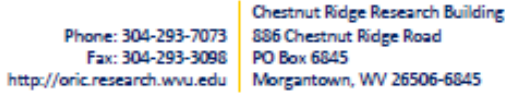

Page 1 of 5

Traditional Mail Packet Page 1 - WVU IRB Cover Letter 


\section{$\underline{\text { Instructions }}$}

1. Please complete the attached survey form on page no. 3 .

2. Please complete step 1 before going to step 3 .

3. Please read the attached Brochure on page no. 4 .

4. Please complete the attached survey form on page no. 5 .

5. Use the enclosed envelope to mail the completed survey forms (page no's 3 and 5).

Thank you, for participating in the survey. Your responses will help us serve better the energy efficiency needs of small business and industrial customers in the state of West Virginia. 


\section{Survev Questionnaire}

Please circle yes or no for the following questions

I. Are you conscious of your facilities energy usage (do you check monthly utility bills etc.)?

i) Yes

ii) No

II. Do you adjust or switch off energy equipment when not in use (Switching off lights, setback temperature etc.)?

i) Yes

ii) No

III Did you think about replacing your equipment (e.g. old water heater etc.) with energy efficient ones in the recent times?

i) Yes

ii) No

IV. Do you want to get an energy audit done at your facility now or in the near future?

i) Yes

ii) No

If yes for question IV, please answer following questions

iii) Do you have any difficulties regarding?

(1) Technological Assistance

(a) Yes

(b) No

(2) Funding Assistance

(a) Yes

(b) No

Traditional Mail Packet Page 3 - Pre-Survey Questionnaire 


\section{West Virginia Agricultural and Rural Small Business Energy Audit Program SPONSORED BY U.S. DEPARTMENT OF AGRICULTURE (USDA)}

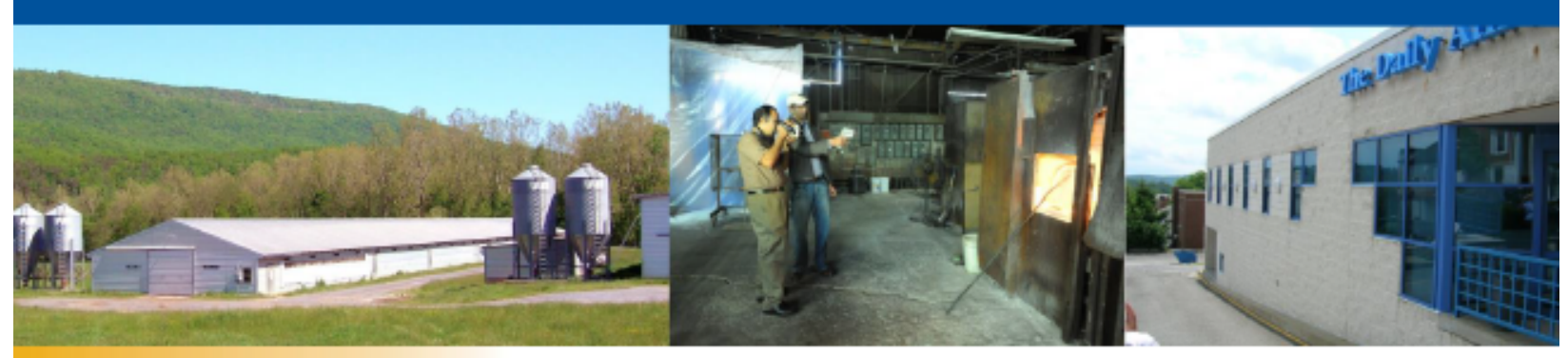

\section{Contacts}

Dr. Ashish D Nimbarte Principal Investigator Asst. Director WVU IAC (304) 293-9473 Ashish.Nimbartea mail.wru.edu

Dr. Bhaskaran

Gopalakrishnan

Director WVU IAC

(304) 293-9434

Bhaskaran.Gonalakrishnan@e mail.wvunedy

Xavier S. Walter

Director - Energy Efficient West Virginia

Cell 609-504-2119

www.eewv.org

Jesse E. Gandee

Rural Business Specialist Rural Development

U.S. Department of Agriculture (304) 284-4882

Jesse,Gandeefowr.usda.gov

WWestVirginiaUniversity.

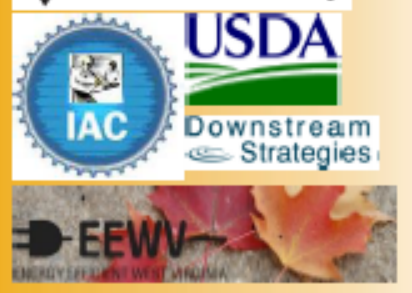

The objective is to implement a state-wide energy audit program to assist agricultural producers and rural small businesses reduce energy costs. The project team will conduct energy audits specifically developed for agricultural producers and rural small businesses in West Virginia.

Audit costs: As a participant in this program the client is only expected to pay $\$ 125$ for a full energy audit of their facility and will receive a comprehensive energy audit report. This type of audit normally averages around $\$ 3,000$ but funding from the USDA covers the majority of the cost.

Eligibility: Rural agricultural producers and for-profit small business are eligible to receive energy audit through this program. A for-profit small business is defined as any business that employs less than 500 people in a designated rural area and makes under a certain revenue based upon the type of business.

For your eligibility questions please contact Kyle Gillis.
Benefits: Our energy audit recommendations can help save from 5 to $10 \%$ of energy costs in areas of lighting, HVAC and building envelope thermographic analysis per year. The analysis of high energy consuming processes could result in even higher cost saving recommendations.

Using the energy audit report, the clients can apply for financial assistance through USDA-REAP grants and guaranteed loans programs. The grants range from $\$ 1,500$ to $\$ 250,000$, and cannot exceed $25 \%$ of total project costs. The maximum guaranteed loan is $\$ 25$ million, which may not exceed $75 \%$ of total project costs.

If you have any questions or are interested in scheduling an audit please contact:

Kyle Gillis

Phone: (304)780-2391

Email: ksgillis@mix.wvu.edu

Visit us at

http://www.wvusdareap.com/ 


\section{Please circle yes or no for the following question}

Did your response to question no. 4 on page no. 3 changed after reading the attached brochure?

i) Yes

ii) No

If yes for the above question, please answer following question

I. Do you want to get an energy audit done at your facility now or in the near future?

i) Yes

ii) No

\section{Traditional Mail Packet Page 5 - Post Survey Questionnaire}




\section{Appendix C-4 Virtual Mail Packet}

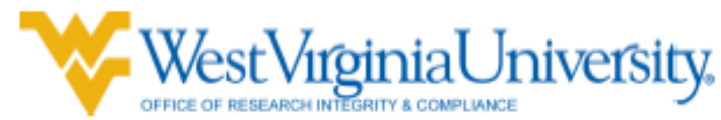

Dear Participant,

This letter is a request for you to take part in a research project to assess the effectiveness of a marketing tool to encourage business pursue energy efficiency. This project is being conducted by Challa Goutham Kumar Reddy, master's student in the Benjamin M Statler College of Engineering, with supervision of Dr. Ashish Nimbarte, an associate professor in the Benjamin M Statler College of Engineering, for a master's degree in Industrial Management and Systems Engineering. Your participation in this project is greatly appreciated and will take approximately 10 minutes to fill out the attached questionnaire.

Your involvement in this project will be kept as confidential as legally possible. All data will be reported in the aggregate. You must be 18 years of age or older to participate. I will not ask any information that should lead back to your identity as a participant. Your participation is completely voluntary. You may skip any question that you do not wish to answer and you may discontinue at any time. West Virginia University's Institutional Review Board acknowledgement of this project is on file.

I hope that you will participate in this research project, as it could be beneficial in understanding the effectiveness of a marketing tool which is used in the field of energy efficiency. Thank you very much for your time. Should you have any questions about this letter or the research project, please feel free to contact Challa Goutham at (304) 293-9478 or by e-mail at GC0021@mix.uvu.edu.

Thank you for your time and help with this project.

Sincerely,

Challa Goutham Kumar Reddy

\section{Virtual Mail Packet Page 1 - WVU IRB Cover Letter}




\section{$\underline{\text { Instructions }}$}

1. Please complete the attached survey form on page no. 3.

2. Please complete step 1 before going to step 3 .

3. Please read the attached Brochures on page no. 4 and page no. 5 .

4. Please complete the attached survey form on page no. 6 .

5. Use the enclosed envelope to mail the completed survey forms.

Thank you, for participating in the survey. Your responses will help us serve better the energy efficiency needs of small business and industrial customers in the state of West Virginia. 


\section{Survey Questionnaire}

Please circle yes or no for the following questions

I. Are you conscious of your facilities energy usage (do you check monthly utility bills etc.)?
i) Yes
ii) No

II. Do you adjust or switch off energy equipment when not in use (Switching off lights, setback temperature etc.)?
i) Yes

ii) No

III Did you think about replacing your equipment (e.g. old water heater etc.) with energy efficient ones in the recent times?

i) Yes

ii) No

IV. Do you want to get an energy audit done at your facility now or in the near future?

i) Yes

ii) No

If yes for question IV, please answer following questions

iii) Do you have any difficulties regarding?

(1) Technological Assistance
(a) Yes
(b) No

(2) Funding Assistance

(a) Yes

(b) No

\section{Virtual Mail Packet Page 3 - Pre-Survey Questionnaire}




\section{Dear Business Owner:}

Our team at WVU has performed a virtual energy audit for your business, Here are some key findings

- Based on energy per sq. $\mathrm{ft}$ it is estimated that your facility consumes 5119068 kWh/yr and $6662 \mathrm{MMBtu} / \mathrm{yr}$.

\section{Facilities Image}

- Your facility can save around \$21121per year in energy costs by implementing the energy efficient technologies ( see table below for additional information)

\section{Potential Energy Saving Opportunites}

\begin{tabular}{|c|c|c|c|c|c|c|c|}
\hline S.No & Energy Systems & Possible Recommendation & & $\begin{array}{l}\text { Current } \\
\text { lergy Costs } \\
(\$ / y r)\end{array}$ & $\begin{array}{l}P \\
\text { Ene }\end{array}$ & $\begin{array}{l}\text { roposed } \\
\text { rgy Costs } \\
(\$ / y r)\end{array}$ & $\begin{array}{l}\text { Savings } \\
\text { (\$/yr) }\end{array}$ \\
\hline 1 & Motor Systems & $\begin{array}{l}\text { Establish Replace/Rewind Policy for } \\
\text { Motors, Use of VFD's on Motors \& } \\
\text { Pumps, Compressor Controls, Sequencer } \\
\text { etc. }\end{array}$ & $\$$ & 90,479 & $\$$ & 82,234 & $\$ 8,245$ \\
\hline 2 & $\begin{array}{l}\text { Combustion and } \\
\text { Thermal } \\
\text { Systems }\end{array}$ & $\begin{array}{l}\text { Recover Boiler Condesnate, Flue Gas - } \\
\text { Recuperation, Air to Fuel Ratio, Insulate } \\
\text { Hot Surfaces to Avoid Heat Loss, Fix } \\
\text { steam leaks, etc. }\end{array}$ & $\$$ & 62,651 & $\$$ & 55,645 & \$ 7,006 \\
\hline 3 & $\begin{array}{l}\text { Building and } \\
\text { Grounds }\end{array}$ & $\begin{array}{l}\text { Upgrade Lighting to LED \& Install } \\
\text { Occupancy Sensors, Retrofit HVAC } \\
\text { units with Economizer, Multi-Speed } \\
\text { Supply Fan, Demand-Controlled } \\
\text { Ventilation [DCV] etc. }\end{array}$ & $\$$ & 58,911 & $\$$ & 53,041 & \$ 5,870 \\
\hline Total & - & - & $\$$ & 212,041 & $\$$ & 190,920 & \$ 21,121 \\
\hline
\end{tabular}

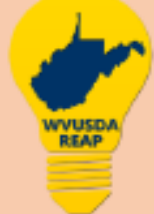

We can make your business energy efficient, Please visit us at https://industrialassessmentcenter.wvu.edu/ 


\title{
West Virginia Agricultural and Rural Small Business Energy Audit
} Program

\author{
SPONSORED BY U.S. DEPARTMENT OF AGRICULTURE (USDA)
}

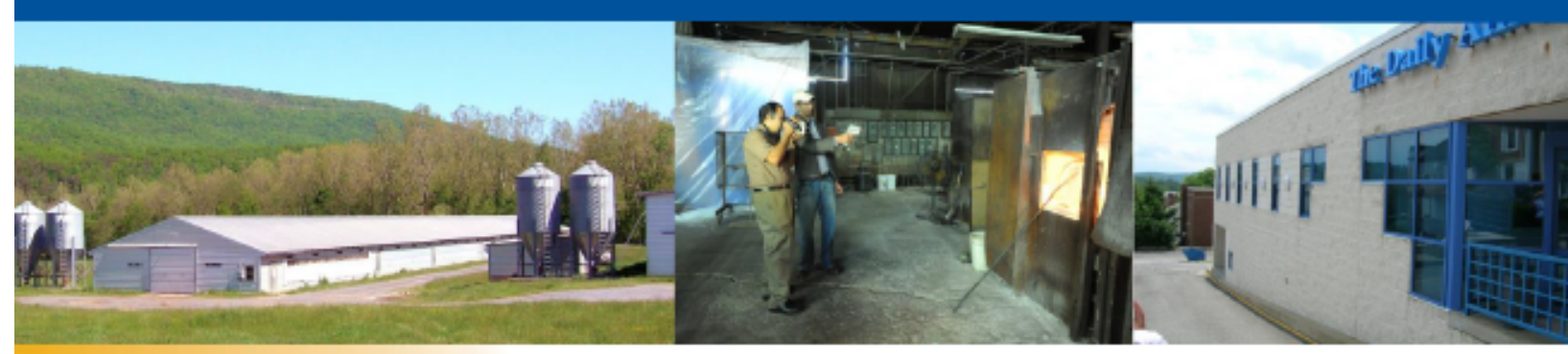

\section{Contacts}

Dr. Ashish D Nimbarte Principal Investigator Asst. Director WVU IAC (304) 293-9473 Ashish.Nimbarte. mail.wvu.edu

Dr. Bhaskaran Gopalakrishnan Director WVU IAC (304) 293-9434 Bhaskaran.Gopalakrishnan@e. mail.wyuedu

Xavier S. Walter Director - Energy Efficient West Virginia

Cell 609-504-2119 www.eewv.org

Jesse E. Gandee

Rural Business Specialist Rural Development

U.S. Department of Agriculture (304) 284-4882 Jesse,Gandeefowy.usdangoy

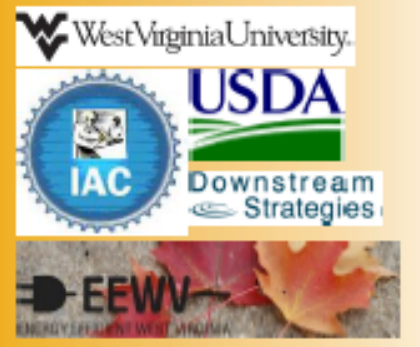

The objective is to implement a state-wide energy audit program to assist agricultural producers and rural small businesses reduce energy costs. The project team will conduct energy audits specifically developed for agricultural producers and rural small businesses in West Virginia.

Audit costs: As a participant in this program the client is only expected to pay $\$ 125$ for a full energy audit of their facility and will receive a comprehensive energy audit report. This type of audit normally averages around $\$ 3,000$ but funding from the USDA covers the majority of the cost.

Eligibility: Rural agricultural producers and for-profit small business are eligible to receive energy audit through this program. A for-profit small business is defined as any business that employs less than 500 people in a designated rural area and makes under a certain revenue based upon the type of business.

For your eligibility questions please contact Kyle Gillis.
Benefits: Our energy audit recommendations can help save from 5 to $10 \%$ of energy costs in areas of lighting, HVAC and building envelope thermographic analysis per year. The analysis of high energy consuming processes could result in even higher cost saving recommendations.

Using the energy audit report, the clients can apply for financial assistance through USDA-REAP grants and guaranteed loans programs. The grants range from $\$ 1,500$ to $\$ 250,000$, and cannot exceed $25 \%$ of total project costs. The maximum guaranteed loan is $\$ 25$ million, which may not exceed $75 \%$ of total project costs.

If you have any questions or are interested in scheduling an audit please contact:

\section{Kyle Gillis}

Phone: (304)780-2391

Email: ksgillis@mix.wvu.edu

Visit us at

http://www.wvusdareap.com/ 


\section{Please circle yes or no for the following question}

Did your response to question no. 4 on page no. 3 changed after reading the attached brochure?

i) Yes

ii) No

If yes for the above question, please answer following question

I. Do you want to get an energy audit done at your facility now or in the near future?

i) Yes

ii) No 


\section{Appendix C-5 Survey Response Table}

Survey Response Table

\begin{tabular}{|c|c|c|c|c|c|c|}
\hline \multirow{2}{*}{ S. No. } & \multirow{2}{*}{ Survey Type } & \multicolumn{4}{|c|}{ Before Reading the Brochure } & \multirow{2}{*}{$\begin{array}{c}\text { After Reading the Brochure } \\
\text { Q5 }\end{array}$} \\
\hline & & Q1 & Q2 & Q3 & Q4 & \\
\hline 1 & Virtual & Yes & Yes & Yes & Yes & No \\
\hline 2 & Virtual & No & Yes & Yes & No & No \\
\hline 3 & Virtual & Yes & Yes & No & No & Yes \\
\hline 4 & Virtual & Yes & Yes & Yes & No & Yes \\
\hline 5 & Virtual & Yes & Yes & No & No & Yes \\
\hline 6 & Virtual & Yes & Yes & Yes & No & No \\
\hline 7 & Traditional & Yes & Yes & Yes & No & No \\
\hline 8 & Traditional & Yes & Yes & No & No & No \\
\hline 9 & Traditional & Yes & Yes & Yes & No & Yes \\
\hline 10 & Traditional & Yes & Yes & Yes & No & No \\
\hline 11 & Traditional & Yes & Yes & Yes & No & Yes \\
\hline 12 & Traditional & Yes & Yes & Yes & No & No \\
\hline 13 & Traditional & Yes & Yes & Yes & No & No \\
\hline 14 & Traditional & Yes & Yes & Yes & No & No \\
\hline 15 & Traditional & Yes & Yes & Yes & No & Yes \\
\hline 16 & Traditional & Yes & Yes & Yes & Yes & No \\
\hline 17 & Virtual & Yes & No & Yes & No & No \\
\hline 18 & Virtual & Yes & Yes & Yes & No & No \\
\hline 19 & Traditional & Yes & Yes & Yes & No & No \\
\hline 20 & Virtual & Yes & Yes & Yes & Yes & No \\
\hline
\end{tabular}

